\title{
Simulation of Multiscale Ground-Water Flow in Part of the Northeastern San Joaquin Valley, California
}

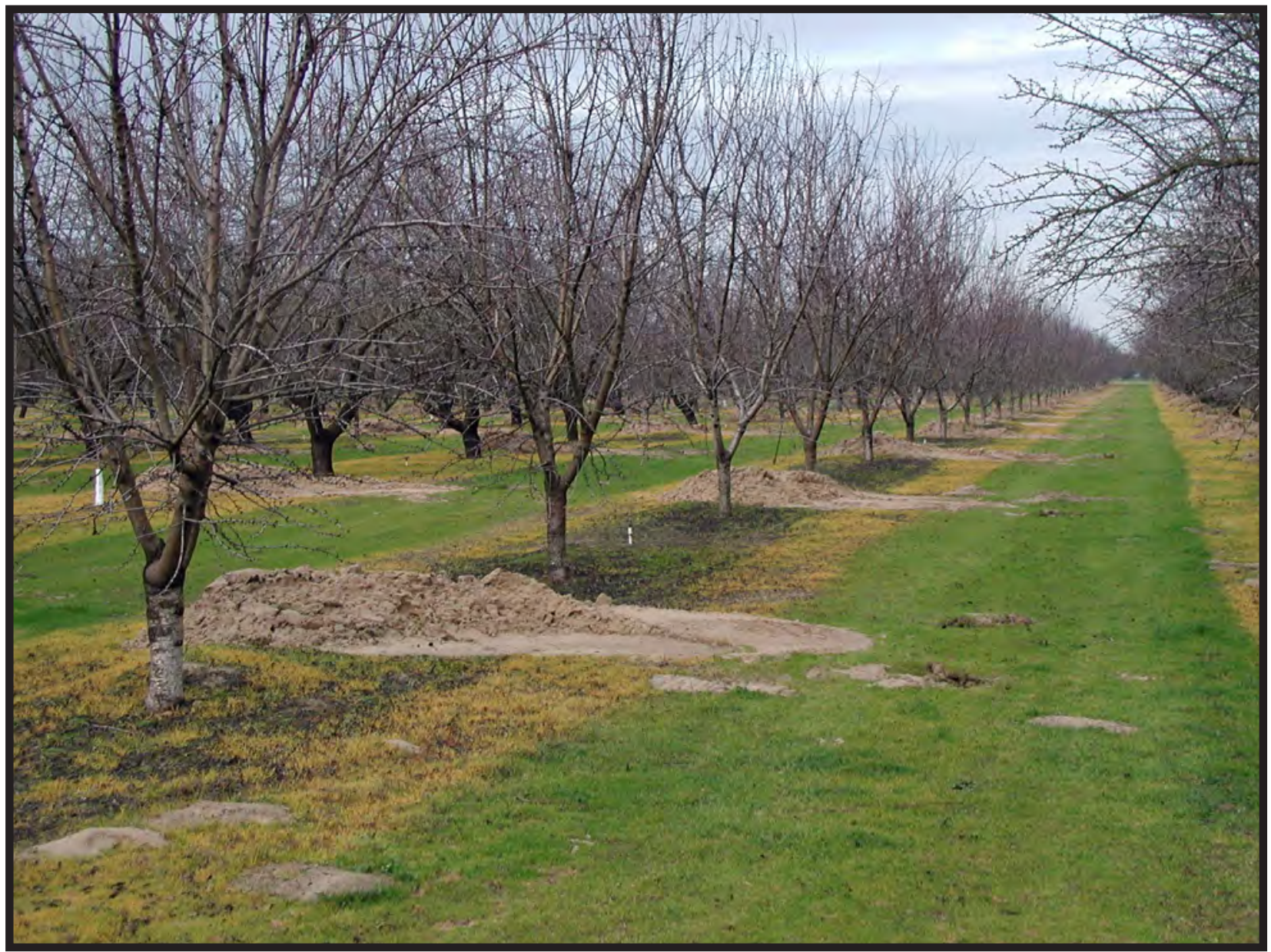

SIR 2007-5009 
Cover: Olive orchard near the Merced River, California. Joe Domagalski, U.S. Geological Survey. 


\section{Simulation of Multiscale Ground-Water Flow in Part of the Northeastern San Joaquin Valley, California}

By Steven P. Phillips, Christopher T. Green, Karen R. Burow, Jennifer L. Shelton, and Diane L. Rewis

Scientific Investigations Report 2007-5009 


\section{U.S. Department of the Interior DIRK A. KEMPTHORNE, Secretary \\ U.S. Geological Survey \\ Mark D. Myers, Director}

\section{U.S. Geological Survey, Reston, Virginia: 2007}

For product and ordering information:

World Wide Web: http://www.usgs.gov/pubprod

Telephone: 1-888-ASK-USGS

For more information on the USGS--the Federal source for science about the Earth, its natural and living resources, natural hazards, and the environment:

World Wide Web: http://www.usgs.gov

Telephone: 1-888-ASK-USGS

Any use of trade, product, or firm names is for descriptive purposes only and does not imply endorsement by the U.S. Government.

Although this report is in the public domain, permission must be secured from the individual copyright owners to reproduce any copyrighted materials contained within this report.

Suggested reference:

Phillips, S.P., Green, C.T., Burow, K.R., Shelton, J.L., and Rewis, D.L., 2007, Simulation of multiscale ground-water flow in part of the northeastern San Joaquin Valley, California: U.S. Geological Survey Scientific Investigations Report 2007-5009, 43 p. 


\section{Contents}

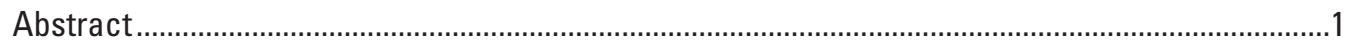

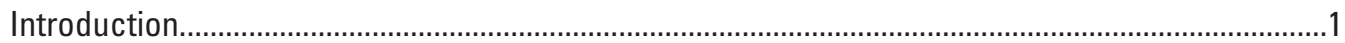

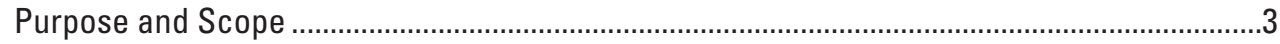

Study Area Descriptions ......................................................................................................

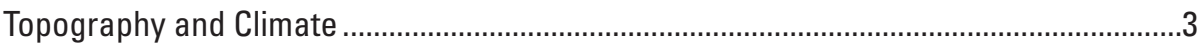

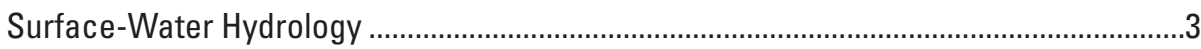

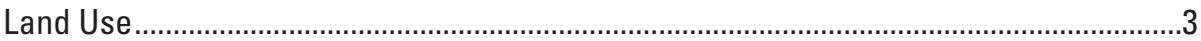

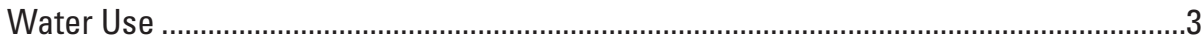

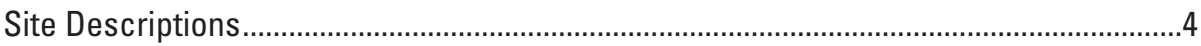

Conceptual Understanding of Ground-Water System .................................................................

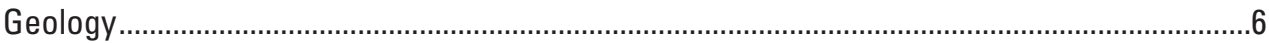

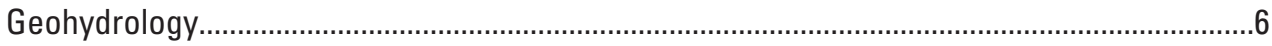

Aquifer Hydraulic Properties ....................................................................................

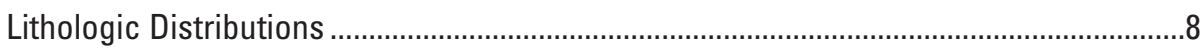

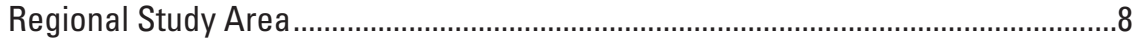

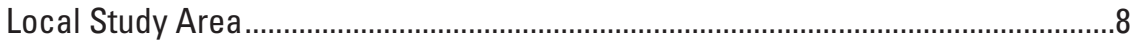

Ground-Water Occurrence and Movement ..................................................................... 10

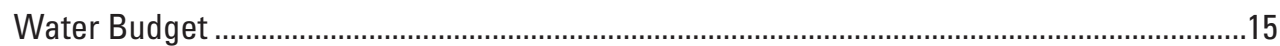

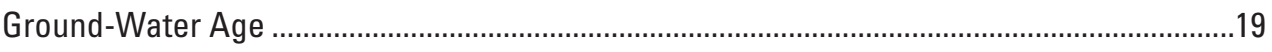

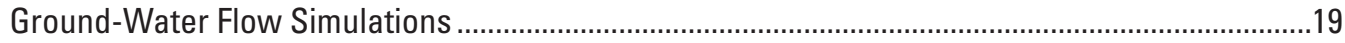

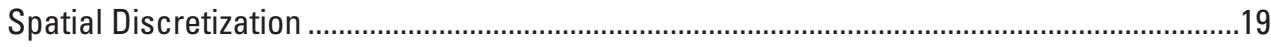

Regional Model ...................................................................................................... 19

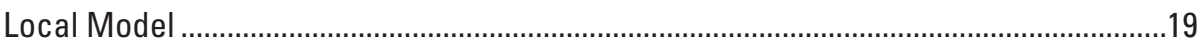

Boundary Conditions and Model Stresses ............................................................................23

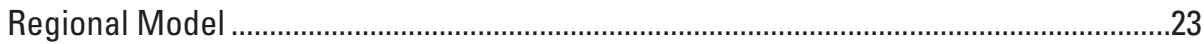

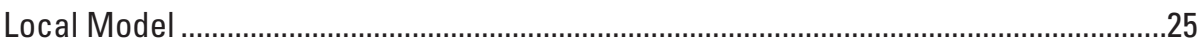

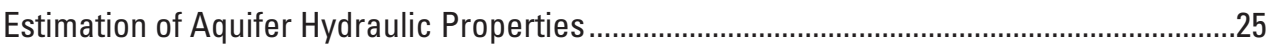

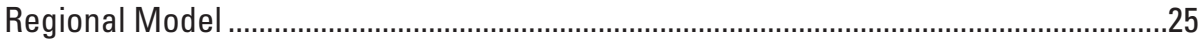

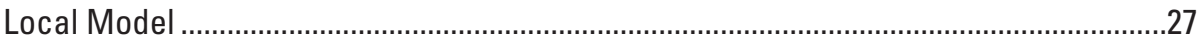

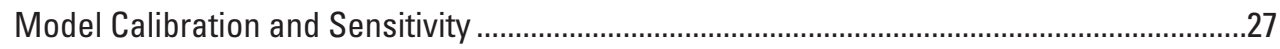

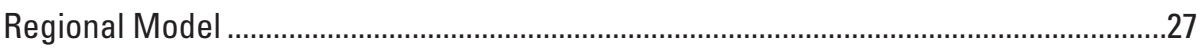

Regional Simulated Hydraulic Heads ......................................................................

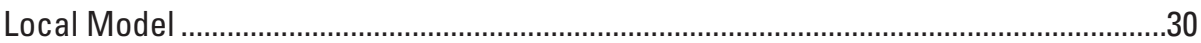

Local Simulated Hydraulic Heads ............................................................................33

Evaluation of Fluxes in Local Model ............................................................................34

Sensitivity of Local Model Parameter Estimates to Hydrofacies Distribution and Recharge ..........................................................................35

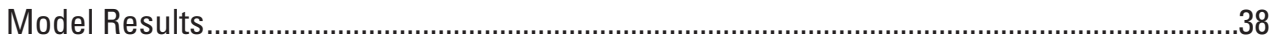

Limitations and Appropriate Use of the Models .....................................................................

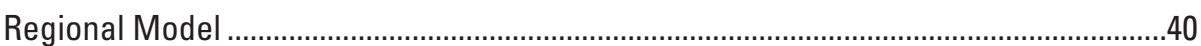

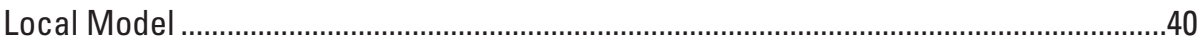

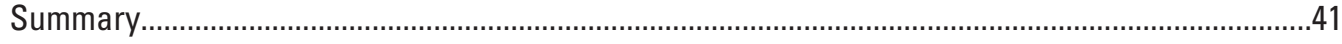

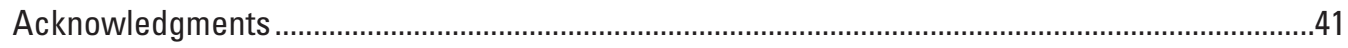

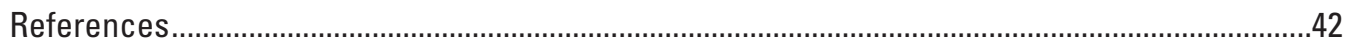




\section{Figures}

Figure 1. Locations of San Joaquin regional and local study areas within the Central Valley, California

Figure 2. Land use and description of U.S. Geological Survey (USGS) wells in Modesto, San Joaquin regional study area, California

Figure 3. Land use and description of U.S. Geological Survey (USGS) transect wells, San Joaquin local study area, California 5

Figure 4. Selected geologic units, San Joaquin regional study area, California $\ldots \ldots \ldots \ldots \ldots .7$

Figure 5. Two-dimensional slices through three-dimensional model of percentage coarse-grained sediments, San Joaquin regional study area, California ........... 9

Figure 6. Vertical transition probabilities used to constrain vertical sequences of hydrofacies, San Joaquin local study area, California

Figure 7. Conceptual diagram of $(A)$ regional lateral ground-water flow and $(B)$ vertical flow influenced by agricultural practices and natural discharge zones $\quad \ldots \ldots \ldots \ldots 13$

Figure 8. Contours of measured water-level altitudes in the unconfined to semiconfined aquifer, spring 2000, San Joaquin regional study area, California ....

Figure 9. Hydrographs of measured water-level altitudes for selected irrigation wells from 1960 to 2001, San Joaquin regional study area, California

Figure 10. Hydrographs of water-level altitudes measured hourly in U.S. Geological Survey monitoring wells in urban Modesto from December 2003 to July 2005, San Joaquin regional study area, California

Figure 11. Hydrographs of water-level altitudes measured hourly in U.S. Geological Survey monitoring-well transect from June 2003 to May 2005, San Joaquin local study area, California

Figure 12. Subareas of regional model used for water-budget calculations, San Joaquin regional study area, California

Figure 13. Estimated rates of recharge for subareas of regional model, water year 2000, San Joaquin regional study area, California.

Figure 14. Estimated rates of ground-water pumping for subareas of regional model, water year 2000, San Joaquin regional study area, California

Figure 15. Model extent, boundary conditions, and extent of the downslope, midslope, and upslope areas for the regional model, San Joaquin regional study area, California

Figure 16. Vertical discretization of regional model along row 73, San Joaquin regional study area, California

Figure 17. Extent of active area and boundary conditions for the local model, San Joaquin local study area, California

Figure 18. Estimated rates of recharge for the local model, water year 2000, San Joaquin local study area, California

Figure 19. Frequency of estimated horizontal and vertical hydraulic conductivity for the upslope (eastern) and downslope (western) alluvial deposits, San Joaquin regional study area, California

Figure 20. Vertical section roughly parallel to the Merced River showing distribution of hydrofacies used in calibrated local model, San Joaquin local study area, California

Figure 21. Error surfaces used to calibrate, and calibration results for, the regional model, San Joaquin regional study area, California

Figure 22. Simulated hydraulic heads at the water table and in layer 9 , and errors between measured water levels and simulated hydraulic heads at wells used to calibrate the regional model, San Joaquin regional study area, California 
Figure 23. Relation between simulated hydraulic head and measured water levels for regional model, San Joaquin regional study area, California

Figure 24. Relative composite sensitivity of computed hydraulic head at calibration points to changes in the horizontal and vertical hydraulic conductivities of the defined hydrofacies, local model, San Joaquin local study area, California

Figure 25. Relative sensitivity of computed hydraulic head at calibration points to changes in hydraulic parameters, local model, San Joaquin local study area, California ... 35

Figure 26. Relation between simulated hydraulic head and measured water levels for the

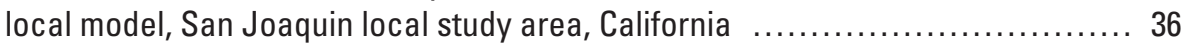

Figure 27. Simulated water-table altitudes for the local model, San Joaquin local study area, California

\section{Tables}

Table 1. Proportions and mean lengths of hydrofacies used in local model, San Joaquin

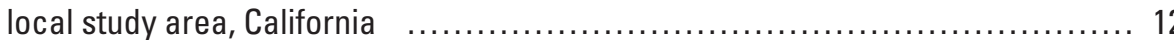

Table 2. Soft-conditioning probabilities assigned to hydrofacies for non-U.S. Geological Survey well log descriptions, San Joaquin local study area, California $\ldots \ldots \ldots \ldots .12$

Table 3. Calibrated and specified hydraulic conductivity values for the local model, San Joaquin local study area, California

Table 4. Measured concentrations of sulfur hexafluoride $\left(\mathrm{SF}_{6}\right)$ along the U.S. Geological Survey well transect and concentrations estimated using simulated travel time and historical atmospheric concentrations of $\mathrm{SF}_{6^{\prime}}$ San Joaquin local study area, California

Table 5. Changes in key hydraulic conductivity parameters with alternate threedimensional distributions of hydrofacies in the local model, San Joaquin local study area, California

Table 6. Simulated water budget for the regional model, San Joaquin regional study area, California

Table 7. Simulated water budget for the local model, San Joaquin local study area, California 


\section{Datums Used}

Vertical coordinate information is referenced to the North American Vertical Datum of 1988 (NAVD 88).

Horizontal coordinate information is referenced to the North American Datum of 1983 (NAD 83).

Elevation, as used in this report, refers to distance above the vertical datum.

$\mathrm{km}$, kilometer

$\mathrm{km}^{2}$, square kilometer

m, meter

$\mathrm{m} / \mathrm{d}$, meter per day

$\mathrm{m} / \mathrm{km}$, meter per kilometer

$\mathrm{m} / \mathrm{yr}$, meter per year

$\mathrm{m}^{3} / \mathrm{d}$, cubic meter per day

$\mathrm{mg} / \mathrm{L}$, milligram per liter

$\mathrm{mm}$, millimeter

pptv, parts per trillion by volume

$K_{\text {coarse }}$, coarse-grained lithologic end member

$K_{\text {corc }}$, Corcoran Clay

$K_{\text {fine }}$, hydraulic conductivity of fine-grained lithologic end member

$K_{h}$, horizontal hydraulic conductivity

$K_{v}$, vertical hydraulic conductivity between model layers

NAWQA, National Water-Quality Assessment

$\mathrm{SF}_{6^{\prime}}$ sulfur hexafluoride

TProGS, Transition-Probability Geostatistical Software

RMSE, root mean square error

SANJ, San Joaquin-Tulare Basins study unit of NAWQA

USGS, U.S. Geological Survey 


\section{Well-Numbering System}

Wells are identified and numbered according to their location in the rectangular system for the subdivision of public lands. Identification consists of the township number, north or south; the range number, east or west; and the section number. Each section is divided into sixteen 40 -acre tracts lettered consecutively (except I and 0 ), beginning with " $\mathrm{A}$ " in the northeast corner of the section and progressing in a sinusoidal manner to " $\mathrm{R}$ " in the southeast corner. Within the 40 -acre tract, wells are sequentially numbered in the order they are inventoried. The final letter refers to the base line and meridian. In California, there are three base lines and meridians; Humboldt (H), Mount Diablo (M), and San Bernardino (S). All wells in the study area are referenced to the Mount Diablo base line and meridian. Well numbers consist of 15 characters and follow the format 003S007E13A001. In this report, well numbers are abbreviated and written 3S/7E-13A1. The following diagram shows how the number for well $3 \mathrm{~S} / 7 \mathrm{E}-13 \mathrm{~A} 1$ is derived.

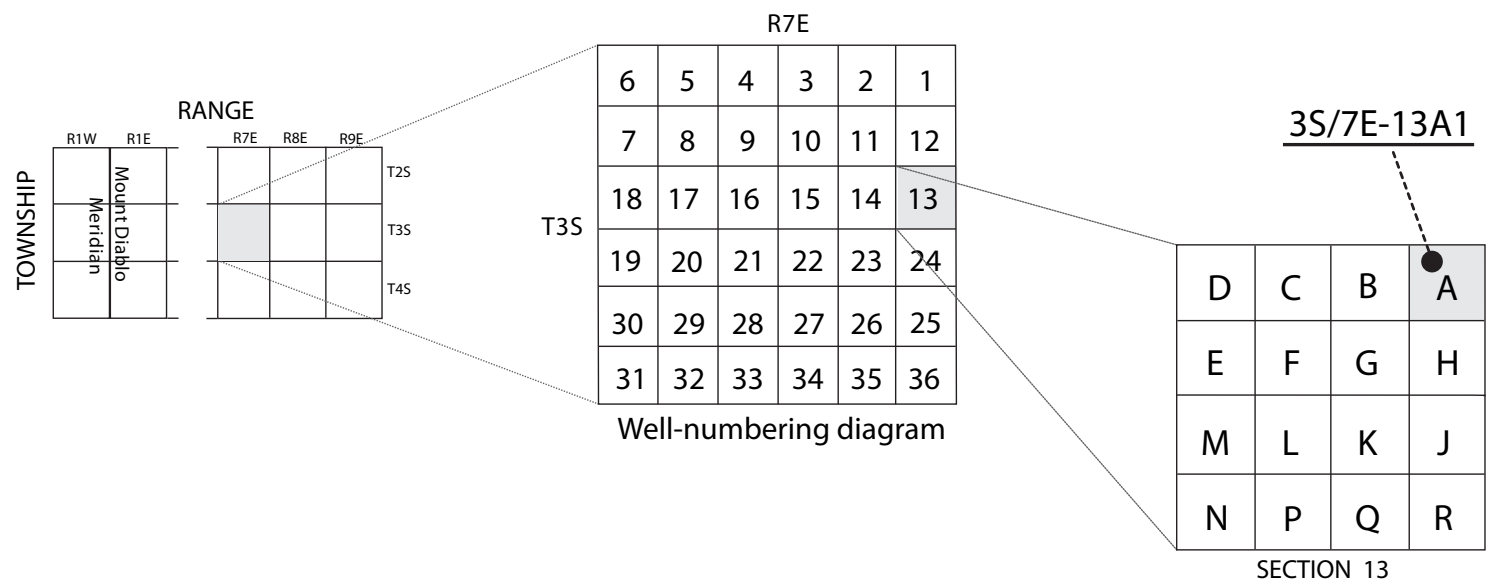


This page intentionlly left blank. 


\title{
Simulation of Multiscale Ground-Water Flow in Part of the Northeastern San Joaquin Valley, California
}

\author{
By Steven P. Phillips, Christopher T. Green, Karen R. Burow, Jennifer L. Shelton, and Diane L. Rewis
}

\section{Abstract}

The transport and fate of agricultural chemicals in a variety of environmental settings is being evaluated as part of the U.S. Geological Survey (USGS) National Water-Quality Assessment Program. One of the locations being evaluated is a $2,700-\mathrm{km}^{2}$ (square kilometer) regional study area in the northeastern San Joaquin Valley surrounding the city of Modesto, an area dominated by irrigated agriculture in a semi-arid climate. Ground water is a key source of water for irrigation and public supply, and exploitation of this resource has altered the natural flow system. The aquifer system is predominantly alluvial, and an unconfined to semiconfined aquifer overlies a confined aquifer in the southwestern part of the study area; these aquifers are separated by the lacustrine Corcoran Clay. A regional-scale 16-layer steady-state model of ground-water flow in the aquifer system in the regional study area was developed to provide boundary conditions for an embedded 110-layer steady-state local-scale model of part of the aquifer system overlying the Corcoran Clay along the Merced River. The purpose of the local-scale model was to develop a better understanding of the aquifer system and to provide a basis for simulation of reactive transport of agricultural chemicals.

The heterogeneity of aquifer materials was explicitly incorporated into the regional and local models using information from geologic and drillers' logs of boreholes. Aquifer materials were differentiated in the regional model by the percentage of coarse-grained sediments in a cell, and in the local model by four hydrofacies (sand, silty sand, silt, and clay). The calibrated horizontal hydraulic conductivity values of the coarse-grained materials in the zone above the Corcoran Clay in the regional model and of the sand hydrofacies used in the local model were about equal (30-80 m/d [meter per day]), and the vertical hydraulic conductivity values in the same zone of the regional model (median of $0.012 \mathrm{~m} / \mathrm{d}$ ), which is dominated by the finer-grained materials, were about an order of magnitude less than that for the clay hydrofacies in the local model.
Data used for calibrating both models included long-term hourly water-level measurements in 20 short-screened wells installed by the USGS in the Modesto and Merced River areas. Additional calibration data for the regional model included water-level measurements in 11 wells upslope and 17 wells downslope from these areas. The root mean square error was $2.3 \mathrm{~m}$ (meter) for all wells in the regional model and $0.8 \mathrm{~m}$ for only the USGS wells; the associated average errors were $0.9 \mathrm{~m}$ and $0.3 \mathrm{~m}$, respectively. The root mean square error for the 12 USGS wells along a transect in the local model area was $0.08 \mathrm{~m}$; the average error was $0.0 \mathrm{~m}$. Particle tracking was used with the local model to estimate the concentration of an environmental tracer, sulfur hexafluoride, in 10 USGS transect wells near the Merced River that were sampled for this constituent. Measured and estimated concentrations in the mid-depth and deepest wells, which would be most sensitive to errors in hydraulic conductivity estimates, were consistent. The combined results of particle tracking and sulfur hexafluoride analysis suggest that most water sampled from the transect wells was recharged less that 25 years ago.

\section{Introduction}

The U.S. Geological Survey (USGS) National WaterQuality Assessment (NAWQA) Program is studying the transport and fate of agricultural chemicals in a variety of hydrologic and agricultural settings across the nation. The agricultural chemicals studied include those associated with applied fertilizers, herbicides, and pesticides. One of these settings is in the northeastern San Joaquin Valley near Modesto, California (fig. 1). The regional-scale study area straddled the valley floor and the local-scale study area was focused on a small area along the Merced River south of Turlock (fig. 1). These study areas are hereinafter referred to as "regional" and "local." 

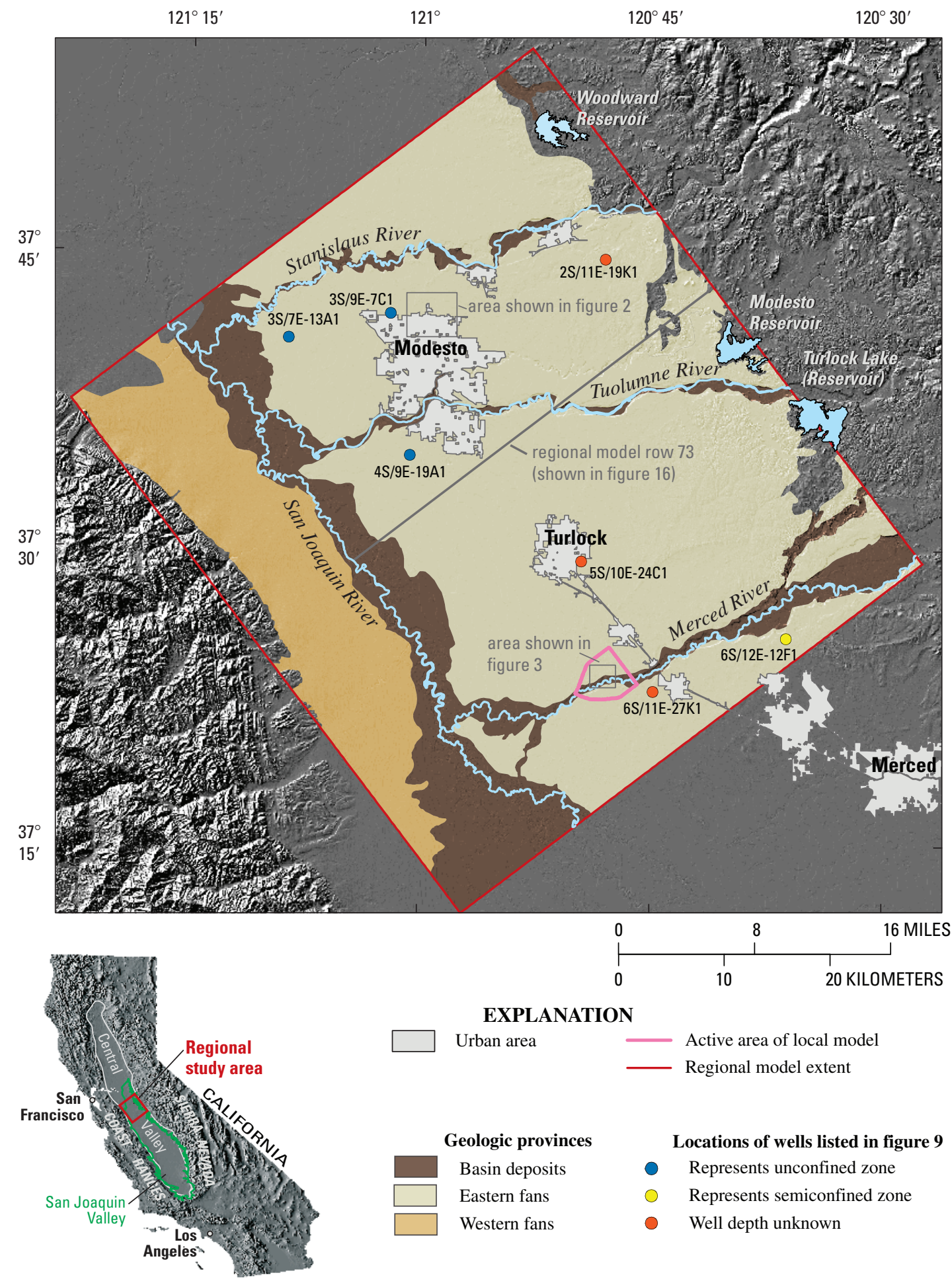

\section{EXPLANATION}

Urban area $\quad$ Active area of local model

- Regional model extent

Geologic provinces $\quad$ Locations of wells listed in figure 9

Basin deposits $\quad$ Represents unconfined zone

Eastern fans $\quad \bigcirc \quad$ Represents semiconfined zone

Western fans $\quad$ Well depth unknown

Figure 1. Locations of San Joaquin regional and local study areas within the Central Valley, California. 


\section{Purpose and Scope}

The purpose of this report is to summarize the hydrologic settings of the regional and local study areas and document the development and calibration of steady-state regional and local ground-water flow models. These models support future simulations and analyses of chemical mass balance, transport, and fate. Additional information on the regional hydrologic setting can be found in Burow and others (2004) and Gronberg and Kratzer (2006). The model described in this report is an updated version of the model described by Phillips and others (in press).

\section{Study Area Descriptions}

The San Joaquin Valley is more than $400 \mathrm{~km}$ long, 40 to $90 \mathrm{~km}$ wide, and occupies the southern two-thirds of the Central Valley of California (fig. 1). The valley floor is underlain by a structural trough filled with marine and continental sediments up to $10 \mathrm{~km}$ thick (Gronberg and others, 1998). The Sierra Nevada rise east of the valley to an altitude of more than 4,200 m; the Coast Ranges, having moderate altitude, form the western edge of the valley. The San Joaquin River drains the northern part of the San Joaquin Valley through San Francisco Bay; the southern part of the valley is a hydrologically closed basin.

The regional study area is about $2,700 \mathrm{~km}^{2}$ in the northeastern San Joaquin Valley, bounded on the west by the San Joaquin River, on the north near the Stanislaus River, on the south near the Merced River, and on the east by the Sierra Nevada foothills (fig. 1). Within the regional bounds is the local study area, about $17 \mathrm{~km}^{2}$, located south of Turlock along a reach of the Merced River (fig. 1).

\section{Topography and Climate}

The land surface in the regional study area slopes westward from the Sierra Nevada foothills to the San Joaquin River; gradients range from less than $1 \mathrm{~m} / \mathrm{km}$ near the river to more than $5 \mathrm{~m} / \mathrm{km}$ in places near the foothills and adjacent to streams and rivers, including the local study area (fig. 1). The climate is semi-arid, characterized by hot summers and mild winters; the rainfall averaged $315 \mathrm{~mm}$ annually from 1931 to 1997 during late fall through early spring (National Oceanic and Atmospheric Administration, 2005).

\section{Surface-Water Hydrology}

The San Joaquin River is the central drainage for the northern San Joaquin Valley and is the only major surfacewater outlet from the valley. The Stanislaus, Tuolumne, and Merced Rivers drain the Sierra Nevada and are tributaries to the San Joaquin River. All rivers in the study area have been significantly modified from their natural state. Each has multiple reservoirs for irrigation and power generation, which effectively delay discharge of large amounts of snowmelt runoff. An extensive network of canals is used to deliver water for irrigation.

\section{Land Use}

Agriculture is the primary land use, covering about 65 percent of the regional study area and about 80 percent of the local study area. The primary crops in the regional study area are almonds, walnuts, peaches, grapes, grain, corn, pasture, and alfalfa. Modesto, Turlock, and a number of smaller urban areas covered about 6 percent of the regional study area in 2000. The remaining area was predominantly natural vegetation near the foothills and in riparian areas (California Department of Water Resources, 2001a,b).

\section{Water Use}

Agricultural irrigation supplied by surface water and ground water currently accounts for about 95 percent of the total water use in the region (Burow and others, 2004). Surface-water supplies originate primarily from a series of reservoirs in the Sierra Nevada foothills. These supplies are managed by irrigation districts and delivered to agricultural users through hundreds of kilometers of lined canals.

Most irrigation districts and private agricultural users also pump ground water for irrigation; in addition, some districts pump ground water to lower the water table in areas where it has risen too close to the land surface to support agriculture without active management. Private agricultural ground-water pumpage is not measured in the regional study area but was estimated in a water-budget analysis (Burow and others, 2004) to be about 32 percent of total agricultural water use in water year 2000 (October 1, 1999, through September 30, 2000). Ground-water use is insignificant in the local study area, where most irrigation water is delivered by canal or pumped from the Merced River.

Urban water demand is met by surface-water and groundwater supplies. Before 1995, the city of Modesto, the largest urban area in the regional study area, used ground water exclusively for public supply. A surface-water treatment plant was completed in 1994, which now provides about one-half of Modesto's municipal and industrial water supplies. About 55 percent of urban water requirement was met by ground water in water year 2000 (Burow and others, 2004).

On the basis of information from local drillers' logs, about 60 percent of wells in the study area are for domestic use, followed by 27 percent for irrigation, 4 percent for public supply, and 7 percent for test, stock, industrial, and other uses (Burow and others, 2004). Well depths range from 7 to $368 \mathrm{~m}$ below land surface; the median depth is $59 \mathrm{~m}$. The median depths below land surface to the midpoints of perforated intervals in domestic, irrigation, and municipal wells are 47, 63 , and $68 \mathrm{~m}$, respectively. Fewer wells exist in the older sediments and terraces east of Modesto and Turlock and along the San Joaquin River. The deepest wells are in the older sediments in the eastern part of the regional study area, and the shallowest wells are in the western part and along the rivers. Additional clusters of deep wells are in the urban areas. 


\section{Site Descriptions}

Clusters of monitoring wells were installed by the USGS at two primary locations in the regional study area: urban Modesto and the local study area. The wells in urban Modesto were installed as part of a USGS national assessment of the vulnerability of public-supply wells to contamination from urban, agricultural, and natural sources (Eberts and others, 2005). The Modesto-area wells used in this study for model calibration and the associated land use are shown in figure 2. There are four clusters of monitoring wells consisting of 3 or 4 wells each; mid-screen depths ranged from about $10 \mathrm{~m}$ near the water table to about $100 \mathrm{~m}$. All well screens in the Modesto area were $1.5 \mathrm{~m}$. Twelve of these wells were instrumented using pressure transducers that recorded hourly waterlevel measurements for periods ranging from 1 to 2.5 years.

Clusters of monitoring wells installed in the local study area as part of this study were located at three sites along a transect (fig. 3) that is roughly oriented in the direction of ground-water flow toward the Merced River. The site at the upper end of the transect (northern, up-gradient end) was in an almond orchard. The middle site was between an upslope almond orchard and a corn field (feed corn), and the site at the lower end was in native vegetation at the edge of the riparian

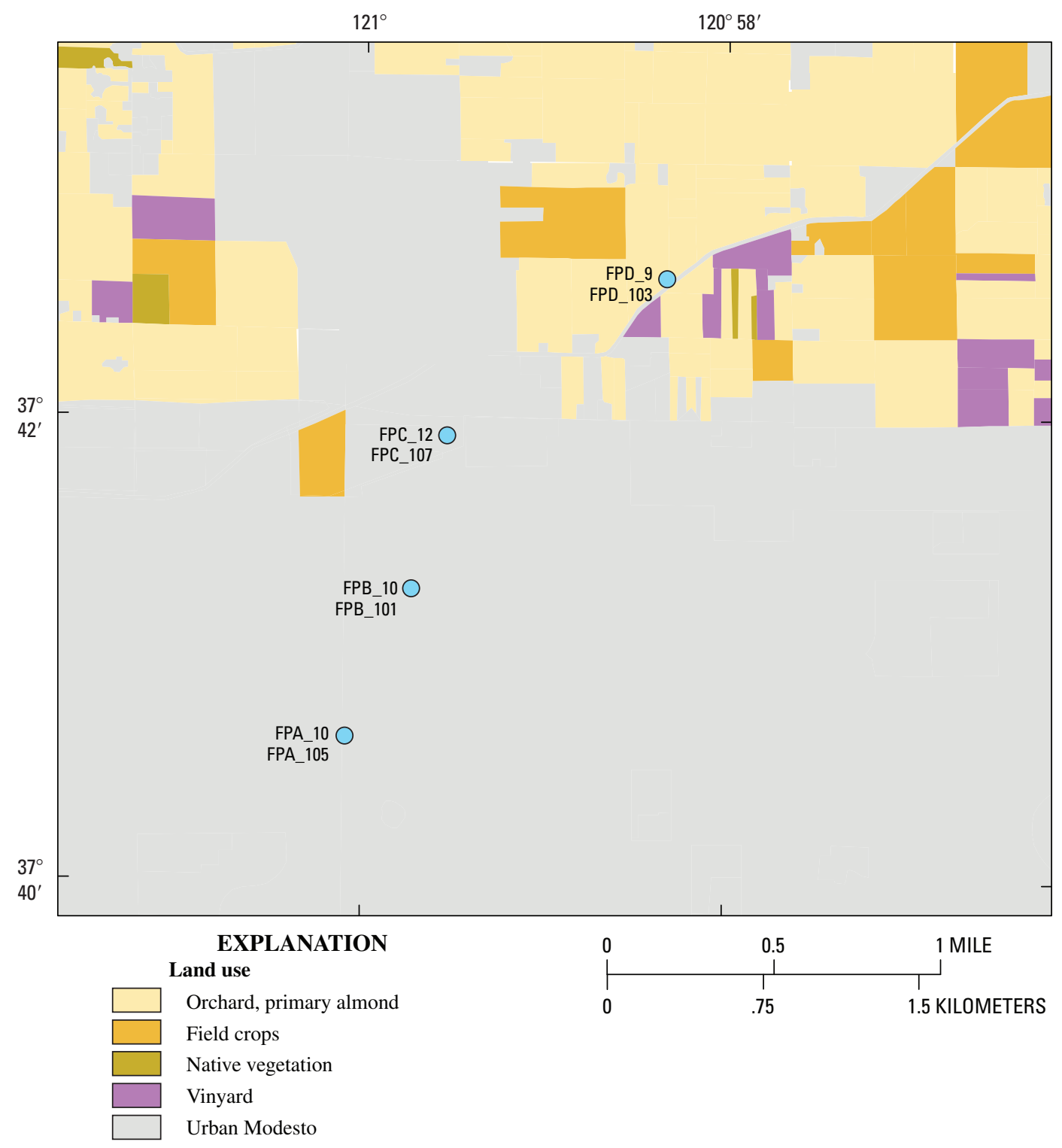

FPB_10 $\bigcirc$ USGS well cluster and depth to midpoint of screen, in meters, for shallowest and deepest wells in each cluster

Figure 2. Land use and description of U.S. Geological Survey (USGS) wells in Modesto, San Joaquin regional study area, California. 
zone (fig. 3) of the Merced River. Four to six wells at each site were used for this study; mid-screen depths ranged from about $6 \mathrm{~m}$ near the water table to about $27 \mathrm{~m}$ for those screened above the Corcoran Clay. Screen lengths for this group of wells were $0.6 \mathrm{~m}$ except at the water table $(1.5 \mathrm{~m})$. One well at the lower end of the transect was screened below the Corcoran Clay at a depth of $53 \mathrm{~m}$; the screen length was $3 \mathrm{~m}$. Fourteen of these transect wells were instrumented using pressure transducers that recorded hourly water-level measurements for periods ranging from 1 to 1.6 years.

\section{Conceptual Understanding of Ground-Water System}

The aquifer system in the regional study area is composed of Tertiary and Quaternary alluvial deposits shed from the surrounding Sierra Nevada and Coastal mountain ranges. The basin-fill comprises coalescing alluvial fans, which tend to be coarse grained near the mountains and finer grained toward the center of the basin. The Corcoran Clay Member of the Tulare

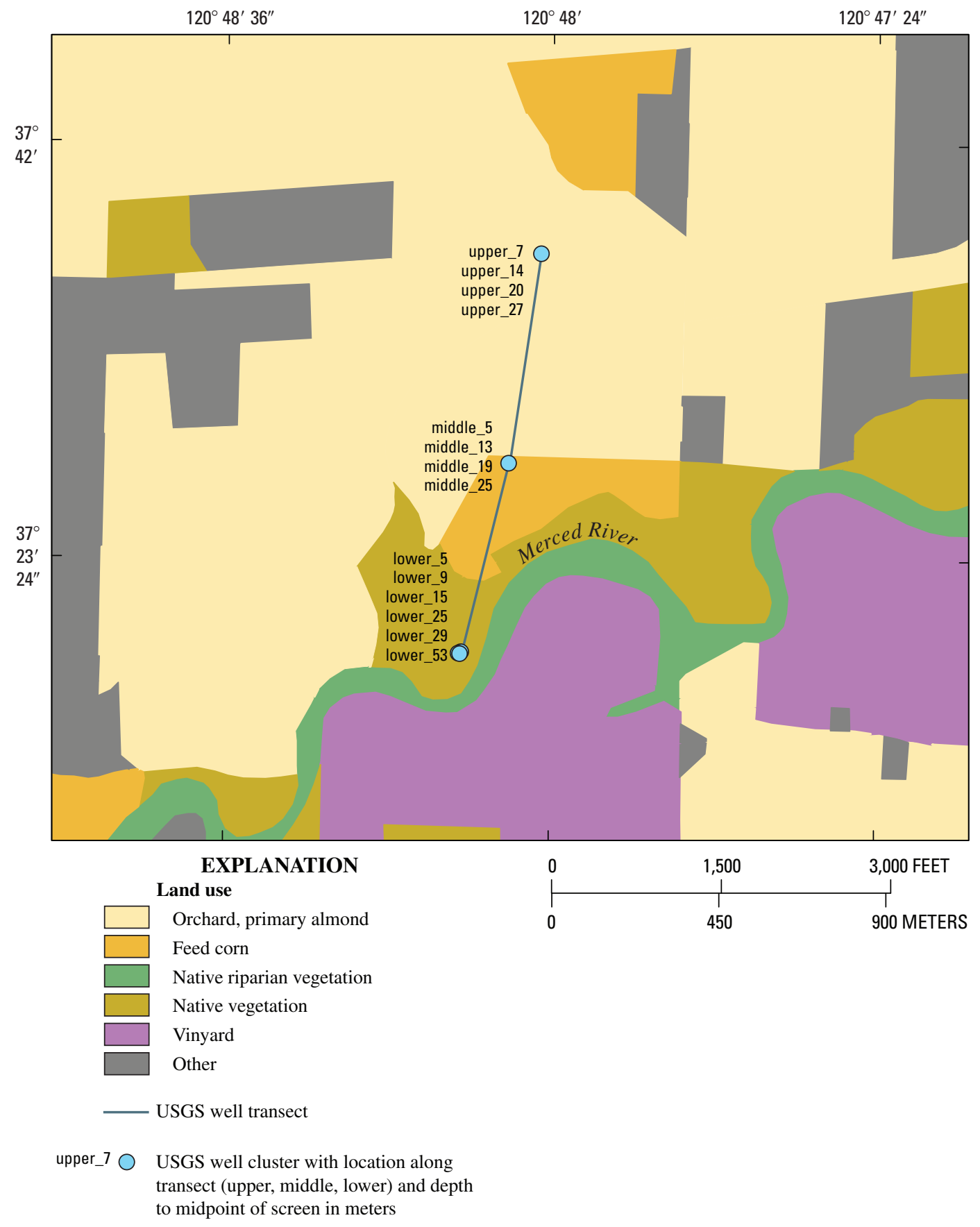

Figure 3. Land use and description of U.S. Geological Survey (USGS) transect wells, San Joaquin local study area, California. 
Formation is a lacustrine clay deposit that separates the basinfill deposits into an upper unconfined to semiconfined aquifer and a lower confined aquifer throughout much of the regional study area (Burow and others, 2004). The local study area is underlain entirely by the Corcoran Clay.

Ground-water flow directions have changed and rates have increased because of extensive development. Under natural conditions, recharge occurred in the upper alluvial fans where streams enter the basin, and ground water discharged to the San Joaquin River and surrounding marshlands. Groundwater pumping for irrigation and public supply combined with delivery of surface water for irrigation has greatly altered the distribution of recharge and discharge (Burow and others, 2004). Ground-water flow has become more complex as increased surficial recharge and ground-water withdrawal have increased vertical flow in the system; water on a lateral flow path may be repeatedly removed by pumping and reapplied at the surface.

\section{Geology}

The Central Valley is a northwest-trending structural trough between the Sierra Nevada and the Coast Ranges (Bartow, 1991). The Sierra Nevada Range lies on the eastern side of the valley, comprises primarily pre-Tertiary granitic rocks, and is separated from the Central Valley by a foothill belt of marine and metavolcanic rocks. The Coast Ranges lie on the western side of the valley and are a complex assemblage of rocks, including marine and continental sediments of Cretaceous to Quaternary age (Gronberg and others, 1998).

The San Joaquin Valley can be divided generally into three physiographic regions (fig. 1): the western alluvial fans, the eastern alluvial fans, and basin deposits (Burow and others, 1998). Alluvial fan deposits on both sides of the valley are composed predominantly of coarse-grained sediments near the head of each fan that become finer grained toward the valley trough. The sediments in the eastern alluvial fan region generally are more permeable than sediments in the western alluvial fan region because sediment-source rocks and watershed characteristics are different between the two areas. The basin deposits within the regional study area are a combination of coarse-grained channel deposits and fine-grained deposits from flood events.

Consolidated rocks and deposits exposed along the margin of the valley floor include Tertiary and Quaternary continental deposits (fig. 4), Cretaceous and Tertiary marine sedimentary rocks, and the pre-Tertiary Sierra Nevada basement complex (Piper and others, 1939; Davis and others, 1959). The Mehrten Formation, the youngest of the Tertiary rocks, is composed of volcanic-derived mafic rocks. Unconsolidated deposits in the study areas generally comprise gravel, sand, silt, and clay primarily derived from granitic sources, and most are contained within the Pliocene-Pleistocene Laguna (not mapped at the surface in study areas), Turlock Lake, Riverbank, and Modesto Formations, including the Corcoran Clay. These are interspersed with minor amounts of Holocene dune, stream-channel, and flood-basin deposits (Arkley, 1962; 1964; Davis and Hall, 1959). The Turlock Lake, Riverbank, and Modesto Formations form a sequence of overlapping terrace and alluvial fan systems (Marchand and Allwardt, 1981) indicating cycles of alluviation, soil formation, and channel incision that were influenced by climatic fluctuations and resultant glacial stages in the Sierra Nevada (Bartow, 1991).

The Corcoran Clay, a lacustrine deposit that is a key subsurface feature in the San Joaquin Valley, is a Member of the Tulare Formation (Croft, 1972). The Corcoran Clay has been correlated with the E-clay (Page, 1986), the diatomaceous clay (Davis and others, 1959), and the lacustrine clay within the Turlock Lake Formation in the regional study area (Marchand and Allwardt, 1981). Page (1986) used results of previous work and a limited number of well logs and geophysical logs to map the areal extent of this regional confining unit. Additional lithologic data were used recently to modify the mapped extent of this prominent unit in the regional study area (Burow and others, 2004). The eastern extent of the Corcoran Clay roughly parallels the San Joaquin River valley axis (fig. 4). In the regional study area, the top of the Corcoran Clay occurs between 26 and $80 \mathrm{~m}$ below land surface and the unit has a maximum thickness of $57 \mathrm{~m}$. In the local study area, the Corcoran Clay is encountered $40 \mathrm{~m}$ below land surface and is about $18 \mathrm{~m}$ thick.

The Mehrten Formation is a key subsurface feature tapped by wells in the eastern part of the study area (fig. 4). The Mehrten Formation marks a change in lithology and texture from overlying sediments of primarily unconsolidated coarse-grained sediments of arkosic composition to primarily consolidated sediments of volcanic-derived mafic materials (Burow and others, 2004). The Mehrten Formation outcrops in the eastern part of the regional study area and lies at least $120 \mathrm{~m}$ below land surface beneath Modesto.

\section{Geohydrology}

\section{Aquifer Hydraulic Properties}

Only limited information on the distribution and magnitude of aquifer hydraulic properties was available prior to this study. One available ground-water flow model was developed at a similar scale of investigation (Londquist, 1981), and it was highly generalized spatially. 


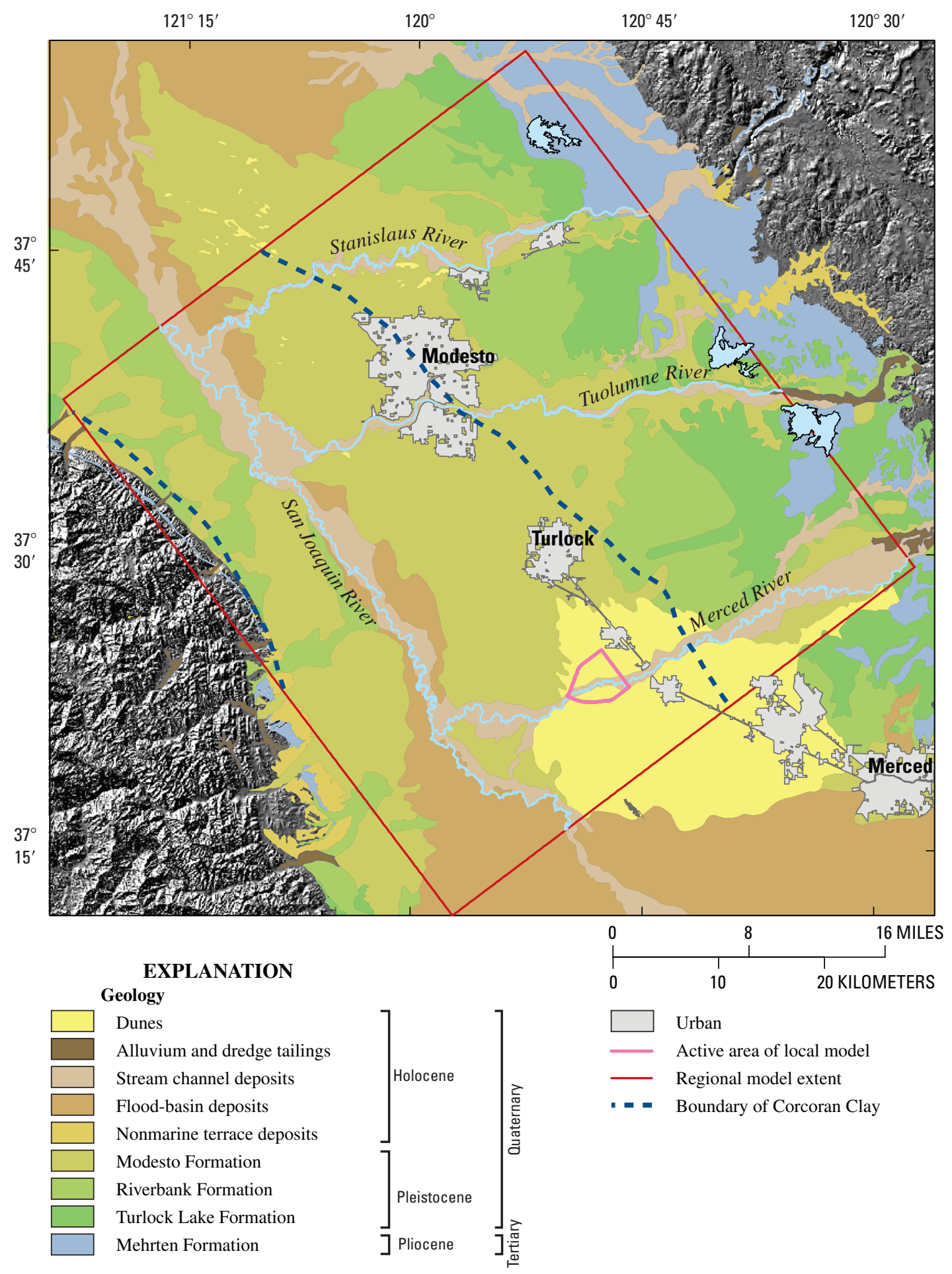

Figure 4. Selected geologic units, San Joaquin regional study area, California. 
Single-well hydraulic tests—-slug tests-were done in 18 shallow wells in the bed and on the banks of the Merced River down-gradient from the local well transect as part of this study (Zamora, 2006). The sediments tested ranged from silty sand to well-sorted coarse sand, and computed hydraulic conductivity values ranged from 15 to $250 \mathrm{~m} / \mathrm{d}$ and had a mean of $85 \mathrm{~m} / \mathrm{d}$. Slug tests done for a previous study in three wells above the Corcoran Clay along the eastern bank of the San Joaquin River within the regional study area were used to compute hydraulic conductivities of 2, 24, and $53 \mathrm{~m} / \mathrm{d}$ (Phillips and others, 1992). The sediment types that these tests represent are unknown.

Permeameter tests of cores from the Corcoran Clay indicate vertical hydraulic conductivities ranging from $1 \times 10^{-6}$ to $3 \times 10^{-6} \mathrm{~m} / \mathrm{d}$ (Page, 1977). Previous investigations, however, indicate numerous wells screened across the Corcoran Clay have locally short-circuited the impedance to flow across the clay layer and significantly enhanced intraborehole flow through the clay (Williamson and others, 1989; Belitz and Phillips, 1995). The vertical hydraulic conductivity estimated by Belitz and Phillips (1995) for an area southwest of the regional model, where the Corcoran Clay is about $100-240 \mathrm{~m}$ below land surface, is $1.6 \times 10^{-4} \mathrm{~m} / \mathrm{d}$.

\section{Lithologic Distributions}

Because available data on the hydraulic properties of the aquifer system are scarce, material properties in this study were estimated on the basis of the distribution of sediment texture or hydrofacies derived from drillers' logs, geologic logs, and geophysical logs. The regional texture distribution was estimated using the general approach of Laudon and Belitz (1991), which is easily applied to regional-scale problems. The local texture distribution was estimated using a geostatistical approach that incorporates factors related to the depositional environments (Carle, 1996). Although this method is more powerful than that of Laudon and Belitz (1991), it is difficult to apply to many regional-scale problems, owing to regional variability in depositional environments.

\section{Regional Study Area}

To facilitate this texture-based approach for the regional model, a database was constructed as part of a cooperative effort between the USGS and the Modesto Irrigation District to organize information on well construction and subsurface lithology in the study area (Burow and others, 2004). About 10,000 drillers' logs were examined. Because sediment descriptions on drillers' logs can be ambiguous and widely variable, a rating scheme was developed to select a subset of about 3,500 logs for further use. The database contains lithologic and well-construction information, which was used to vertically distribute ground-water pumping in the flow model.
A geostatistical approach was used to generate a heterogeneous hydraulic-conductivity field for the regional flow model using the primary texture of sediments from the database (Burow and others, 2004). Lithologic descriptions in the database were expressed as a percentage of coarse-grained sediment for 1-m depth intervals. These percentages were then interpolated using three-dimensional kriging, with no lateral anisotropy, over a grid equivalent to that of the regional model in the horizontal dimension for successive 10-m thick intervals in the vertical dimension. These values were then interpolated over the variable-thickness model grid to obtain an estimated distribution of sediment texture throughout the regional model domain. A more detailed description of kriging parameters is provided by Burow and others (2004). Estimated texture distributions for depth slices below the land surface are shown in figure 5. The estimated texture distributions were well constrained by sediment texture data to a depth of about $50 \mathrm{~m}$, reasonably constrained to $100 \mathrm{~m}$, and poorly constrained below $100 \mathrm{~m}$. For the deeper parts of the aquifer system, for which no data were available, the texture value in the lowest layer estimated was duplicated in all underlying model cells. These cell-by-cell texture values were used to generate the distribution of hydraulic conductivity values as described in the section "Estimation of Aquifer Hydraulic Properties," under "Ground-Water Flow Simulations."

\section{Local Study Area}

The spatial distribution of sedimentary hydrofacies in the local model area was simulated using Transition-Probability Geostatistical Software (TProGS) (Carle, 1996; Carle, 1997; Carle and Fogg, 1996; Carle and Fogg, 1997; Carle and others, 1998). Using TProGS, probabilities of encountering one defined hydrofacies next to another are determined from borehole and (or) other raw data. Markov-chain models approximating these transition probabilities are used in sequential indicator simulation, and these results are smoothed with simulated annealing to generate three-dimensional realizations that honor the measured data points and transition probabilities. This method preserves cross-correlations between sediment types that can affect preferential flow through interconnected high-conductivity zones (Fogg and others, 2001).

A single realization generated using TProGS represents one of many possible distributions of the defined hydrofacies. A key advantage of this method is that the same input can be used to generate hundreds of realizations, which provides the opportunity to explore a wide range of equally probable hydrofacies distributions. 


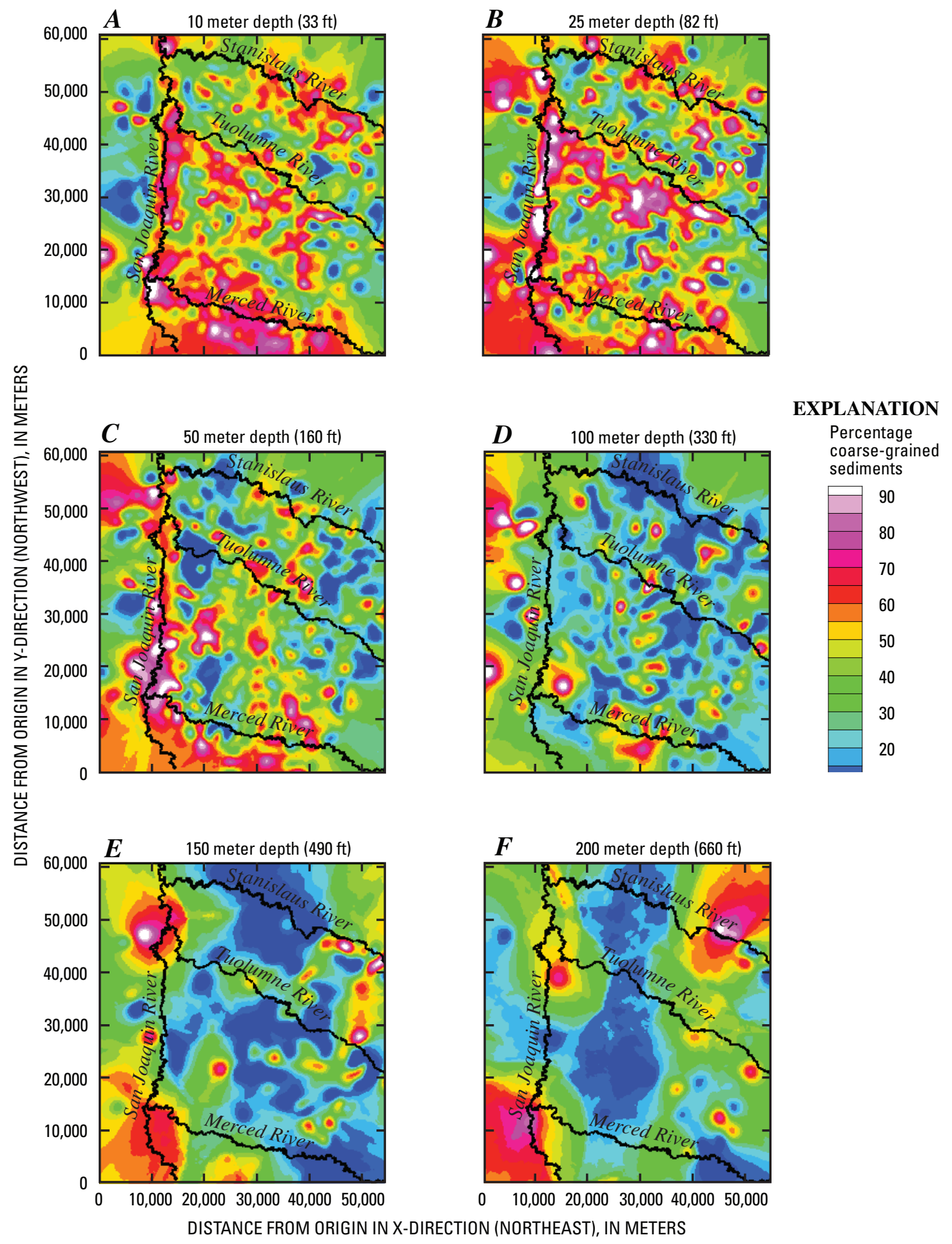

Figure 5. Two-dimensional slices through three-dimensional model of percentage coarse-grained sediments, San Joaquin regional study area, California. Modified from Burow and others (2004). 
Geostatistical realizations of the local study area were bounded by or included three major geologic features of the unconfined to semiconfined aquifer: the Corcoran Clay, Pleistocene alluvial fan deposits, and incised Holocene river deposits (Marchand and Allwardt, 1981). The Corcoran Clay is a semi-permeable barrier to vertical flow between the unconfined to semiconfined aquifer and the confined aquifer, and was the lower boundary for the geostatistical realizations. Overlying the Corcoran Clay, Pleistocene alluvial fan deposits account for most of the permeable sediments. Adjacent to the Merced River, Holocene alluvium fills an incised river valley in the Pleistocene alluvial fan deposits. The lower boundary of Holocene alluvium along the Merced River was estimated using cores from the USGS well transect, and previous maps and reports on the surficial geology of the area (Marchand and Allwardt, 1978, 1981). These boundaries were used to specify the spatial extent of sedimentary sequences in geostatistical realizations.

Pleistocene alluvial fan deposits were characterized using geologic logs that describe the USGS transect wells. The logs had a maximum resolution of about $0.3 \mathrm{~m}$ for those boreholes drilled using an air hammer and about $1.5 \mathrm{~m}$ for those drilled using mud rotary. Clay, silt, silty sand, and sand were chosen as the representative hydrofacies on the basis of the frequency of observation of various sediment types in cores collected during drilling, Each lithologic description in the logs was assigned to one of these hydrofacies, and vertical transition probabilities (fig. 6), mean thicknesses, and volumetric proportions (table 1) were computed from this data set. Horizontal transition probabilities were estimated by multiplying the vertical mean lengths by factors of about 200 in the dip (X, toward the southwest) direction and about 100 in the strike (Y) direction (table 1). The scaling factors, which are greater along the depositional slope, were chosen on the basis of observations of horizontal continuity of sedimentary layers between wells and previous reports of the area's sedimentary geology (Marchand and Allwardt, 1981).

Changes in stratigraphic orientation owing to the gradual downwarping of sediments after deposition, or areal variability in rates of deposition, were approximated by setting the dip parallel to the gently undulating surface of the Corcoran Clay at that interface, and to zero at the ground surface. In the interior of the alluvial fan sediments, dip values were assigned for each location (X, Y, and Z) by linear interpolation between the dip at the ground surface and at the surface of the Corcoran Clay. The dip direction was set parallel to the $\mathrm{X}$ axis.

For Holocene alluvium, sediments were assigned to hydrofacies containing silt, silty sand, or sand. Proportions and mean thicknesses were calculated from the upper part of a geologic log of a borehole at the lower end of the well transect (table 1). Available data were insufficient to characterize cross-correlations among sediment types; therefore, transition probabilities were derived using mean lengths and maximumentropy Markov chain models (Carle and Fogg, 1997). Mean lengths (table 1) were estimated from the dimensions of the Merced River channel and local floodplain areas as mapped by Marchand and Allwardt (1978). The azimuth of the dip of the Holocene alluvium was set parallel to the centerline of the mapped alluvium and the dip was set to zero.

Two hundred realizations of the three-dimensional distribution of hydrofacies were generated for the local study area. For these realizations, drillers' logs and USGS geologic logs were used as conditioning data. Conditioning refers to the inclusion of information that will affect the realization; the degree to which the realization is affected depends on the user-specified accuracy of the information. In this case, drillers' logs contain a variety of terminology used to describe sediments and typically are not very detailed; therefore, most observations were treated as "soft" conditioning data by assigning a probability, $p$, where $0 \leq p \leq 1$ for each of the simulated hydrofacies on the basis of the specific well log description (table 2). USGS geologic logs were used as "hard" conditioning data, where $p=1$. Separate realizations were generated for the Holocene alluvium and Pleistocene alluvial fans. The simulated stratigraphic sequences were then merged into composite realizations that incorporated sequence boundaries, conditioning data, and simulated hydrofacies for the Holocene alluvium and Pleistocene alluvial fans above the surface of the Corcoran Clay.

Hydrofacies distributions for the local model improved the regional model in that area. Boreholes used to estimate regional sediment texture were sparse in the local model area, and did not include the three drilling sites along the USGS well transect. Regional kriging results, which depicted the local study area as being very coarse-grained throughout, compared poorly to data from sites along the transect, and the regional model did not closely simulate measured local conditions. Therefore, regional sediment texture estimates were replaced with TProGS-generated hydrofacies distributions in the local model area. The hydrofacies were translated crudely to percent coarse-grained materials as follows: sand and silty sand were considered 100 percent coarse-grained, and silt and clay zero percent. These percentages were averaged for all local cells within each regional cell.

\section{Ground-Water Occurrence and Movement}

Ground water occurs in the unconfined to semi-confined aquifer above and east of the Corcoran Clay, within the Corcoran Clay, and in the confined aquifer beneath the Corcoran Clay. The thickness of the unconfined to semiconfined aquifer above the Corcoran Clay ranges from about 26 to $80 \mathrm{~m}$ in the regional study area. East of the Corcoran Clay, this aquifer comprises primarily unconsolidated alluvial sediments, but includes the upper part of the more-consolidated Mehrten Formation. Irrigation and public-supply wells were completed in coarse-grained units in the upper Mehrten. The confined aquifer comprises alluvial sediments and upper Mehrten Formation sediments from beneath the Corcoran Clay to the deepest occurrence of fresh water. The contribution of ground water from the consolidated rocks beneath the primary aquifers was assumed negligible and was not considered. 

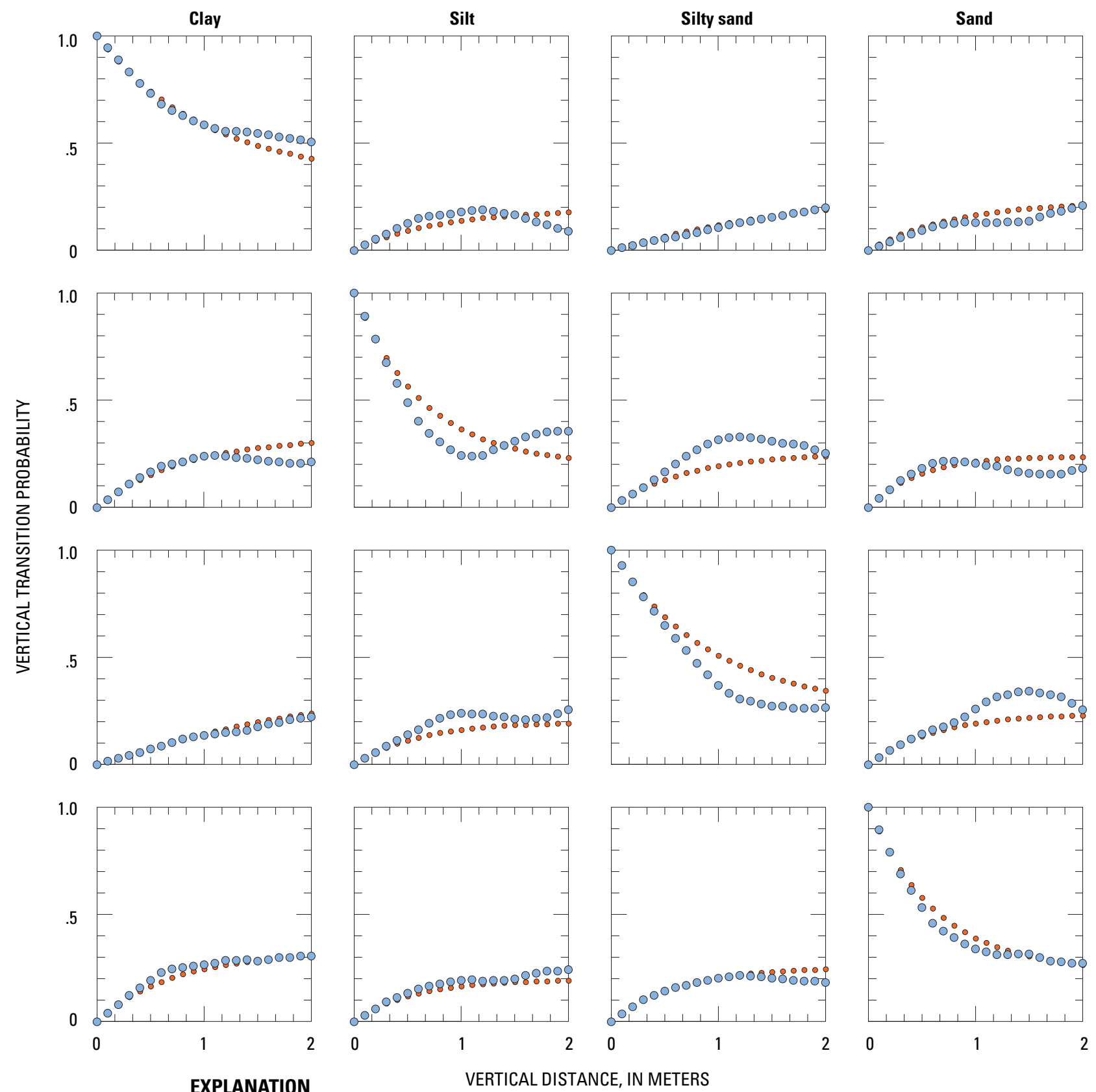

Transition probability

VERTICAL DISTANCE, IN METERS

- Measured from USGS borehole data

- Markov chain approximation

Figure 6. Vertical transition probabilities used to constrain vertical sequences of hydrofacies, San Joaquin local study area, California.

USGS, U.S. Geological Survey. 
Table 1. Proportions and mean lengths of hydrofacies used in local model, San Joaquin local study area, California.

[Due to rounding, sum of proportions do not equal 1.0]

\begin{tabular}{llcrrr}
\hline \multirow{2}{*}{ Geologic age } & \multicolumn{2}{c}{ Hydrofacies } & \multirow{2}{*}{ Proportion } & \multicolumn{3}{c}{ Mean length, in meters } \\
\cline { 4 - 6 } & & & $\mathbf{X}$ & $\mathbf{Y}$ & $\mathbf{Z}$ \\
\hline Holocene & Silt & 0.24 & 80 & 100 & 1.26 \\
& Silty sand & 0.46 & 60 & 100 & 1.18 \\
\multirow{3}{*}{ Pleistocene } & Sand & 0.31 & 40 & 160 & 0.93 \\
& Clay & 0.37 & 395 & 184 & 1.78 \\
& Silt & 0.20 & 185 & 116 & 0.92 \\
& Silty sand & 0.23 & 274 & 137 & 1.37 \\
& Sand & 0.21 & 191 & 72 & 0.96 \\
\hline
\end{tabular}

Table 2. Soft-conditioning probabilities assigned to hydrofacies for non-U.S. Geological Survey well log descriptions, San Joaquin local study area, California.

[non-USGS, non-U.S. Geological Survey]

\begin{tabular}{lllcc}
\hline Description in non- & \multicolumn{4}{c}{ Probability of hydrofacies occurrence } \\
\cline { 2 - 5 } \multicolumn{1}{c}{ USGS well log } & Clay & Silt & Silty sand & Sand \\
\hline Clay & 0.75 & 0.25 & 0 & 0 \\
Clayey sand & 0 & 0 & 1 & 0 \\
Clayey shale & 0.5 & 0.5 & 0 & 0 \\
Gravelly sand & 0 & 0 & 0 & 1 \\
Hard pan & 0.5 & 0.5 & 0 & 0 \\
Rock & 0.5 & 0.5 & 0 & 0 \\
Sand & 0 & 0 & 0.25 & 0.75 \\
Sandy clay & 0.5 & 0.5 & 0 & 0 \\
Sandy clayey shale & 0.5 & 0.5 & 0 & 0 \\
Sandy gravel & 0 & 0 & 0 & 1 \\
Sandy shale & 0.5 & 0.5 & 0 & 0 \\
Sandy silt & 0 & 1 & 0 & 0 \\
Sandy topsoil & 0 & 0.4 & 0.4 & 0.2 \\
Shale & 0.5 & 0.5 & 0 & 0 \\
Silty clay & 0.6 & 0.4 & 0 & 0 \\
Silty sand & 0 & 0 & 1 & 0 \\
Topsoil & 0.3 & 0.3 & 0.3 & 0.1 \\
Unknown & 0.25 & 0.25 & 0.25 & 0.25 \\
\hline
\end{tabular}

Under natural conditions, ground water was primarily recharged at the upper parts of the alluvial fans where the major streams enter the valley (fig. 7). Ground-water flow followed the southwest slope of the basement complex and the dip of the overlying sedimentary deposits toward the southwest in the direction of the valley trough. Artesian conditions near the San Joaquin River indicated discharge to the river and surrounding marshlands (Davis and others, 1959).

Ground-water development in the basin changed groundwater flow patterns. Historically, water pumped for agricultural irrigation and irrigation return flows is much greater than natural discharge and recharge, which has caused an increase in vertical flow in the system (fig. 7B) (Page and Balding, 1973; Londquist, 1981). Ground water generally flows toward the southwest, as occurred prior to development (fig. 8). However, ground water moving along a lateral flow path may be extracted by wells and reapplied at the surface multiple times before reaching the valley trough (fig. $7 B$ ), at which point it may flow beneath the river toward pumping centers on the west side of the valley rather than discharge to the river. South of the Tuolumne River is a centrally located ground-water flow divide (fig. 8), east of which water flows eastward toward irrigation wells in an agricultural area with no surface-water supplies. West of the flow divide, water generally flows westward toward the valley trough.

The western part of the study area along the San Joaquin River is an area of ground-water discharge where the water table is shallow, often within $3 \mathrm{~m}$ of the land surface. Water is pumped from this area to lower the water table so crop roots are not damaged; this water is added to irrigation canals. Depth to the water table increases eastward, particularly south of the Tuolumne River, where depths can exceed $40 \mathrm{~m}$ within the large cone of depression (fig. 8). 
$\boldsymbol{A}$
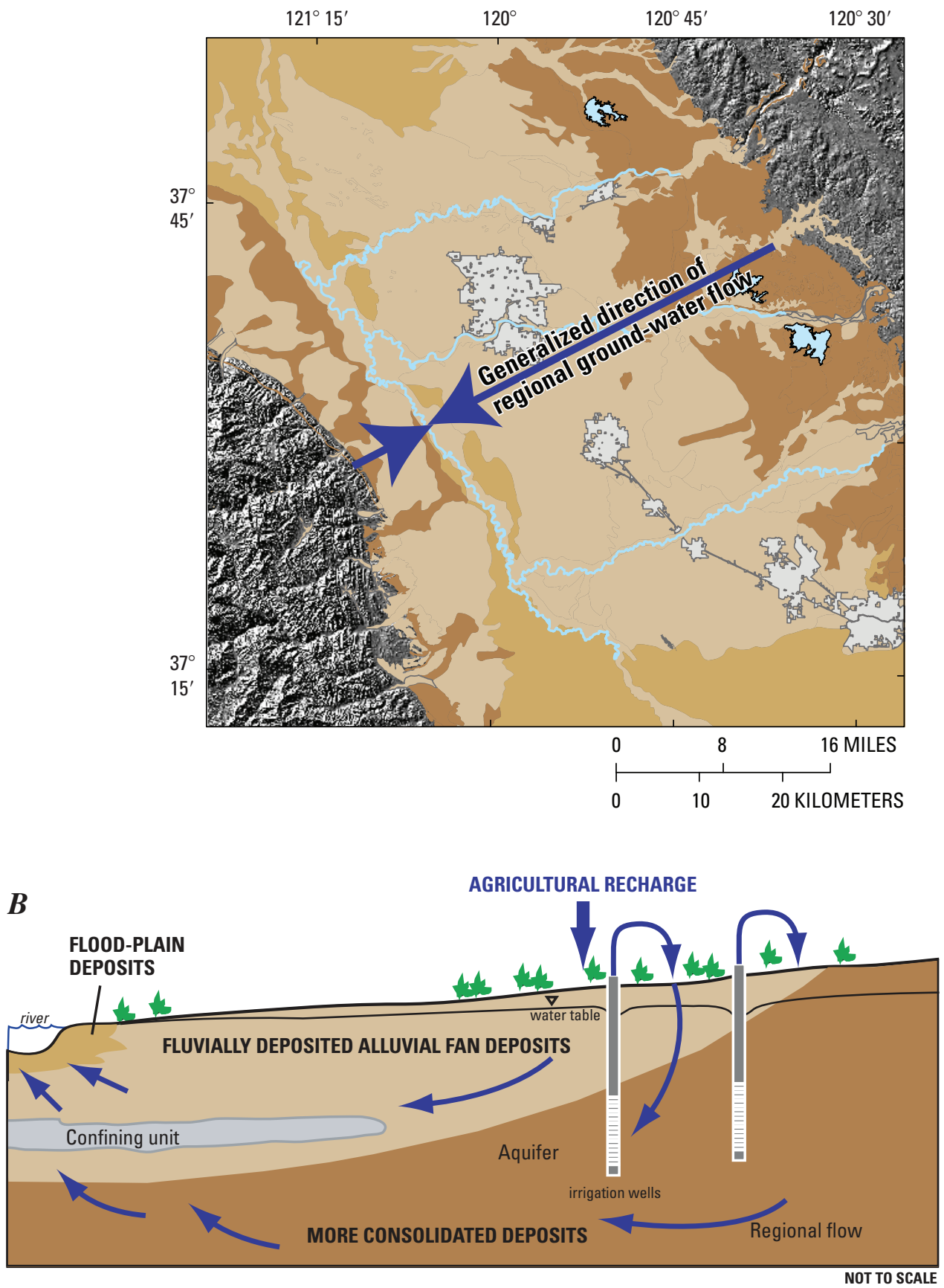

Figure 7. Conceptual diagram of $(A)$ regional lateral ground-water flow and $(B)$ vertical flow influenced by agricultural practices and natural discharge zones. Modified from Burow and others (2004). 


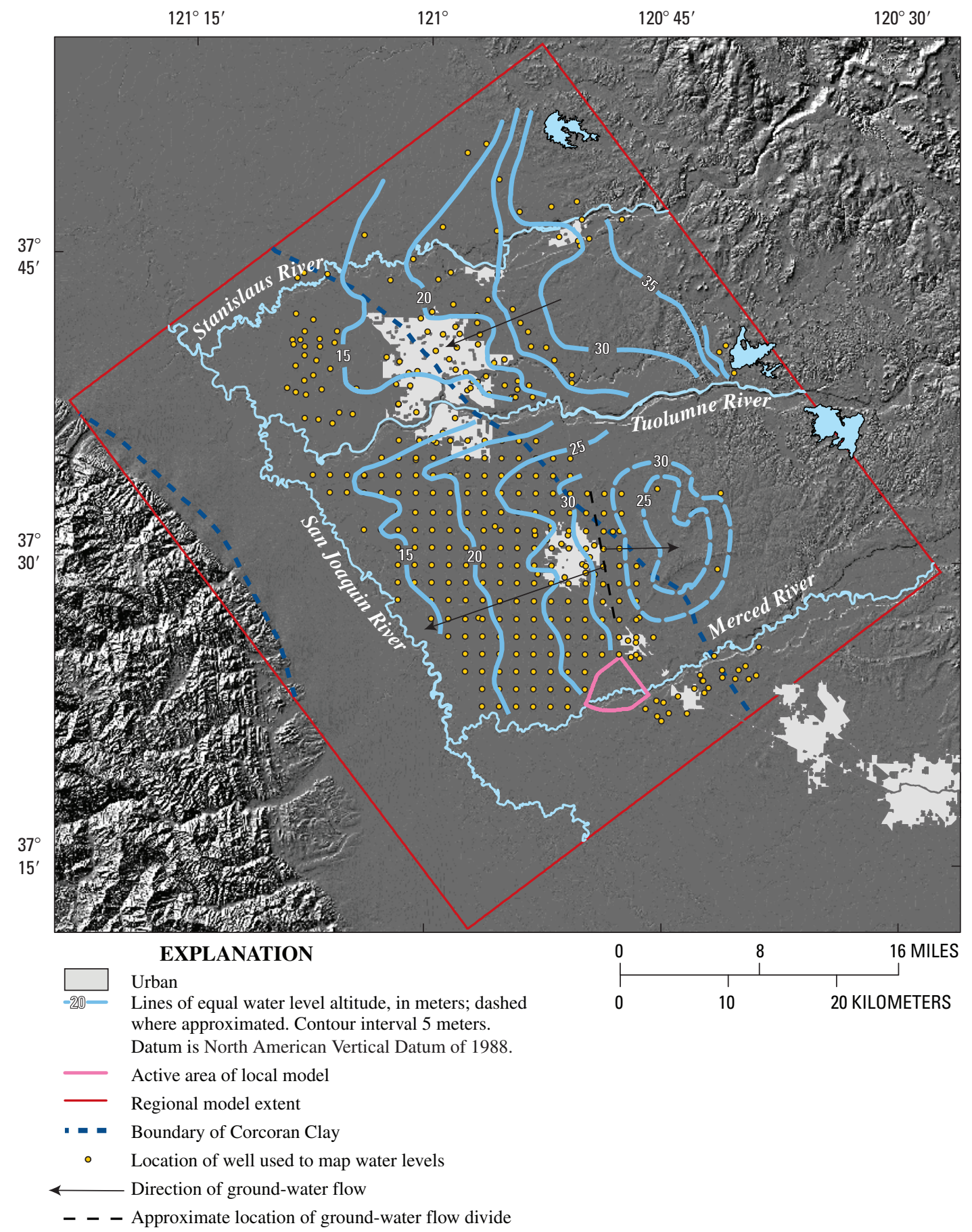

Figure 8. Contours of measured water-level altitudes in the unconfined to semiconfined aquifer, spring 2000, San Joaquin regional study area, California.

Water levels near the city of Modesto generally decreased until the early 1990s (fig. 9). This decrease likely was caused by increased urban development and associated pumping for public supplies punctuated by drought conditions in 1976 and 1987-92. A series of wet years in the mid-1990s and completion of a surface-water treatment plant in 1994, which provided additional surface-water supplies for public and industrial uses, resulted in a recovery of water levels (fig. 9).
Data from USGS wells in the Modesto urban area show that vertical hydraulic gradients from the water table (about $10 \mathrm{~m}$ below land surface) to the deeper production zones of most municipal wells (about 40-100 m below land surface) are strongly downward and larger during spring and summer (about 0.2-0.3) than during fall and winter (fig. 10). Seasonal water-level fluctuations are about $6 \mathrm{~m}$ in the deeper wells and generally less than $1 \mathrm{~m}$ at the water table in the Modesto urban area. 


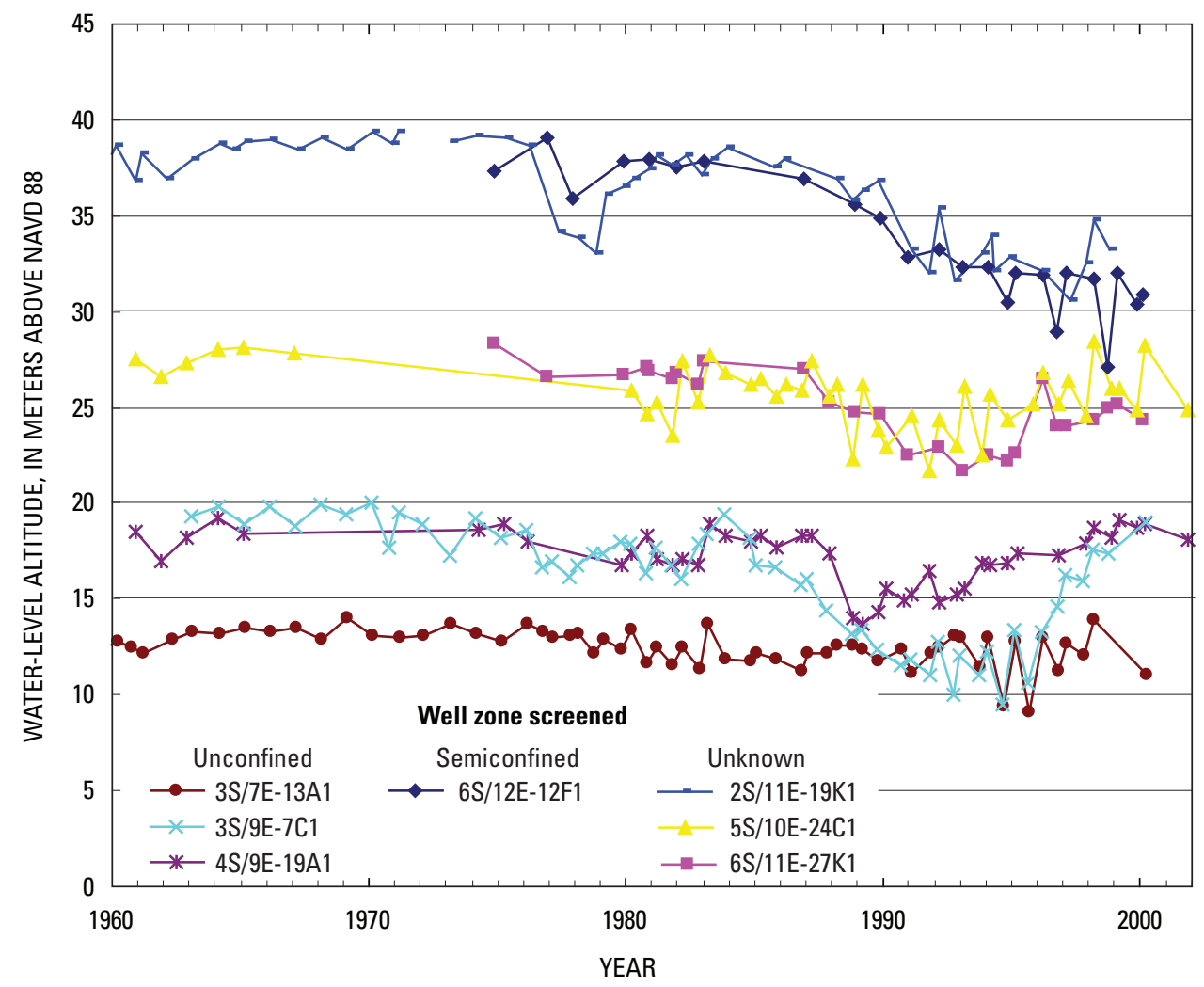

Figure 9. Hydrographs of measured water-level altitudes for selected irrigation wells from 1960 to 2001, San Joaquin regional study area, California.

Well locations shown on figure 1 .

Water levels measured in the transect wells in the local study area are shown in figure 11 (locations of wells shown in figure 3). These data show a weak downward gradient during the spring and summer below the almond orchard at the upper end of the well transect, and essentially no vertical gradient in this area the rest of the year. Measurements at the middle site show no vertical gradient year-round in the three deepest wells. The shallowest well at this site was screened in sandy silt and was not properly developed, but the hydrograph shows irrigation cycles in the adjacent corn field. Vertical gradients underlying natural vegetation near the Merced River at the lower end of the well transect were weakly upward, with the exception of several reversals when water levels were at their highest. Temporal variability of measured water levels was dominated by irrigation at the upper end of the well transect, the river stage at the lower end, and a combination of these influences in the middle. The hydrograph for the well below the Corcoran Clay at the lower end of the well transect (not shown in fig. 11) indicates a strong downward gradient across the unit during the irrigation season (average of about 0.3 ) and little or no vertical gradient the rest of the year.

\section{Water Budget}

Sources of recharge in the regional study area include agricultural return flow, infiltration of precipitation, reservoir leakage, and inflow from rivers. Ground-water discharges to pumping wells, rivers, transpiration, and evaporation. Information is available for some of these processes in the regional study area. Results from a recent 3-month study conducted by the Modesto Irrigation District, which manages the Modesto Reservoir, suggest a leakage rate of about 67,600 to $84,500 \mathrm{~m}^{3} / \mathrm{d}$ (Walter Ward, Modesto Irrigation District, oral commun., 2002). The interaction of ground water and surface water is largely unknown, but some data are available. A previous study of a 19-mile reach of the San Joaquin River within the regional study area showed predominantly gaining conditions during an 11-month period of drought conditions during 1988-89 (Phillips and others, 1991). Temperature and waterlevel measurements made within and below the Merced River as part of this study indicated predominantly gaining conditions within the local study area (Zamora, 2006). Additionally, a water-level map that includes the regional study area (fig. 8) suggests losing conditions in the upper reaches of the Stanislaus, Tuolumne, and Merced Rivers, and gaining conditions in the lower reaches. 


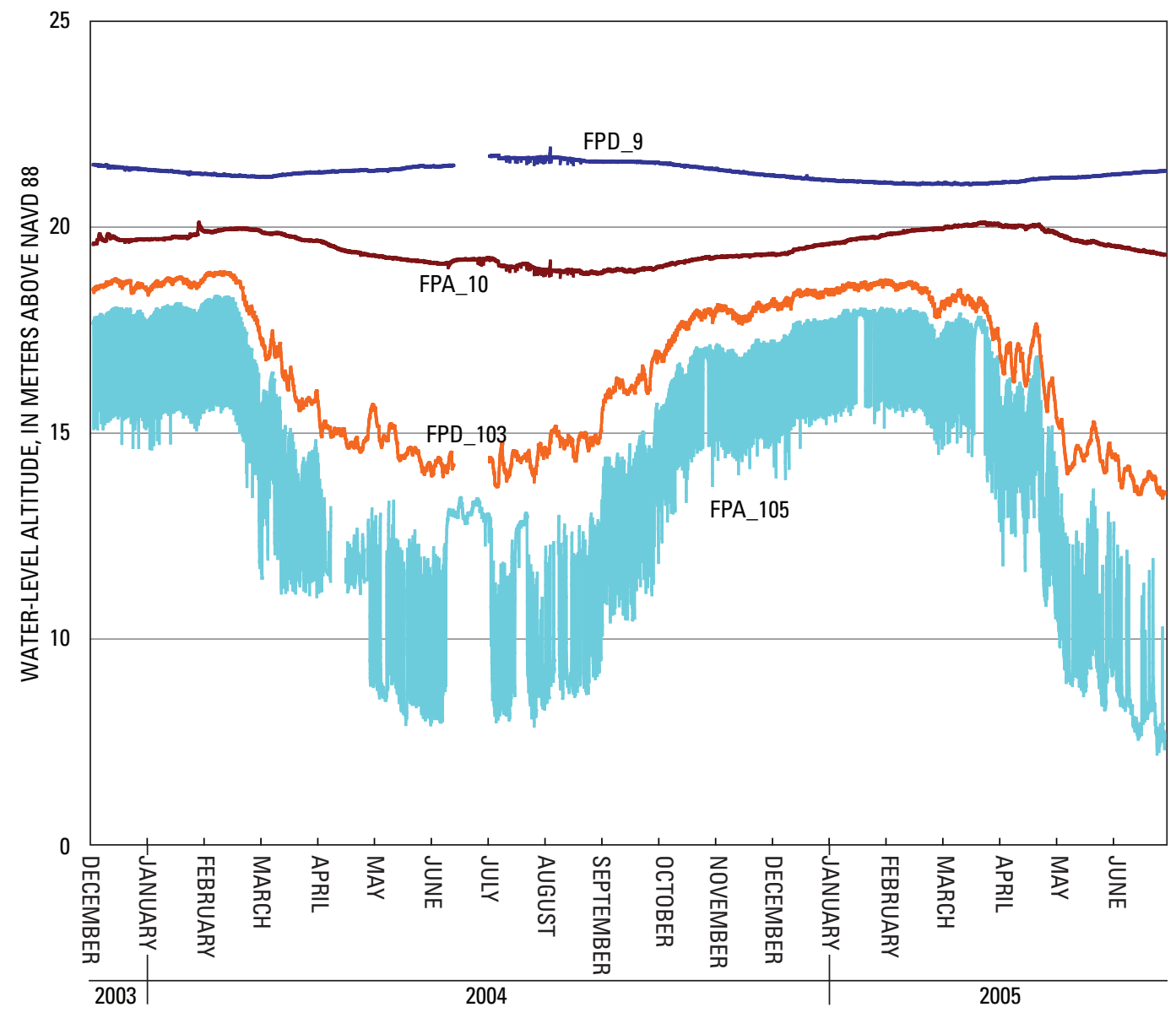

Figure 10. Hydrographs of water-level altitudes measured hourly in U.S. Geological Survey monitoring wells in urban Modesto from December 2003 to July 2005, San Joaquin regional study area, California.

Locations of FPA and FPD wells shown on figure 2.

Discharge to pumping wells was measured for urban wells and wells owned or used by irrigation districts. No data were available for pumpage from domestic wells. Although domestic wells are common in the study area, much of the water from these small-capacity wells is returned to the aquifer system by way of septic systems; therefore, the net use was assumed to be a small percentage of total pumping. Data on private agricultural pumping are not available; nor are data on evaporation from the shallow water table.

Estimates of many of the key components of recharge and discharge-agricultural return flow, infiltration of precipitation, transpiration, and private agricultural ground-water pumping — have been made using a water-budget approach (Burow and others, 2004) for water-year 2000 (October 1, 1999, through September 30, 2000). This approach and minor modifications are described generally herein; for details, the reader is referred to Burow and others (2004). Surface water and ground water are used for irrigation in the agricultural areas. Surface-water delivery data were available for most of the regional study area, although private pumpage records were not. Ground-water use in agricultural areas and areal recharge estimates were well constrained by the regional water budget.
The water budget was delineated geographically by dividing the regional study area into subareas for which surfacewater deliveries could be obtained or estimated. A separate water budget was calculated for each of the resulting 47 subareas (fig. 12), which included agricultural and urban settings, foothill areas with natural vegetation, riparian areas having natural vegetation and (or) crops, and reservoirs.

Digital land-use data (California Department of Water Resources, 2001a,b) were used to estimate the water budget for subareas containing primarily non-urban land (Burow and others, 2004). The area of each crop or other vegetation type was determined using a geographic information system (GIS). A daily crop demand was calculated on the basis of crop or vegetation type and climate, and a total daily irrigation demand was estimated for each subarea. The total irrigation demand was met by a combination of surface-water deliveries, ground water pumped by irrigation districts, and private ground-water pumping. The total reported or estimated monthly surface-water and ground-water deliveries were subtracted from the estimated monthly irrigation demand to determine the monthly unmet irrigation demand. Private ground-water pumping was then assumed to equal this residual irrigation demand. 


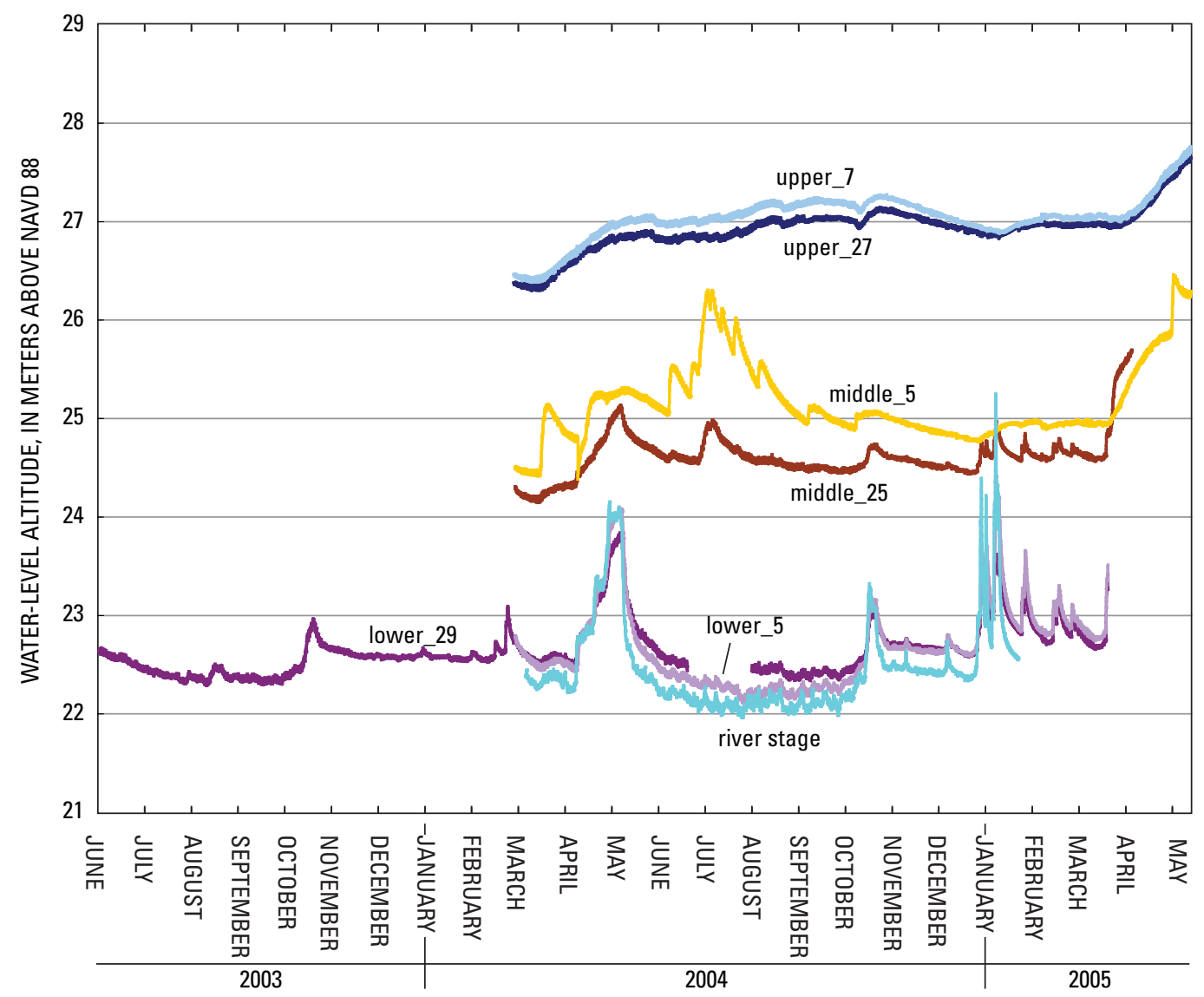

Figure 11. Hydrographs of water-level altitudes measured hourly in U.S. Geological Survey monitoring-well transect from June 2003 to May 2005, San Joaquin local study area, California. Well locations shown on figure 3.

Recharge was estimated differently for areas containing native vegetation, irrigated crops, and urban land. The recharge for each of these areas estimated by Burow and others (2004) was reduced by 10 percent during calibration of the regional model. Recharge in areas with native vegetation was based on an assumed fraction of precipitation that did not run off and was not consumed (transpired). Because consumptive use for native vegetation was unknown, it was assumed that about 40 percent of precipitation runs off or is consumed in the foothill areas. This differs from the assumption in Burow and others (2004) of no runoff or consumption of precipitation in the foothills.

Recharge in irrigated agricultural areas was estimated as the portion of precipitation and irrigation not consumed by the crops (consumptive use). The consumptive use of applied water was estimated to be 63 percent for most of the regional study area on the basis of calculated values for two subareas receiving surface-water deliveries and having few known wells (among the 3,500 wells cataloged from drillers' logs). This estimate was considered reasonable because crops are cultivated in sandy soils and irrigated by flooding and permanent sprinklers. Consumptive use of applied water was assumed to be 80 percent in the older fan deposits in the foothill areas, where sediments are more indurated and efficient irrigation methods such as micro-sprinkler and drip are used.

For the urban areas, recharge from delivered water was estimated using the minimum-month method to determine indoor and outdoor water use (California Department of Water Resources, 1994). Ten percent of the estimated outdoor use was subtracted from the total to account for leakage from water distribution lines (California Department of Water Resources, 1994). Fifty percent of the remaining outdoor water use was assumed to be consumptive use for landscape irrigation or runoff to streams, and the remainder was assumed to contribute to urban recharge (Burow and others, 2004). Recharge in the urban area from precipitation was assumed to be 50 percent of total precipitation because much of the runoff in Modesto and other urban areas is drained through largediameter boreholes backfilled with rock. These "rock wells" are direct conduits to the water table. 


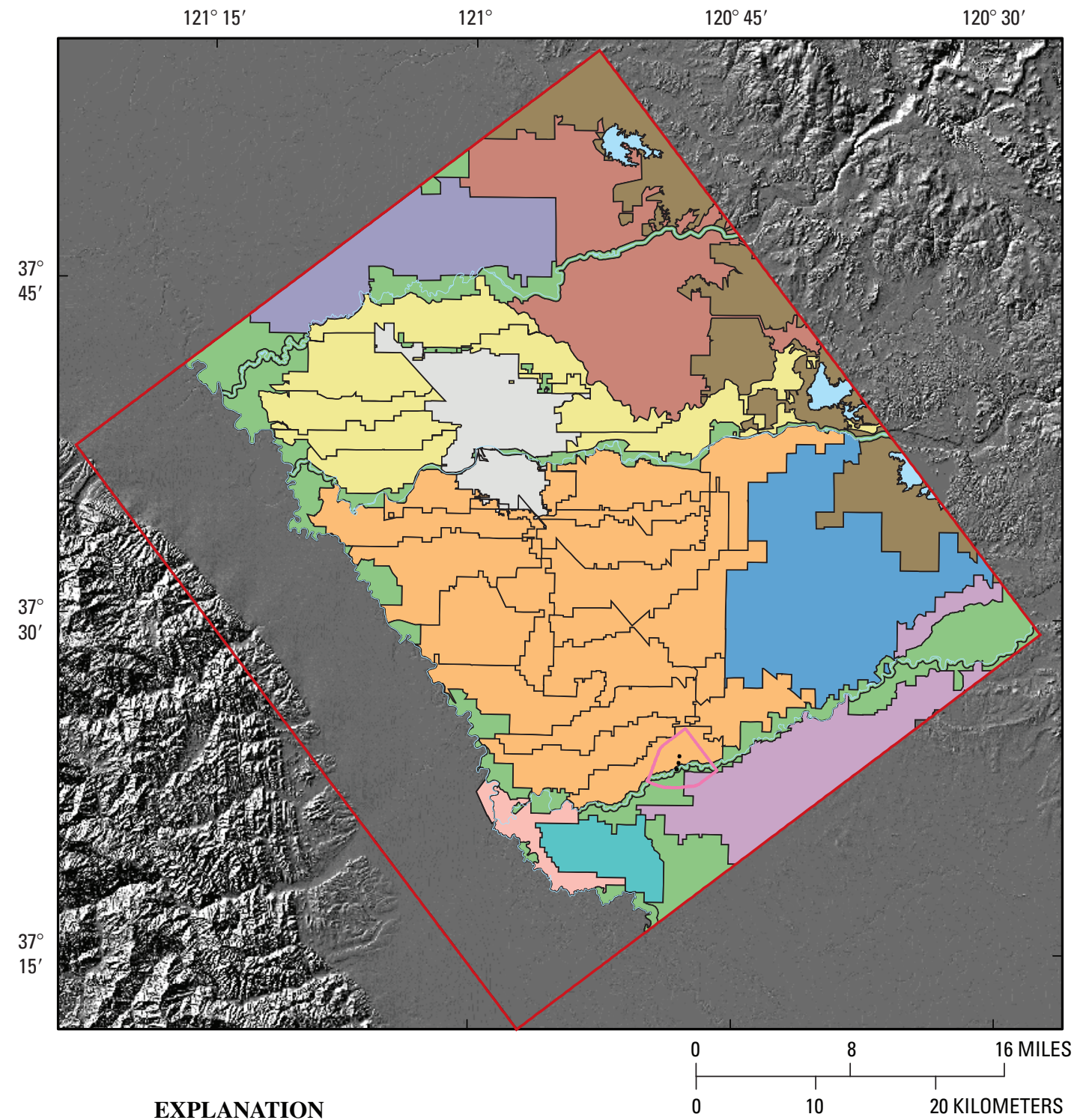

Agricultural, native, or urban area represented by one or more water-budget subareas

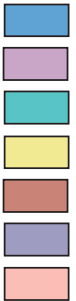

Eastside Water District

Merced Irrigation District

Merquin Community Water District

Modesto Irrigation District

Oakdale Irrigation District

South San Joaquin Irrigation District

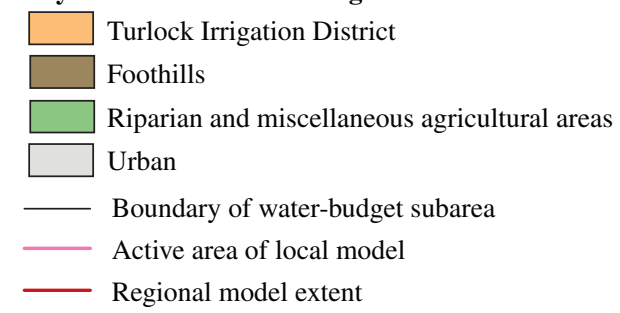

Figure 12. Subareas of regional model used for water-budget calculations, San Joaquin regional study area, California.

Modified from Burow and others (2004). 
The estimated average areal recharge rate for the regional study area was about $0.54 \mathrm{~m} / \mathrm{yr}$; the highest recharge rates were for the agricultural areas in the southwestern part of the study area (fig. 13) and along the rivers in the northeastern part. The lowest estimated recharge rates were for the foothills and the urban areas. Similarly, the highest estimated pumping rates were for the agricultural areas in the southwestern part of the regional study area (fig. 14). The relatively high rates of pumping and recharge in the southwestern agricultural areas were related, in part, to the irrigation efficiency and the supplemental pumping required to manage the shallow water table.

\section{Ground-Water Age}

Samples collected from most of the USGS wells along the transect in the local study area were analyzed for sulfur hexafluoride $\left(\mathrm{SF}_{6}\right)$, an environmental tracer that has been used to estimate ground-water age (Busenberg and Plummer, 2000). Atmospheric concentrations of $\mathrm{SF}_{6}$ were very low prior to 1965 and have increased since then, making it a good means of dating young ground water. Concentrations of $\mathrm{SF}_{6}$ in water samples from the USGS well transect (Larry Puckett, U.S. Geological Survey, written commun., 2005) are compared in this report to concentrations estimated using simulated travel times from the water table to these wells and the historical atmospheric concentration of $\mathrm{SF}_{6}$ (Böhlke, 2005).

\section{Ground-Water Flow Simulations}

Steady-state models of ground-water flow in the regional and local study areas were developed using MODFLOW2000 (Harbaugh and others, 2000) to provide tools to help understand the flow system at both scales and the associated transport and fate of agricultural chemicals at the local scale. Lateral boundaries of the local model were defined by regional model results and assigned as specified flow rates.

Both models simulate water-year 2000, when the groundwater system was in a quasi-steady-state condition. Measured water levels in the regional study area suggest much of the system has been at equilibrium for many years, particularly the areas that have a shallow water table downgradient from Modesto and Turlock, including the local study area (fig. 9). The two areas where water levels have recently changed are Modesto and the agricultural area upslope from Turlock. Water levels recovered rapidly when surface water was imported to the Modesto area in 1995, but the recovery slowed by 2000. Upslope from Turlock, water levels declined for about 2 decades because of increased ground-water use associated with new agricultural development. Although data for this area are sparse, they suggest water levels may have approached equilibrium.

\section{Spatial Discretization}

\section{Regional Model}

The regional model area is in the northeastern San Joaquin Valley extending from north of the Stanislaus River to south of the Merced River and bounded on the northeast by the Sierra Nevada foothills and the southwest by the San Joaquin River. The model grid is oriented parallel to the valley axis, 37 degrees west of due north (fig. 15). The model area extends $61.2 \mathrm{~km}$ along the valley axis and $54.8 \mathrm{~km}$ from the Coast Ranges to the Sierra Nevada foothills, although the area west of the San Joaquin River is not simulated. Each model cell is $400 \mathrm{~m}$ by $400 \mathrm{~m}$, and the grid has 153 rows and 137 columns.

The regional model layering was designed as a series of wedges to generally represent the regional dip of the sediments (fig. 16). Sixteen model layers were defined, ranging in thickness from 0.5 to $16 \mathrm{~m}$ above the Corcoran Clay (excluding the uppermost model layer) and from 20 to $74 \mathrm{~m}$ below the Corcoran Clay. Layer thicknesses generally were designed to increase with depth and decreasing availability of sediment texture data. The top of the uppermost model layer represents the land surface, and the bottom is a smoothed version of the land surface; the thickness ranges from 1 to $40 \mathrm{~m}$. The thickest cells in the uppermost layer are near the foothills and generally are not saturated. The thicknesses of layers 2 through 7 were assigned as a percentage of the thickness of materials between layer 1 and the top of the Corcoran Clay (10, 10, 15, 20, 20, and 25 percent of that thickness, respectively).

Layer 8 represents the Corcoran Clay, where present, the top surface of which was a smoothed rendition constrained by data from driller's logs. The thickness of the Corcoran Clay varies spatially as determined by Page (1986) and from analysis of logs, and ranged from 3 to $43 \mathrm{~m}$. A thickness of $5 \mathrm{~m}$ was specified in layer 8 where the Corcoran Clay was not present. The thickness of layers 9-16 was assigned as a percentage of the thickness of materials between the bottom of the Corcoran Clay and the bottom of the model. Layers 9-16 were 10, 10, $10,10,10,15,15$, and 20 percent of that thickness, respectively. The bottom of the model was an artificial surface that loosely represented topographic variability and the general dip of the Corcoran Clay. The total thickness of the wedge-shaped model ranges from about 220 to $430 \mathrm{~m}$.

\section{Local Model}

The local model is located within the regional model area, straddles the Merced River (fig. 17), and is oriented the same as the regional model (fig. 1). The active model area is about $17 \mathrm{~km}^{2}$. Each model cell is $40 \mathrm{~m}$ by $40 \mathrm{~m}$, and the grid has 110 rows and 140 columns. There are 110 flat-lying layers, each $0.5 \mathrm{~m}$ thick, with a maximum altitude of $34.5 \mathrm{~m}$. The layer thickness was the same as that for the TProGS grid, which was determined on the basis of the thickness of hydrofacies recorded in USGS geologic logs. The bottom of the model coincides with the top of the Corcoran Clay. 


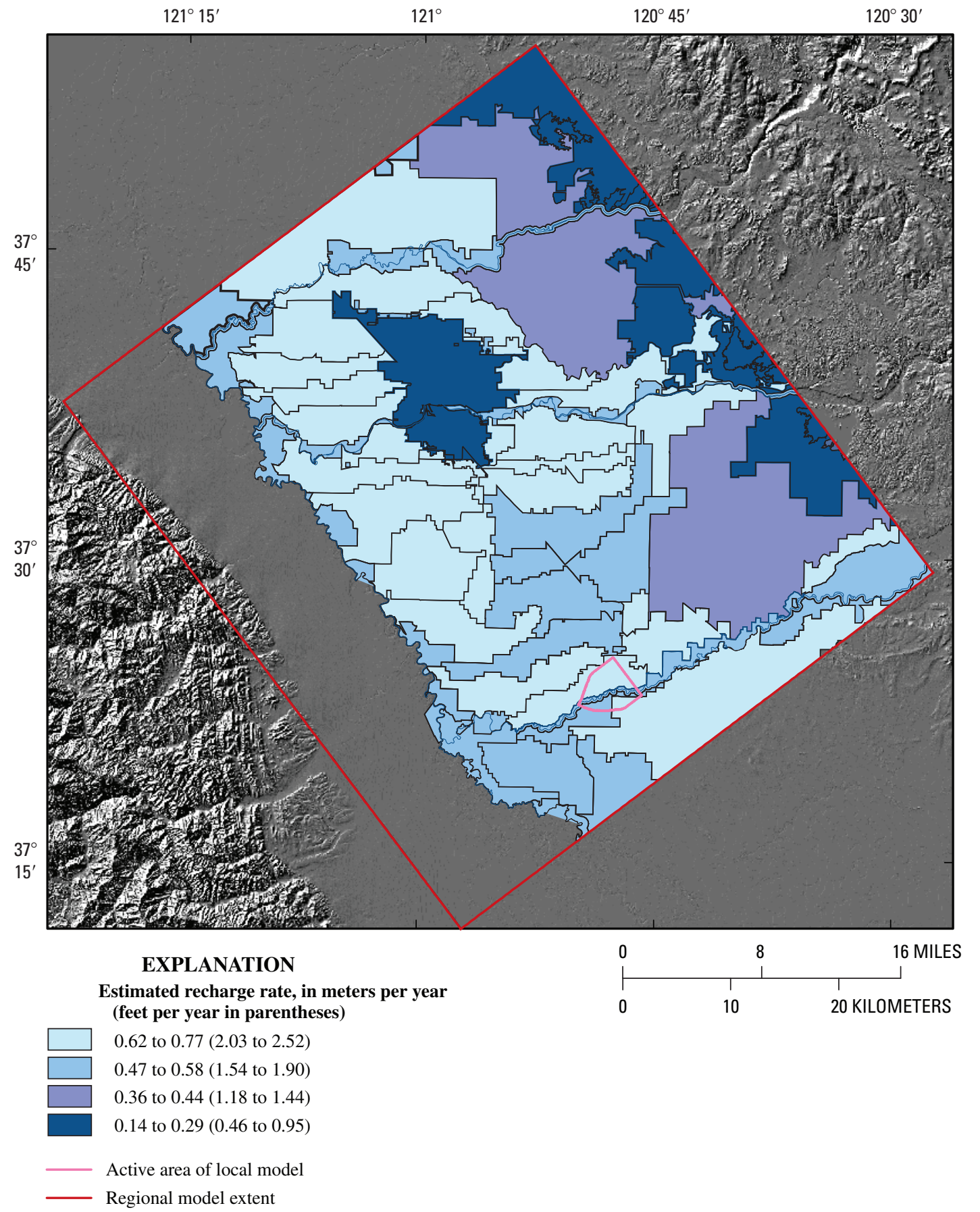

Figure 13. Estimated rates of recharge for subareas of regional model, water year 2000, San Joaquin regional study area, California.

Modified from Burow and others (2004). 


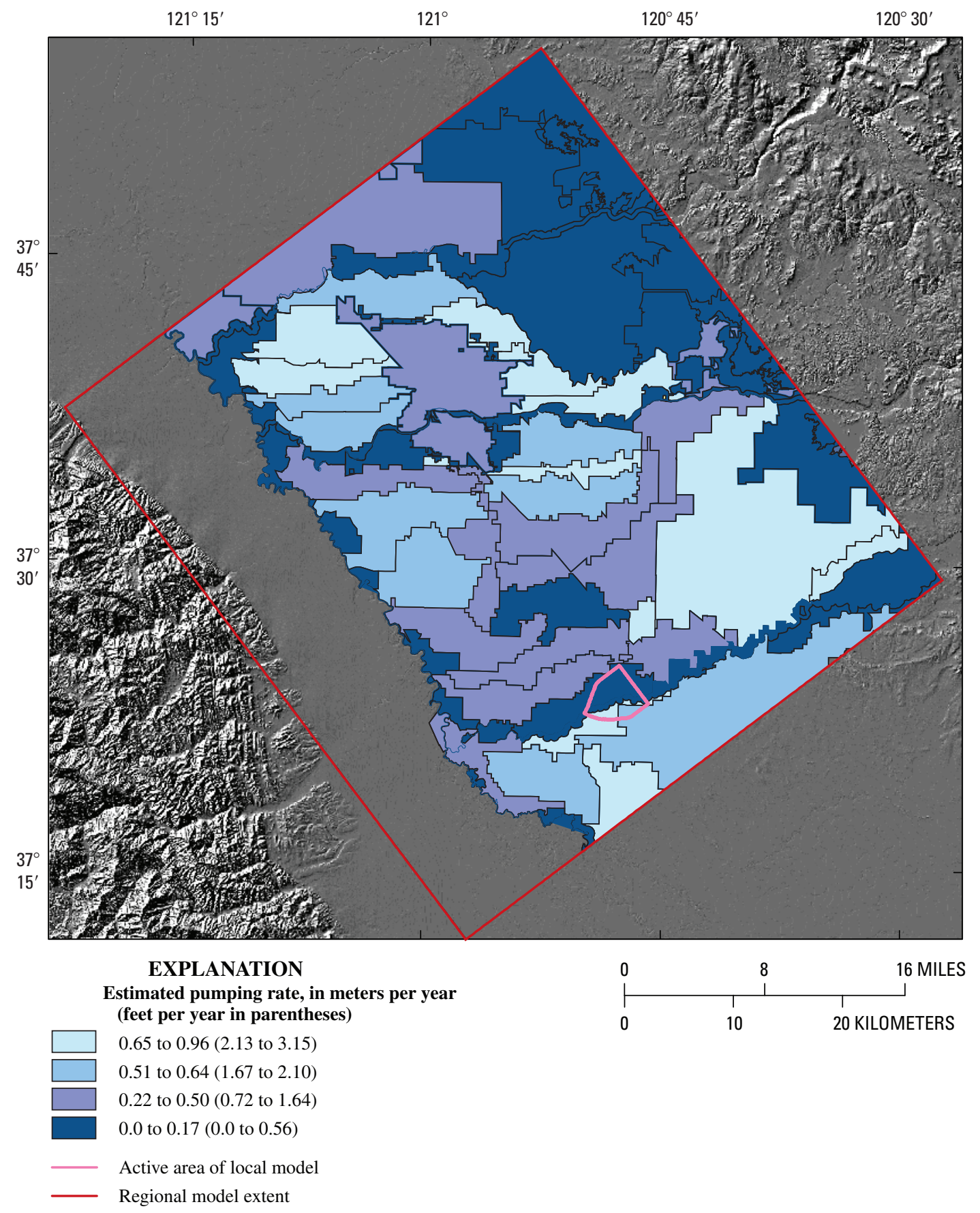

Figure 14. Estimated rates of ground-water pumping for subareas of regional model, water year 2000, San Joaquin regional study area, California.

Modified from Burow and others (2004). 


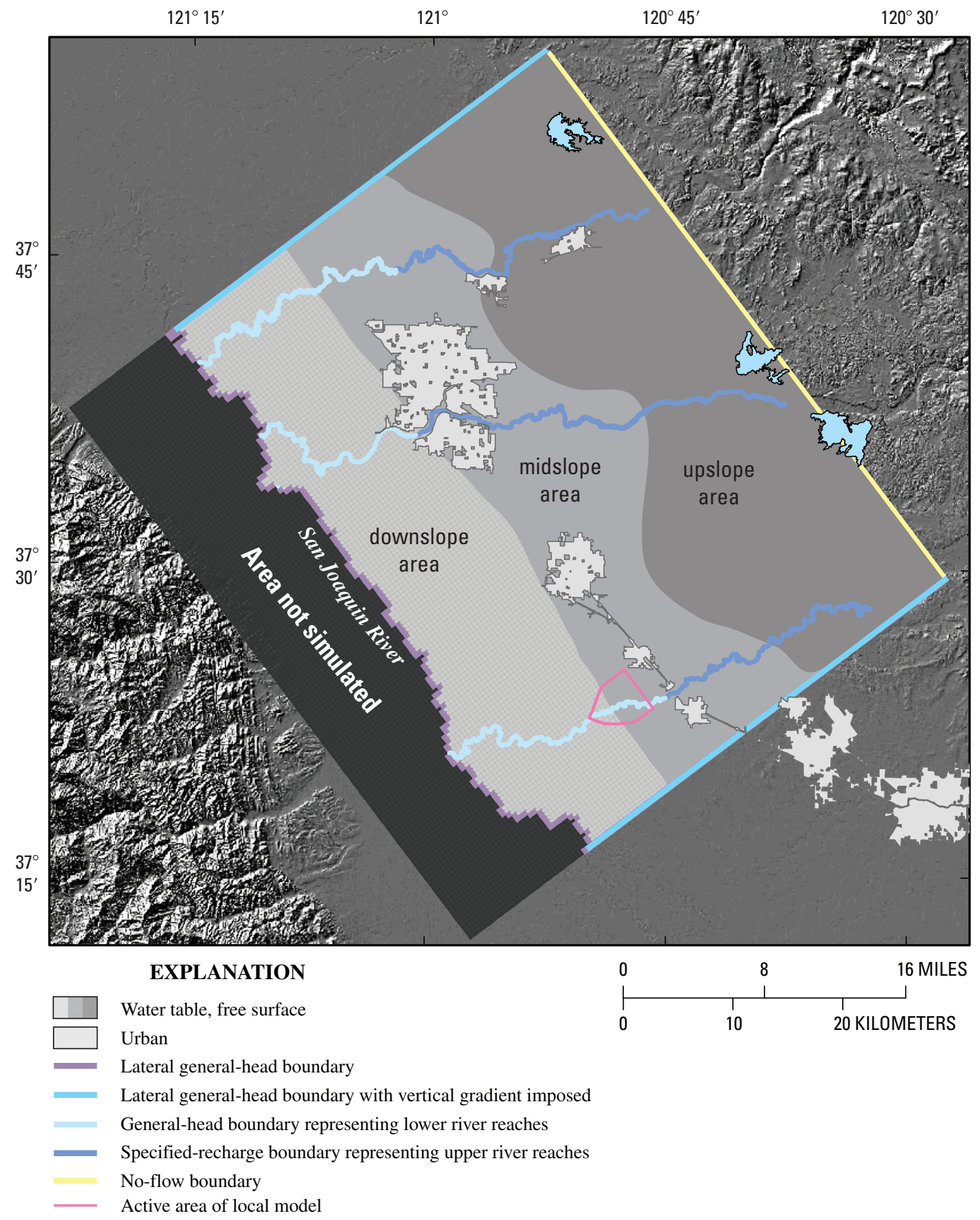

Figure 15. Model extent, boundary conditions, and extent of the downslope, midslope, and upslope areas for the regional model, San Joaquin regional study area, California. 


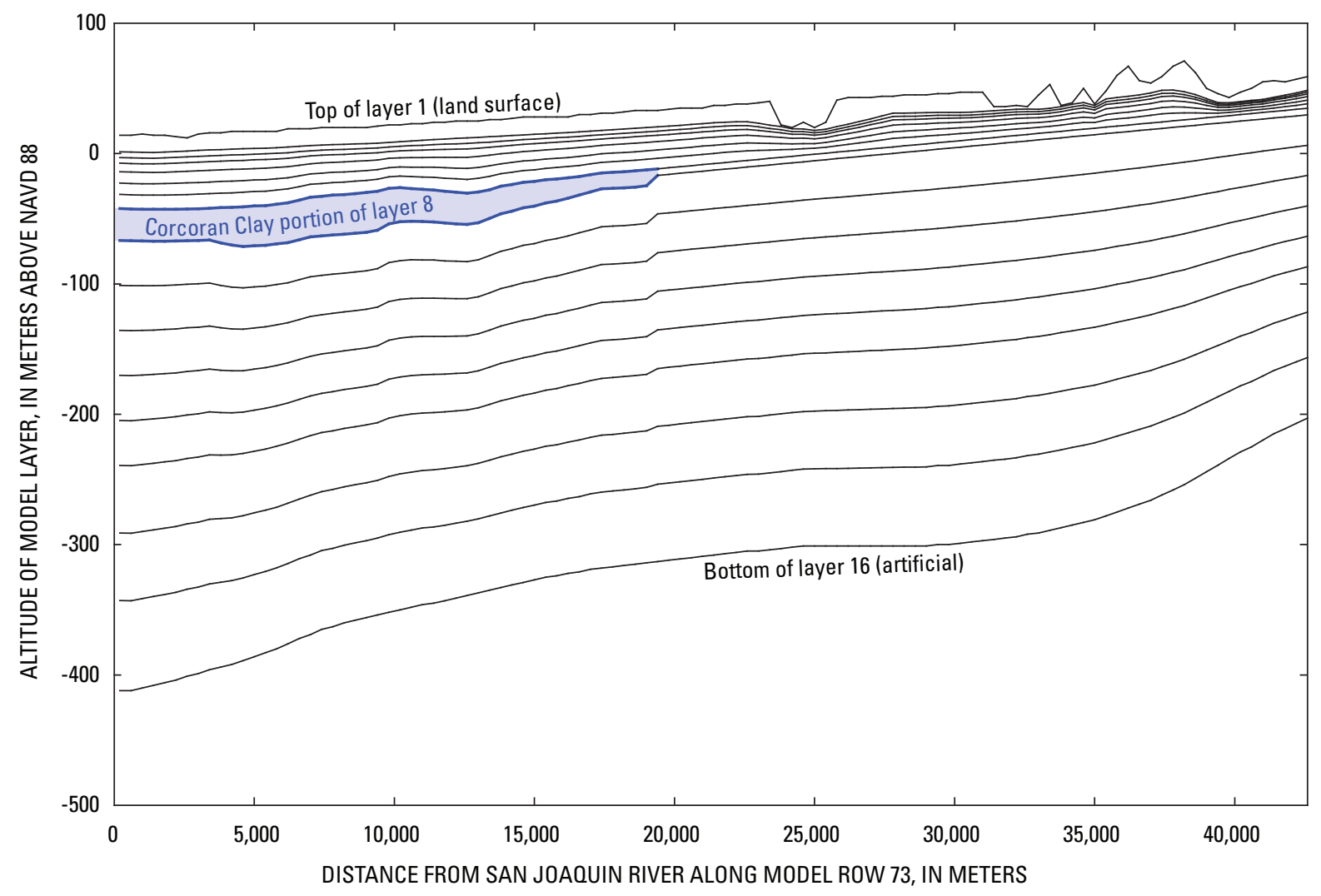

Figure 16. Vertical discretization of regional model along row 73, San Joaquin regional study area, California. Location of row 73 is shown on figure 1.

\section{Boundary Conditions and Model Stresses}

\section{Regional Model}

Lateral boundary conditions in the regional model are no-flow along the Sierra Nevada foothills and general-head elsewhere (fig. 15). The general-head boundaries were specified using a water-level map (fig. 8), typical vertical hydraulic gradients calculated from measured water levels, and hydraulic-conductivity estimates for each cell along the boundary. Initially, no vertical gradients were imposed along the lateral boundaries, but measured water levels in Modesto, where pumpage is known, could not be simulated using justifiable ranges of aquifer hydraulic parameters. Therefore, gradients were later imposed along the northwestern and southeastern edges of the regional model grid during model calibration. A downward hydraulic gradient of 0.05 was assigned from layers 1 through 9, the latter being the approximate average location of well perforations in the region. Below layer 9, the same gradient was assigned in an upward direction; the maximum head below layer 9 was constrained to that of the water table in the same row and column of the model grid.

The southwestern boundary of the regional model coincides with the San Joaquin River, and was simulated as a lateral general-head boundary; all cells west of the river are inactive. This configuration allows for known cross-valley flow beneath the San Joaquin River (Belitz and Phillips, 1995; Phillips and others, 1991). Water-level data and production wells are sparse near this boundary; therefore, a vertical gradient was not specified. Heads in all cells below the river were set to $0.1 \mathrm{~m}$ above river stage on the basis of previous work in the upper $30 \mathrm{~m}$ of the aquifer system along the river, which showed predominantly gaining conditions during an 11-month period in 1988-89 (Phillips and others, 1991).

The upper boundary of the regional model was simulated as the water table, and the lower model boundary was simulated as no-flow. The lower model boundary was arbitrarily located far below the deepest wells, and significant vertical flow at that depth was considered unlikely.

Agricultural return flow, infiltration of precipitation, reservoir leakage, and inflow from rivers recharge the regional aquifer. Agricultural return flow, infiltration of precipitation, and private agricultural ground-water pumping were estimated in the water-budget analysis. The two recharge estimates from the water-budget analysis were summed for each waterbudget subarea, and this recharge was distributed evenly to the uppermost active model layer within each subarea. 


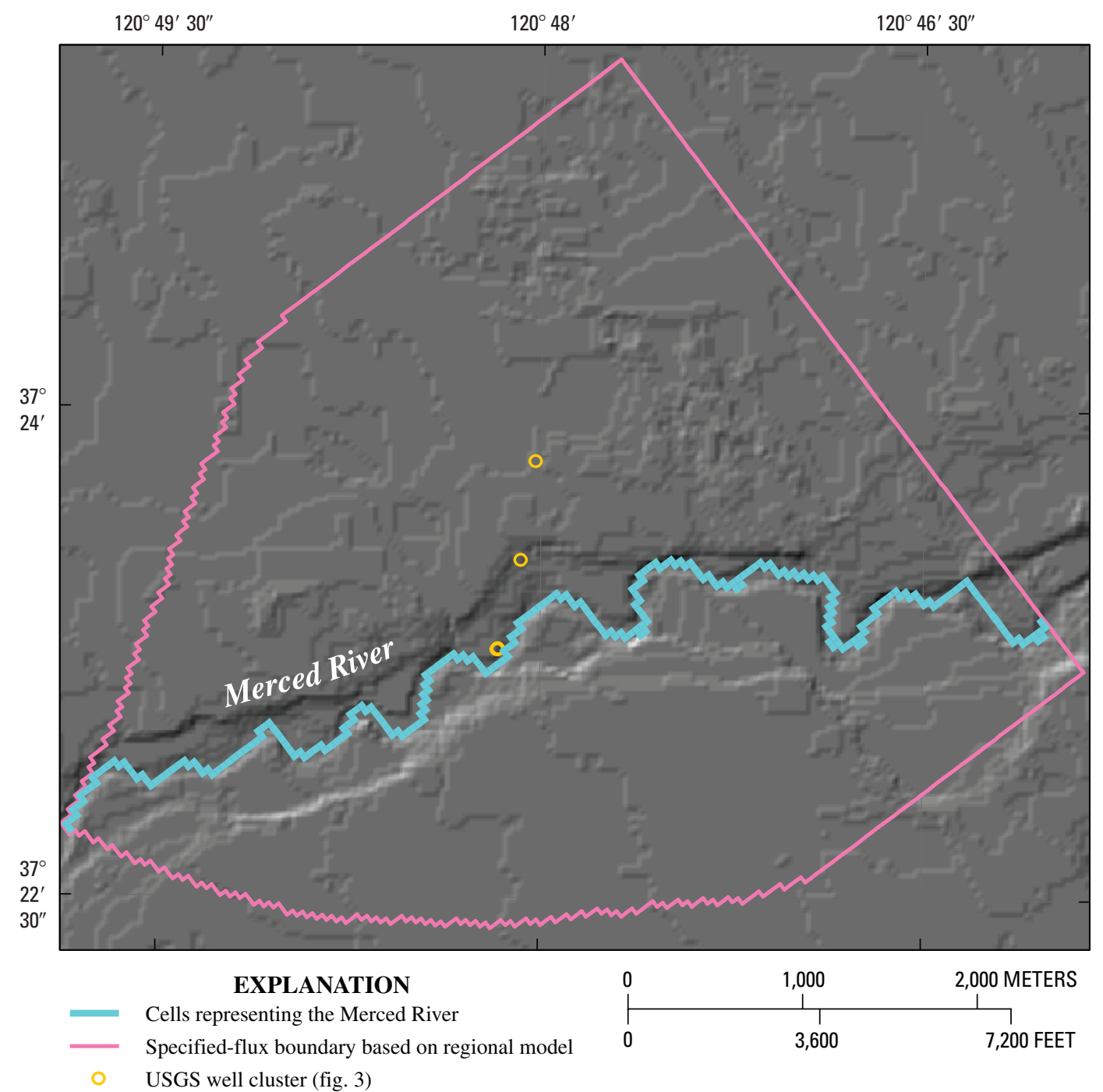

Figure 17. Extent of active area and boundary conditions for the local model, San Joaquin local study area, California.

Ground-water discharges to pumping wells, rivers, and evaporation were simulated. Private agricultural pumping was distributed laterally within water-budget subareas, assuming an average well spacing of 1,200 m (every 3 cells). Measured pumpage in urban areas and irrigation districts was withdrawn from cells that contained the pumping wells. The vertical distribution of private agricultural pumping was estimated using the average screened interval of irrigation wells in each subarea. Pumpage was distributed vertically by weighting transmissivity to layers intersected by a well screen. Measured pumpage also was distributed in this manner.

Interaction between ground water and surface water was simulated as reservoir leakage, gaining reaches, and losing reaches of the four rivers. There were three significant reservoirs along the northeastern boundary of the regional model: Woodward, Modesto, and Turlock, from north to south (fig. 1). These reservoirs were approximately equal in size, and an estimate of leakage rates (about 67,600 to $84,500 \mathrm{~m}^{3} / \mathrm{d}$ ) was available only for a 3-month period for the Modesto Reservoir (Walter Ward, Modesto Irrigation District, oral commun., 2002). Leakage rates for the other two reservoirs were assumed to be similar to that for the Modesto Reservoir. The Reservoir package (Fenske and others, 1996) in MODFLOW-2000 was used to simulate the reservoirs, which requires specification of reservoir stage, and information for calculating the conductance of the reservoir bottom. The stage was estimated from topographic maps, and the conductance terms were adjusted to approximate the assumed leakage rate. 
The four rivers in the study area were represented in the model as a combination of general-head and specifiedflux cells. General-head cells were used where the river was potentially connected to the water table; this allowed flow into and out of the river. The river stage was estimated using streamgage data and topography, and the riverbed conductance was calculated using the estimated vertical hydraulic conductivity by cell, the approximate river width, and an assumed riverbed thickness of $1 \mathrm{~m}$. Recharge from the river was specified in model cells where the river was disconnected from the water table. This value $(0.005 \mathrm{~m} / \mathrm{d}$ per cell $)$ is poorly constrained and was not adjusted during calibration.

Bare-soil evaporation from the water table was simulated where the water table was within $2.1 \mathrm{~m}$ of the land surface. The maximum evaporation rate of $1.6 \mathrm{~m} / \mathrm{yr}$ was specified at the land surface, and a linear decrease to zero at $2.1 \mathrm{~m}$ below land surface was simulated on the basis of previous work in a nearby area (Belitz and Phillips, 1995).

\section{Local Model}

The location of the lateral boundaries was based roughly on flow lines associated with the water table. The northeastern boundary was at a shallow angle to a flow line, and the northwestern and southern boundaries approximated flow lines converging at the Merced River (fig. 17). Although two of these lateral boundaries approximated flow lines at the water table, flow directions vary with depth; therefore, lateral boundary conditions in the local model were specified fluxes derived from lateral flows simulated in the regional model. The estimated local distribution of sediment types was translated into sediment texture values for overlapping regional model cells, thus minimizing incompatible flux/sediment combinations at the regional/local interface. Cell-by-cell boundary fluxes for the local model were calculated from those for adjacent larger cells in the regional model by using a hydraulic-conductivity-weighted distribution.

The upper boundary of the local model was the water table, and the lower boundary was general-head, allowing vertical flow through the Corcoran Clay. The hydraulic head beneath the Corcoran Clay was specified at $19.9 \mathrm{~m}$, which was the average value from 2004 to 2005 measured in a USGS well completed beneath the clay at the lower end of the well transect. The conductance of the general-head boundary was calculated using the calibrated vertical hydraulic conductivity of the Corcoran Clay from the regional model and a constant thickness $(18 \mathrm{~m})$ determined from the geologic log for the USGS well.

Stresses in the local model included recharge from agricultural return flow, infiltration of precipitation, and inflow through the boundaries; and discharge from outflow to the Merced River and through the boundaries. The lateral boundaries have been discussed, and there was no substantial ground-water use in the local study area because a canal provides irrigation water. Recharge from agricultural return flow was estimated using the crop demand calculated in the regional water-budget analysis and a variable consumptive use of applied water estimated from the irrigation method (California Department of Water Resources, 2001a) used on each parcel (fig. 18). Given that most of the local study area is cultivated, topographic slopes are shallow, fields generally are terraced, and precipitation falls primarily during the period when crops are dormant, it was assumed that about 60 percent of rainfall became recharge. The average estimated net recharge flux across the land surface in the local model area was $0.45 \mathrm{~m} / \mathrm{yr}$, one third of which was from precipitation. The average local estimated recharge was 10 percent lower than that for the regional model in the same area.

Interaction of ground water with the Merced River (discharge) was simulated in the local model using the River package in MODFLOW-2000 (Harbaugh and others, 2000). The river stage at the study reach was assigned the average of continuous on-site measurements from 2003 to 2005. This stage at the study reach was extrapolated for upstream and downstream river cells on the basis of the topographic gradient of the river channel. The conductance of the river bed was calculated using the approximate area of the bed, an assumed bed thickness of $1 \mathrm{~m}$, and an assigned riverbed vertical hydraulic conductivity of $30 \mathrm{~m} / \mathrm{d}$.

\section{Estimation of Aquifer Hydraulic Properties}

\section{Regional Model}

Hydraulic conductivity was distributed using sediment texture, the same method as that used for a previous groundwater flow model of the central western San Joaquin Valley (Belitz and Phillips, 1995; Phillips and Belitz, 1991). This method uses the estimated sediment texture for each model cell and horizontal and vertical hydraulic conductivity estimates for each textural end member.

A hydraulic conductivity value was specified for the Corcoran Clay $\left(K_{\text {corc }}\right)$, which was assumed to be isotropic. For the remaining aquifer-system materials, horizontal hydraulic conductivities were calculated using the coarse-grained $\left(K_{\text {coarse }}\right)$ and fine-grained $\left(K_{\text {fine }}\right)$ lithologic end members and the distribution of sediment texture. The lithologic end members were specified for two lithologic subareas: the older fan deposits along the northeastern edge of the model (the upslope area in fig. 15) and everywhere else. Horizontal hydraulic conductivity $\left(K_{h}\right)$ was calculated for each cell in the model using the arithmetic mean:

$$
K_{h}=K_{\text {coarse }} \times F_{\text {coarse }}+K_{\text {fine }} \times F_{\text {fine }}
$$

where $F_{\text {coarse }}$ is the fraction of coarse-grained sediment in a cell, estimated from sediment texture data as described earlier in this report, and

$F_{\text {fine }}$ is the fraction of fine-grained sediment in a cell $\left(1-F_{\text {coarse }}\right)$. 


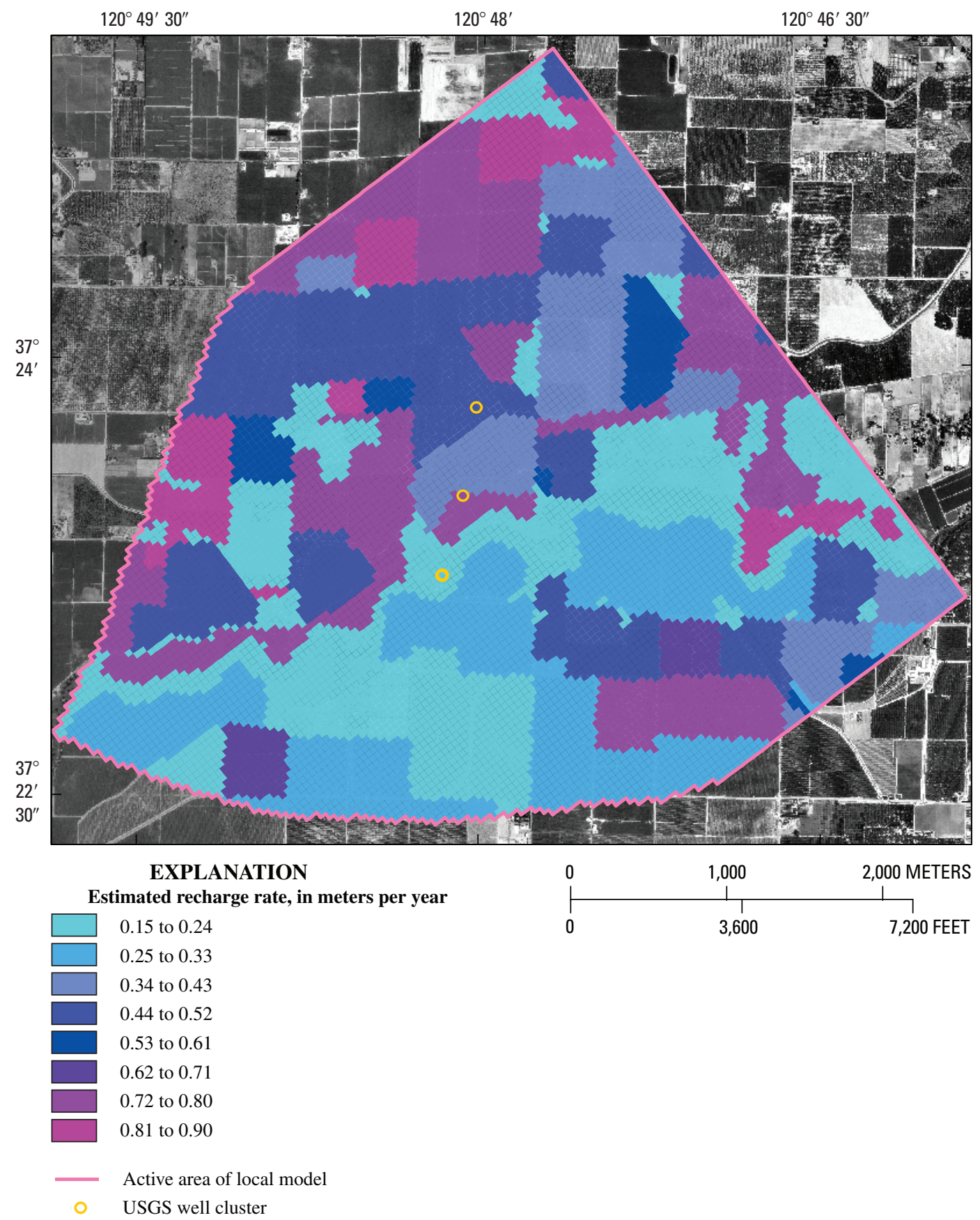

Figure 18. Estimated rates of recharge for the local model, water year 2000, San Joaquin local study area, California. 
Vertical hydraulic conductivity between model layers $\left(K_{v}\right)$ either was set to $K_{\text {corc }}$, if the Corcoran Clay was present within one of the layers, or was calculated using the harmonic mean:

$$
K_{v}=\frac{1}{\frac{F_{\text {coarse }}}{K_{\text {coarse }}}+\frac{F_{\text {fine }}}{K_{\text {fine }}}}
$$

where $F_{\text {coarse }}$ is the fraction of coarse-grained sediment between layer midpoints, and

$F_{\text {fine }}$ is the fraction of fine-grained sediment between layer midpoints.

The calibrated value of $K_{\text {corc }}$ was $1.3 \times 10^{-3} \mathrm{~m} / \mathrm{d}$ and that for $K_{\text {fine }}$ was $8 \times 10^{-3} \mathrm{~m} / \mathrm{d}$. The calibrated value of $K_{\text {coarse }}$ varied by lithologic subarea: $53 \mathrm{~m} / \mathrm{d}$ for the older fan deposits and 80 $\mathrm{m} / \mathrm{d}$ for the remaining area. The resulting values of $K_{h}$ and $K_{v}$ are summarized in figure 19. The distributions of $K_{h}$ and $K_{v}$ are the same as those for the sediment texture (fig. 5).

\section{Local Model}

Effective hydraulic conductivity in the three principal directions of each of 200 texture realizations was estimated using 600 simulations. These simplified simulations were used to compute flow in each principal direction for each realization. Constant-head boundaries were assigned at the up-gradient and down-gradient faces to produce an arbitrary hydraulic gradient of 0.0009 , and no stresses were imposed. Isotropic hydraulic conductivities were assigned: $0.08 \mathrm{~m} / \mathrm{d}$ for the clay hydrofacies, $2 \mathrm{~m} / \mathrm{d}$ for silt, $24 \mathrm{~m} / \mathrm{d}$ for silty sand, $160 \mathrm{~m} / \mathrm{d}$ for sand, and $0.00008 \mathrm{~m} / \mathrm{d}$ for the Corcoran Clay.

Five of the TProGS-generated realizations of the threedimensional distribution of hydrofacies within the local model were chosen for calibration and sensitivity. This subset of realizations was selected on the basis of a relative ranking of the bulk flow properties in the $\mathrm{X}, \mathrm{Y}$, and $\mathrm{Z}$ directions. Four were chosen to represent the extremes:

1. The maximum sum of flow in the $x, y$ and $z$ directions (highest effective conductivity);

2. The minimum sum of flow in the $x, y$ and $z$ directions (lowest effective conductivity);

3. The maximum of $(\mathrm{z}$ flow $-(\mathrm{x}$ flow $+\mathrm{y}$ flow $))$ (least domain-scale anisotropy); and

4. The minimum of $(\mathrm{z}$ flow $-(\mathrm{x}$ flow $+\mathrm{y}$ flow $))$ (greatest domain-scale anisotropy).

A fifth realization was chosen randomly for use in developing the local model, and ultimately was used in the calibrated model. Of the 200 realizations, this ranked $54^{\text {th }}, 48^{\text {th }}$, and $33^{\text {rd }}$ for flow in the $\mathrm{X}, \mathrm{Y}$, and $\mathrm{Z}$ directions, respectively. Figure 20 shows one view of the vertical distribution of hydrofacies for this realization.
To simplify model calibration, the three hydrofacies in the Holocene deposits associated with the incised river channel were assumed to be hydraulically equivalent to the same hydrofacies in the Pleistocene deposits. Therefore, the total remained at four hydrofacies: sand, silty sand, silt, and clay. The overall proportions of these facies are as shown in the Pleistocene section in table 1 . The calibrated and specified values of horizontal and vertical hydraulic conductivity associated with each hydrofacies are shown in table 3.

\section{Model Calibration and Sensitivity}

\section{Regional Model}

Calibration of the regional model consisted of a systematic application of the parameter estimation method (described in the "Aquifer Hydraulic Properties" section in this report) to narrow the range of possible solutions. This was followed by manual adjustments to best match the highest-quality waterlevel measurements in midslope areas while simultaneously honoring the overall conditions in upslope and downslope areas. $K_{\text {coarse }}$ and $K_{\text {fine }}$ were varied systematically for a given value of $K_{\text {corc }}$, which was adjusted to roughly match vertical gradients across the Corcoran Clay (assumed to be isotropic). Simulated hydraulic heads were compared to measured water levels in 49 wells representing various parts of the aquifer system, including 22 wells installed and monitored by the USGS. The resulting error distributions constrained the parameter set and constitute a sensitivity analysis of these parameters.

Wells used to calibrate the regional model were divided into several categories. The first category included the USGS wells and associated measurements, which were considered the highest quality because of the short screened intervals $(0.6$ to $3 \mathrm{~m}$ ) and hourly measurements during 2003-2005. Most of these wells are in midslope areas in and near Modesto and the local study area. These wells are multi-depth completions, and thus were used to evaluate simulated vertical gradients as well as simulated hydraulic heads. Two other key categories of wells were defined geographically. The downslope area where the water table is shallow was represented by 17 wells, most of which were $4.6 \mathrm{~m}$ deep and monitored on a monthly basis. Data from these wells were ranked second highest in overall quality. The upslope area northeast of Modesto and Turlock was represented by 11 wells, including one USGS well in Eastside Water District. The final well used to calibrate the regional model was a USGS well screened below the Corcoran Clay at the lower end of the USGS well transect in the local study area. 
Horizontal Hydraulic Conductivity

Vertical Hydraulic Conductivity
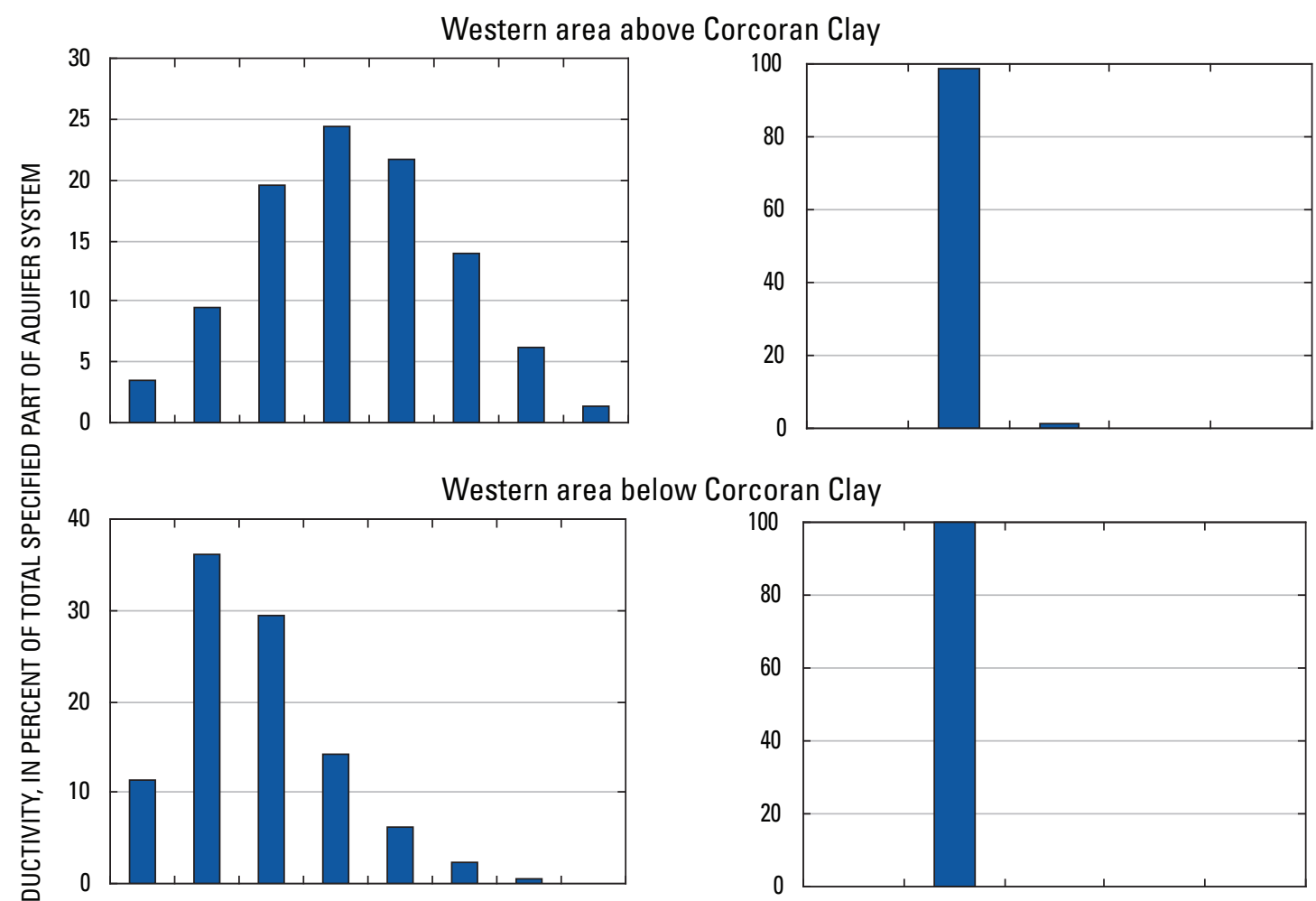

Eastern area, entire thickness
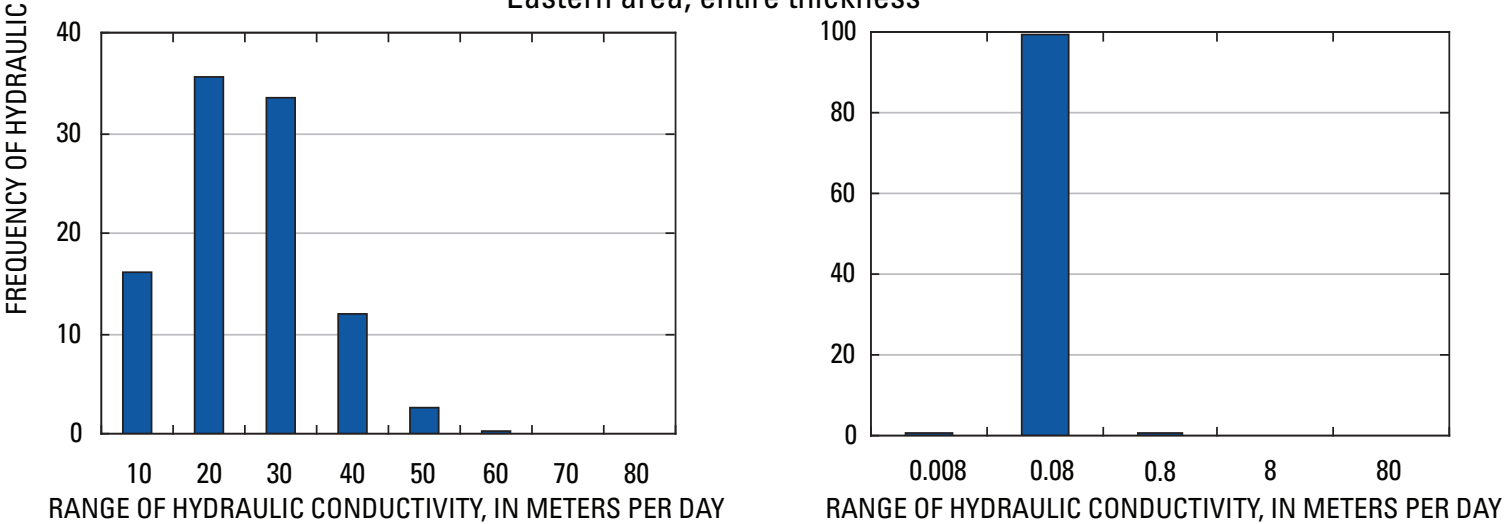

Figure 19. Frequency of estimated horizontal and vertical hydraulic conductivity for the upslope (eastern) and downslope (western) alluvial deposits, San Joaquin regional study area, California.

Model error was quantified by average error and the rootmean-square error (RMSE):

$$
R M S E=\sqrt{\sum_{i=1}^{n} \frac{\left[h_{\text {meas }}-h_{\text {sim }}\right]_{i}^{2}}{n}}
$$

where $h_{\text {meas }}$ is measured water level,

$h_{\text {sim }}$ is simulated hydraulic head,

$i \quad$ is the summation index, and

$n$ is the number of measurements.
The RMSE is a measure of error magnitude, and average error indicates whether simulated hydraulic heads were, overall, higher or lower than measured water levels. The RMSE and average error calculations were used to estimate the range of $K_{\text {coarse }}$ and $K_{\text {fine }}$ values that generated parameter distributions with the lowest error for the conceptual model described herein. RMSE and average error values were calculated for 100 simulations at a time, representing progressively narrower ranges of $K_{\text {coarse }}$ and $K_{\text {fine }}$. Results from each group of 100 simulations were plotted as error surfaces describing model fit with respect to hydraulic heads for various sets of calibration wells (fig. 21). Each plot in figure 21 shows the error surface 


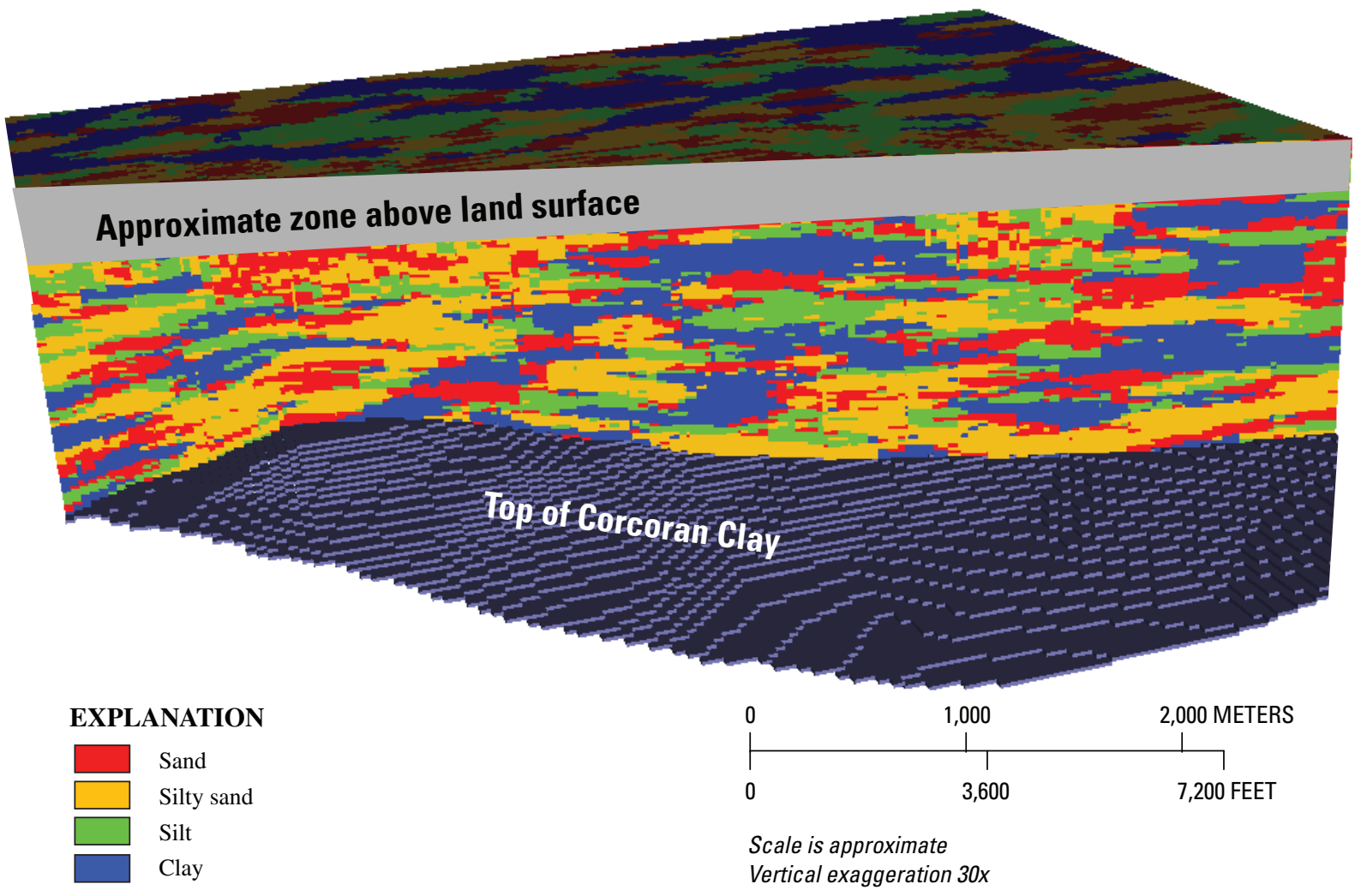

Figure 20. Vertical section roughly parallel to the Merced River showing distribution of hydrofacies used in calibrated local model, San Joaquin local study area, California.

Table 3. Calibrated and specified hydraulic conductivity values for the local model, San Joaquin local study area, California.

[Bold values are calibrated]

\begin{tabular}{lcc}
\hline Hydrofacies & $\begin{array}{c}\text { Horizontal } \\
\text { hydraulic } \\
\text { conductivity, } \\
\text { in meters per day }\end{array}$ & $\begin{array}{c}\text { Vertical } \\
\text { hydraulic } \\
\text { conductivity, } \\
\text { in meters per day }\end{array}$ \\
\hline Sand & $\mathbf{8 0}$ & 40 \\
Silty sand & $\mathbf{3 0}$ & 6 \\
Silt & $\mathbf{8}$ & 1 \\
Clay & $\mathbf{0 . 3}$ & $\mathbf{0 . 1 5}$ \\
\hline
\end{tabular}


for simulated hydraulic heads at the locations of USGS wells or wells representing the upslope and downslope parts of the aquifer system. The model was numerically stable over a wide range of parameter values, but numerical stability decreased as values of $K_{\text {coarse }}$ and $K_{\text {fine }}$ decreased.

The error surfaces constrain $K_{\text {coarse }}$ and $K_{\text {fine }}$ to the lower central region of the plot and indicate that relatively high values of $K_{\text {coarse }}$ and low values of $K_{\text {fine }}$ provide the best solution for the given conceptual model (fig. 21). Simulated values compare well to measurements in the USGS wells, and the error surface defines a zone of minimum error. However, the error surfaces for upslope and downslope areas indicate greater error, no minima near that of the USGS wells, and slope in opposite directions. This indicates there is some error in the conceptual model and (or) the water-level data for the upslope and (or) downslope areas. Subsequent manual calibration efforts focused on matching vertical gradients calculated from measurements in the USGS wells while minimizing error for the downslope wells and key upslope wells and staying within the zone of minimum error for the USGS wells. Results indicate that $K_{\text {coarse }}$ and $K_{\text {fine }}$ values of about 80 and $8 \times 10^{-3} \mathrm{~m} / \mathrm{d}$, respectively, generate the best-fit parameter distribution. The associated value of $K_{\text {corc }}\left(1.3 \times 10^{-3} \mathrm{~m} / \mathrm{d}\right)$ was adjusted to reasonably match vertical hydraulic gradients calculated from water levels measured in wells screened above and below the Corcoran Clay.

A hydraulic conductivity of $80 \mathrm{~m} / \mathrm{d}$ is within the typical range of that for clean sand and a hydraulic conductivity of $8 \times 10^{-3} \mathrm{~m} / \mathrm{d}$ is within the range of silty clay (Freeze and Cherry, 1979). Both lithologies are common in the study area and reasonably represent the lithologic end members. Permeameter tests of cores from the Corcoran Clay indicate vertical hydraulic conductivities ranging from $1 \times 10^{-6}$ to $3 \times 10^{-6} \mathrm{~m} / \mathrm{d}$ (Page, 1977). Previous investigations, however, indicate wells screened across the Corcoran Clay have increased the effective vertical hydraulic conductivity by orders of magnitude by allowing the clay to be short circuited (Williamson and others, 1989; Belitz and Phillips, 1995). The calibrated value of $K_{\text {corc }}$ from this study $\left(1.3 \times 10^{-3} \mathrm{~m} / \mathrm{d}\right)$ is consistent with these previous findings. The value estimated by Belitz and Phillips (1995) for an area southwest of the regional model is one order of magnitude lower than that estimated by this study. However, the greater depth of burial of the Corcoran Clay in that area (about 100-240 m) and widespread aquifer-system compaction may have caused a substantial decrease in its vertical hydraulic conductivity.

\section{Regional Simulated Hydraulic Heads}

The simulated water table (fig. 22) resembles the contours of measured water levels depicted in figure 8. A simple method of assessing overall model fit is to plot the simulated head values against the measured water levels. For a perfect fit, all points should fall on the 1:1 diagonal line. Figure 23 is a plot of the simulated heads versus measured water levels for the regional model area and indicates good overall model fit.
Simulated hydraulic heads closely matched measured water levels in USGS wells in the midslope areas, as indicated by an average residual of $0.3 \mathrm{~m}$ and a RMSE of $0.8 \mathrm{~m}$. In the downslope area, simulated hydraulic heads in the area underlain by a shallow water table reasonably matched measured heads; the average error was $1.5 \mathrm{~m}$ and the RMSE was $3.4 \mathrm{~m}$. Much of this error, and the primary source of the positive average error, was associated with two wells on the northeastern side of this area within Turlock Irrigation District, indicating that the simulated ground-water divide was slightly downslope of the actual divide. Water levels in the upslope area were also simulated well; the average error was $1.2 \mathrm{~m}$ and the RMSE was $2.1 \mathrm{~m}$.

The average error for all wells was $0.9 \mathrm{~m}$; the errors ranged from -1.7 to $9.6 \mathrm{~m}$ (fig. 22) and the standard deviation was $2.1 \mathrm{~m}$. The associated RMSE was $2.3 \mathrm{~m}$, about 7 percent of the range of head observations in the aforementioned set of wells $(32.9 \mathrm{~m})$. The errors for the USGS wells were randomly distributed around zero, and those for the upslope and downslope areas were skewed positive by a few measurements in wells near the ground-water divide and within the cone of depression in the eastern part of the regional study area (fig. 22). Simulated values generally were lower than measured values in these areas, although the error for the only USGS well in Eastside Water District was very small ( $-0.4 \mathrm{~m})$.

\section{Local Model}

The local model was calibrated using a combination of the Sensitivity and Parameter-Estimation Processes in MODFLOW-2000 (Hill and others, 2000) and manual adjustments. Hourly water-level measurements in 11 USGS wells along a transect north of the Merced River (fig. 11) were averaged on a water-year basis for model calibration. The adequacy of the head-based calibration was evaluated by using computed fluxes to compare simulated and measured concentrations of sulfur hexafluoride, an environmental tracer.

Wells used to calibrate the local model included all 4 at the upper end of the well transect, the 3 deepest wells at the middle site, and 4 wells at the lower end (lower_9, lower_15, lower_25, lower_29) (fig. 3). Hourly water-level measurements were recorded in these wells for 1 to 1.6 years, and annual averages of these measurements were used for model calibration. Data from the shallowest and deepest wells at these sites are shown in figure 11. These well clusters were used to evaluate simulated vertical gradients as well as simulated hydraulic heads.

A subset of the horizontal and vertical hydraulic conductivity values of the four textural categories defined earlier were adjusted during calibration of the local model. Because the model was insensitive to the riverbed conductance, it was not adjusted during calibration. Recharge estimates, the vertical hydraulic conductivity of the Corcoran Clay, and boundary fluxes also were not adjusted during calibration. 


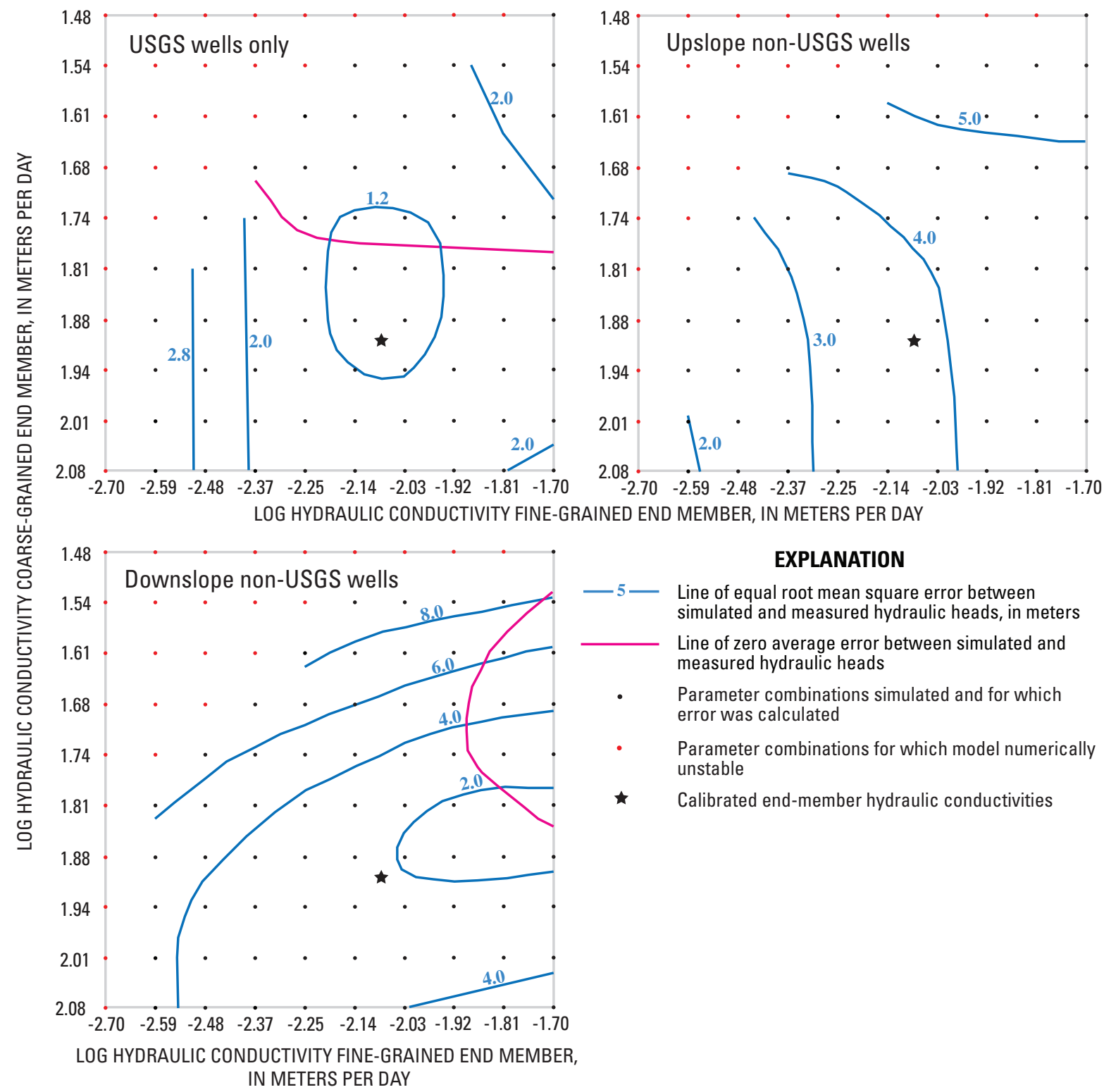

Figure 21. Error surfaces used to calibrate, and calibration results for, the regional model, San Joaquin regional study area, California.

USGS, U.S. Geological survey.

The Sensitivity Process in MODFLOW-2000 (Hill and others, 2000) identifies the sensitivity of computed values at the locations of measurements to changes in model parameters. It was used to identify which hydraulic conductivity parameters to include in the Parameter Estimation Process (Hill and others, 2000) and to adjust during subsequent manual calibration. Results of the Sensitivity Process indicate that the local model was most sensitive to the horizontal hydraulic conductivities of the sand, silty sand, and silt hydrofacies, listed here in declining order of sensitivity (fig. 24). The local model was moderately sensitive to the vertical hydraulic conductivity of the clay facies, and essentially insensitive to the remaining hydraulic conductivities. Results also showed that sensitivity was greatest at the upper end of the well transect (fig. 25) because, as in the real system, water levels near the Merced River are controlled primarily by the river stage, not by irrigation.

The most sensitive hydraulic conductivity parameters were estimated initially using the Parameter Estimation Process (Hill and others, 2000), followed by manual adjustments. The Parameter Estimation Process minimizes a weighted least-squares objective function, thereby finding the optimal solution to the problem, assuming it converges numerically. The average water levels used as observations were not weighted, because identical equipment and methods were used to derive the measurements. The Parameter Estimation Process 


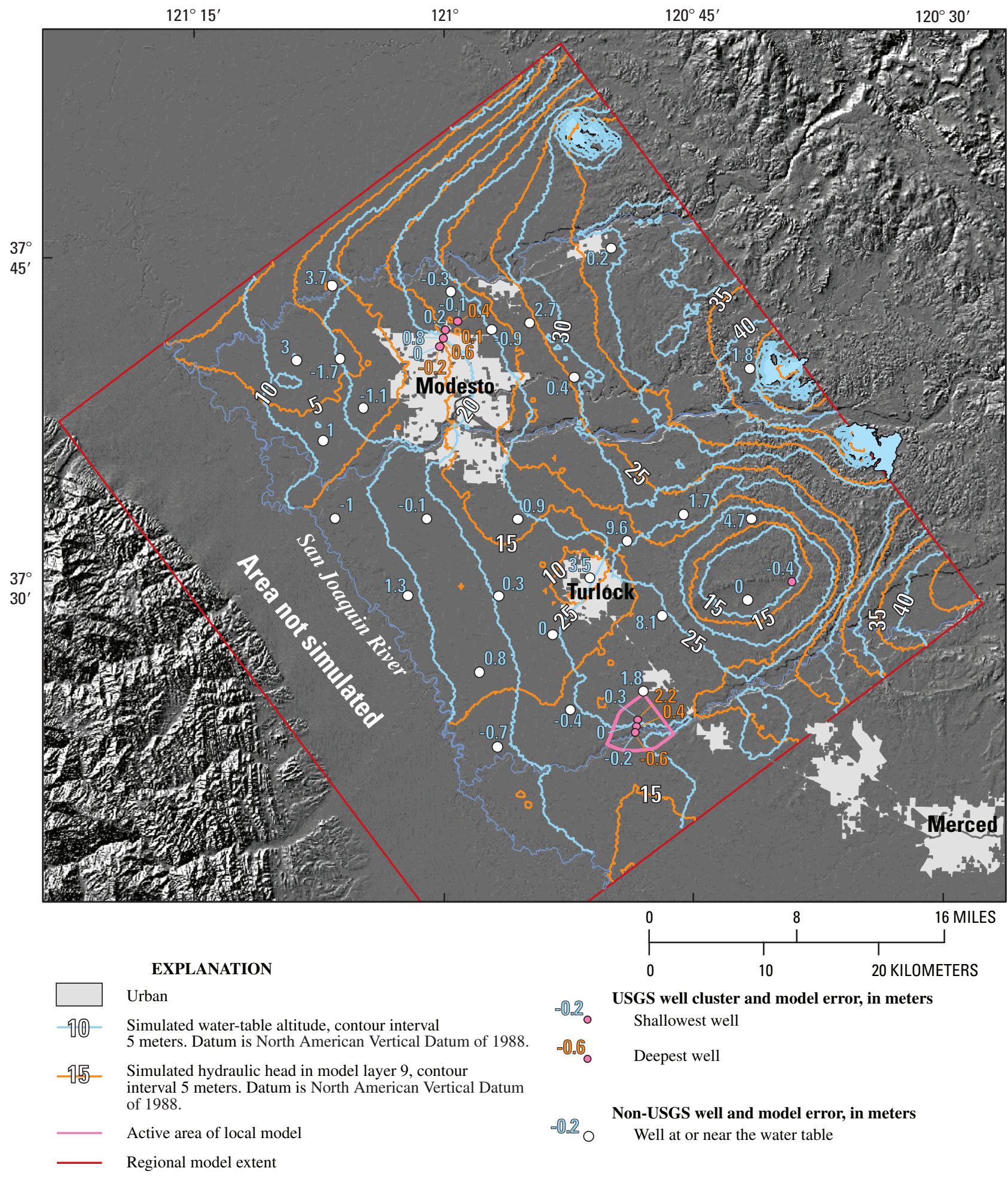

Figure 22. Simulated hydraulic heads at the water table and in layer 9 , and errors between measured water levels and simulated hydraulic heads at wells used to calibrate the regional model, San Joaquin regional study area, California. USGS, U.S. Geological Survey. 


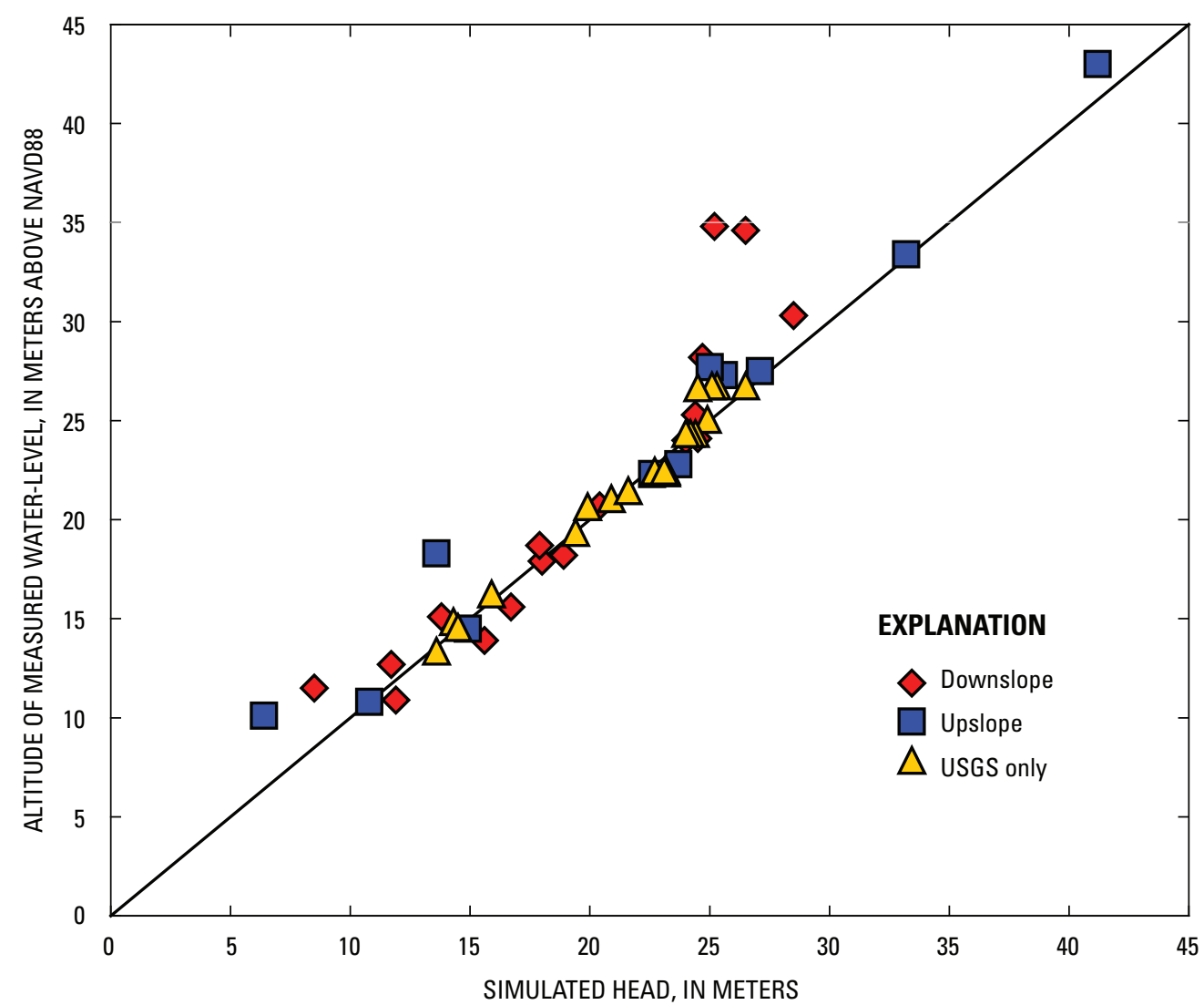

Figure 23. Relation between simulated hydraulic head and measured water levels for regional model, San Joaquin regional study area, California.

USGS, U.S. Geological Survey.

did not converge for this model, but did approach the optimal solution prior to diverging. Parameter estimation fit the water levels well, but not the vertical gradients. Hydraulic properties were adjusted manually to better match vertical gradients, which were not explicitly included in the objective function.

The calibrated hydraulic conductivity values for the local model (table 3 ) can be compared to values for a wide range of sedimentary materials and to the results from slug tests of local materials. A hydraulic conductivity of $80 \mathrm{~m} / \mathrm{d}$ is within the range typical for clean sand, and $30 \mathrm{~m} / \mathrm{d}$ is within the range for silty sand (Freeze and Cherry, 1979). Slug tests were done in 18 wells in the bed and on the banks of the Merced River down-gradient of the well transect (Zamora, 2006). The sediments tested ranged from silty sand to well-sorted coarse sand, and computed hydraulic conductivity values ranged from 15 to $250 \mathrm{~m} / \mathrm{d}$; the mean value was $85 \mathrm{~m} / \mathrm{d}$. These values are consistent with those derived by calibrating the local model.

Both hydraulic conductivity estimates for the coarsest fraction above the Corcoran Clay in the local and regional models were $80 \mathrm{~m} / \mathrm{d}$. The local calibrated value for the vertical hydraulic conductivity of clay $(0.15 \mathrm{~m} / \mathrm{d})$, however, was about an order of magnitude greater than the vertical hydraulic conductivity above the Corcoran Clay in the regional model (median of $0.012 \mathrm{~m} / \mathrm{d}$ ). Simulated vertical hydraulic gradients in the regional model within the local study area (fig. 22) were greater than those measured, suggesting that spatial variability exists in the vertical hydraulic conductivity of fine-grained materials. Lower values for the vertical hydraulic conductivity of clay in the local model increased vertical gradients above those calculated from average measured water levels, which were very small (absolute value of about $0-0.02$ ).

\section{Local Simulated Hydraulic Heads}

Figure 26 is a plot of the simulated hydraulic heads versus measured water levels for the local model and indicates excellent model fit. Average water-level measurements from 11 USGS transect wells were very closely simulated; the average error was $0.0 \mathrm{~m}$ and the RMSE was $0.08 \mathrm{~m}$. Errors ranged from -0.3 to $0.16 \mathrm{~m}$; the standard deviation was $0.17 \mathrm{~m}$. The $R M S E$ was less than 2 percent of the range of head observations in the 11 wells $(4.4 \mathrm{~m})$. The largest errors were at the middle site of the transect, ranging from $0.3 \mathrm{~m}$ near the water table (well middle_13) to $0.23 \mathrm{~m}$ at the deepest well (middle_25). All simulated heads at the middle site were greater than measured water levels. Errors at all other transect wells were less than $0.16 \mathrm{~m}$. The simulated water table is shown in figure 27. 


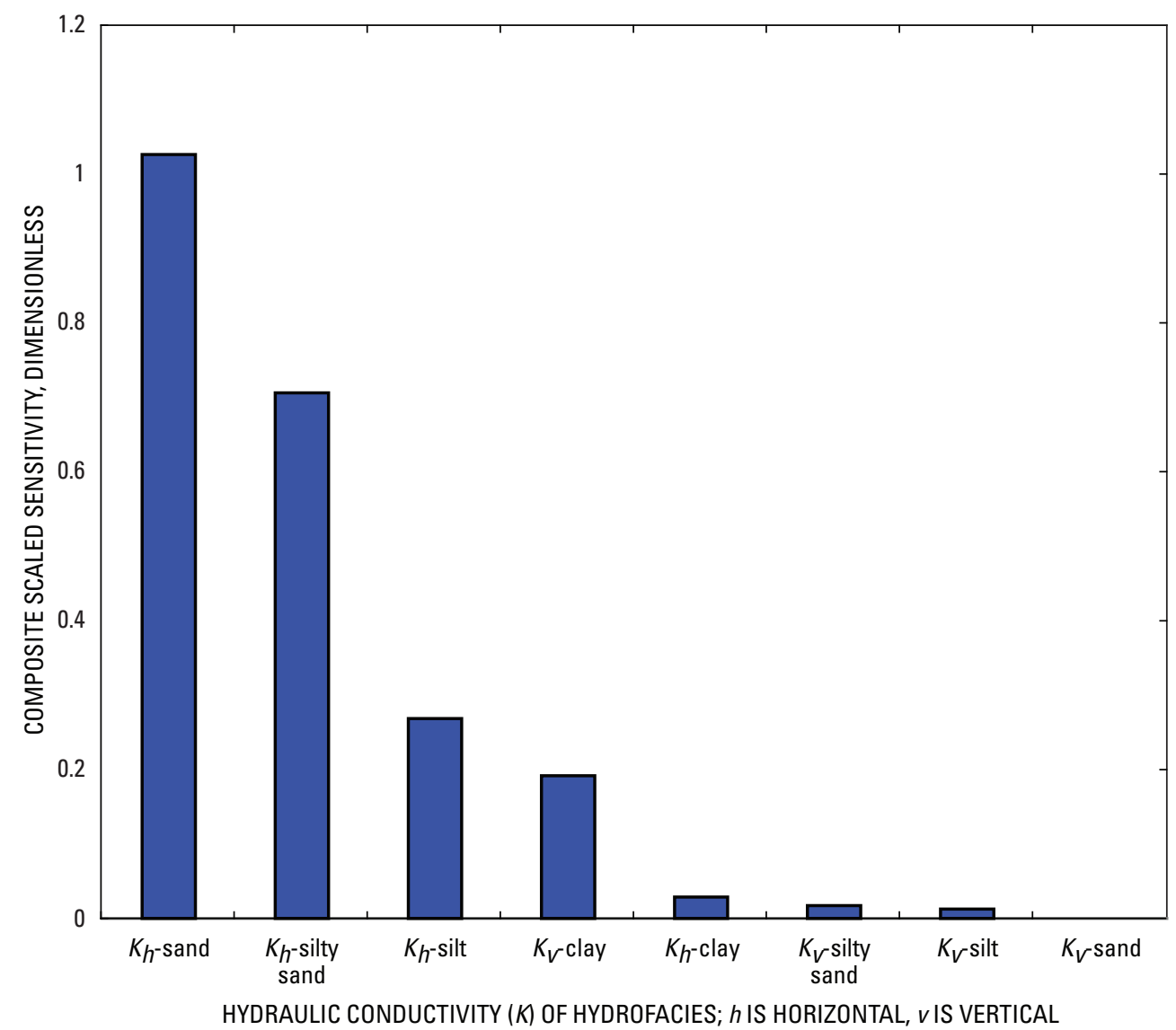

Figure 24. Relative composite sensitivity of computed hydraulic head at calibration points to changes in the horizontal and vertical hydraulic conductivities of the defined hydrofacies, local model, San Joaquin local study area, California.

Composite scaled sensitivity values are used here to show relative sensitivity; the definition and derivation are described in Hill and others (2000).

\section{Evaluation of Fluxes in Local Model}

Calibration of a model to hydraulic heads alone generally results in a non-unique set of parameters. Other parameter sets may generate roughly the same head distribution, but simulated fluxes would vary; therefore, it is useful to evaluate headbased calibrations using some measure of system flux. An environmental tracer, sulfur hexafluoride, was used to evaluate the fluxes in the calibrated local model. Areal recharge and boundary fluxes were specified in the local model, and consequently the internal fluxes were highly constrained. Thus, the following analysis was more effective in this case as a check on the specified fluxes than as a means for evaluating hydraulic parameters.

Samples collected from most of the USGS wells along the transect in the local study area were analyzed for sulfur hexafluoride $\left(\mathrm{SF}_{6}\right)$, generally a non-reactive, conservative environmental tracer in ground water (Busenberg and Plummer, 2000). Atmospheric concentrations of $\mathrm{SF}_{6}$ were very low prior to 1965 and have increased since then, making it a good means of dating young ground water. Particle-tracking software, MODPATH (Pollock, 1994), was used in conjunction with flux output from the local flow model to calculate backward flow paths and associated travel times for water particles traveling back in time from the screened intervals of sampled wells to the water table. The travel time for each particle (64 per well screen, represented by one model cell) represented only the advective component of flow, but included the effects of macro-scale mechanical dispersion caused by the three-dimensional distribution of hydrofacies.

Effective porosity was the only hydraulic parameter specified in the MODPATH input files. Effective porosity values were assigned on the basis of the hydrofacies represented by each model cell. Sand, silty sand, silt, and clay were assigned effective porosities of $0.3,0.35,0.38$, and 0.4 , respectively. These porosity values were based on literature values for different geologic/textural materials (Domenico and Schwartz, 1990), previous studies of similar geologic formations in the eastern San Joaquin Valley (Burow and others, 1999), and measurements made using sediment cores collected during the installation of the transect wells. Four cores that averaged 89 percent sand had moisture contents ranging from 


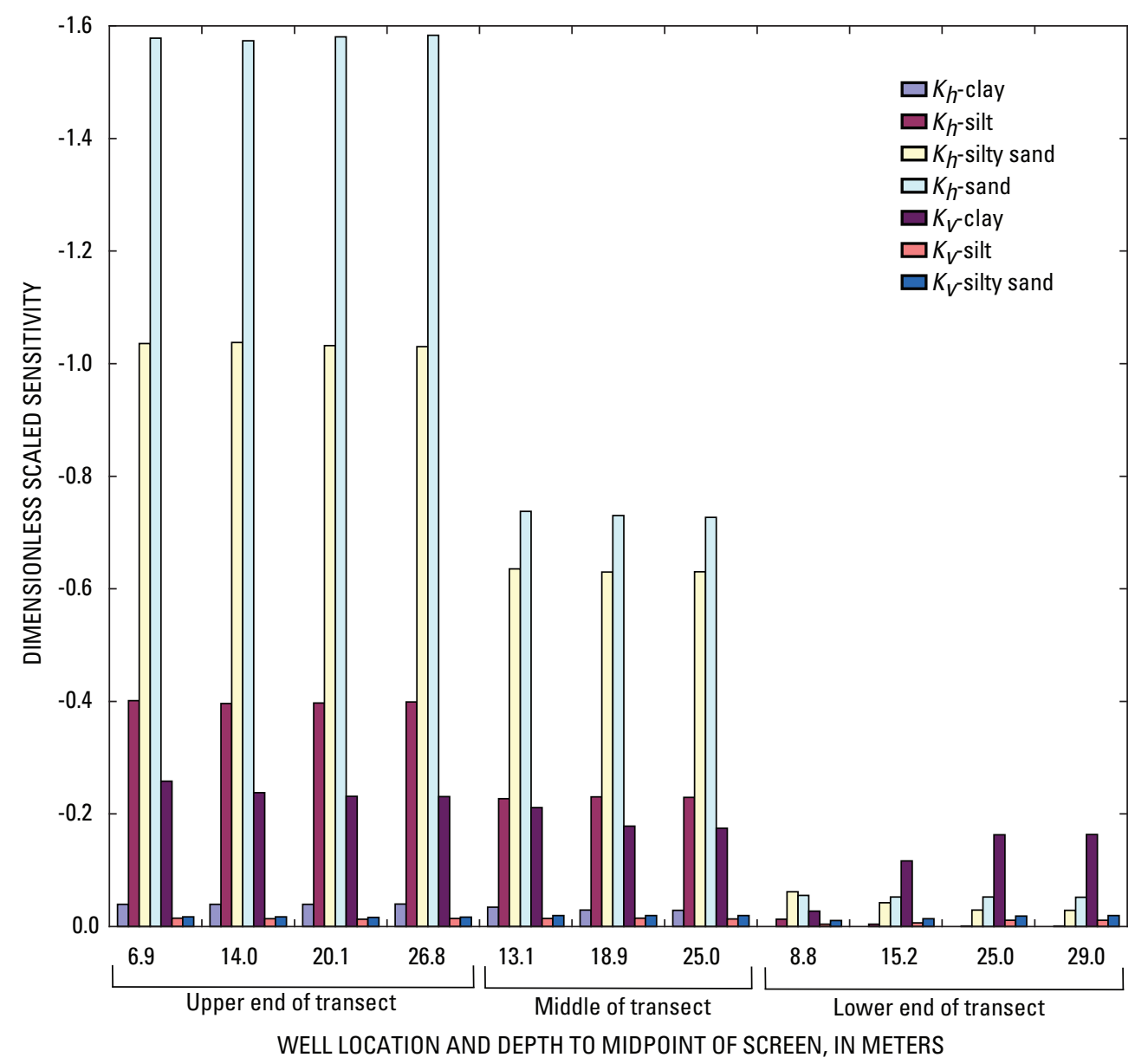

Figure 25. Relative sensitivity of computed hydraulic head at calibration points to changes in hydraulic parameters, local model, San Joaquin local study area, California.

Dimensionless scaled sensitivity values are used here to show relative sensitivity; the definition and derivation are described in Hill and others (2000).

32 to 37 percent, and a single core consisting of 83 percent silt had a moisture content of 48 percent. Effective porosity is a lower value than moisture content, and the difference between them increases with increasing content of fine-grained materials; thus, the estimated effective porosities are consistent with those measured in the local study area.

The travel time for each particle was used to determine the atmospheric concentration of $\mathrm{SF}_{6}$ when the particle was at the water table. Assuming conservative transport and steadystate conditions, the average atmospheric concentration of $\mathrm{SF}_{6}$ associated with all particles for a given well screen can be compared with the measured concentration in the well (table 4). Simulated concentrations at or near the water table are higher (younger age) than those measured at all sites, but concentrations at depth generally compare well. The cause of the disparity in shallow concentrations is unknown, but the good agreement between simulated and measured $\mathrm{SF}_{6}$ concentrations deeper in the system suggests that fluxes, which are largely controlled by specified recharge and boundary conditions, are reasonably simulated.

\section{Sensitivity of Local Model Parameter Estimates to Hydrofacies Distribution and Recharge}

The calibrated hydraulic conductivities for the local model (table 3) were based on one of 200 realizations of the three-dimensional distribution of hydrofacies. The sensitivity of parameters to their distribution was determined using four end-member realizations. These end members represented the minimum and maximum effective three-dimensional hydraulic conductivity and domain-scale vertical anisotropy. Each realization was upscaled into the regional model, which was then used to generate a new set of specified fluxes for the lateral boundaries of the local model. The local model, with each realization incorporated, was then re-calibrated until the total error approached that of the calibrated model, if feasible. Generally, this was accomplished through changes in only the most sensitive horizontal (sand) and vertical (clay) hydraulic conductivities. 


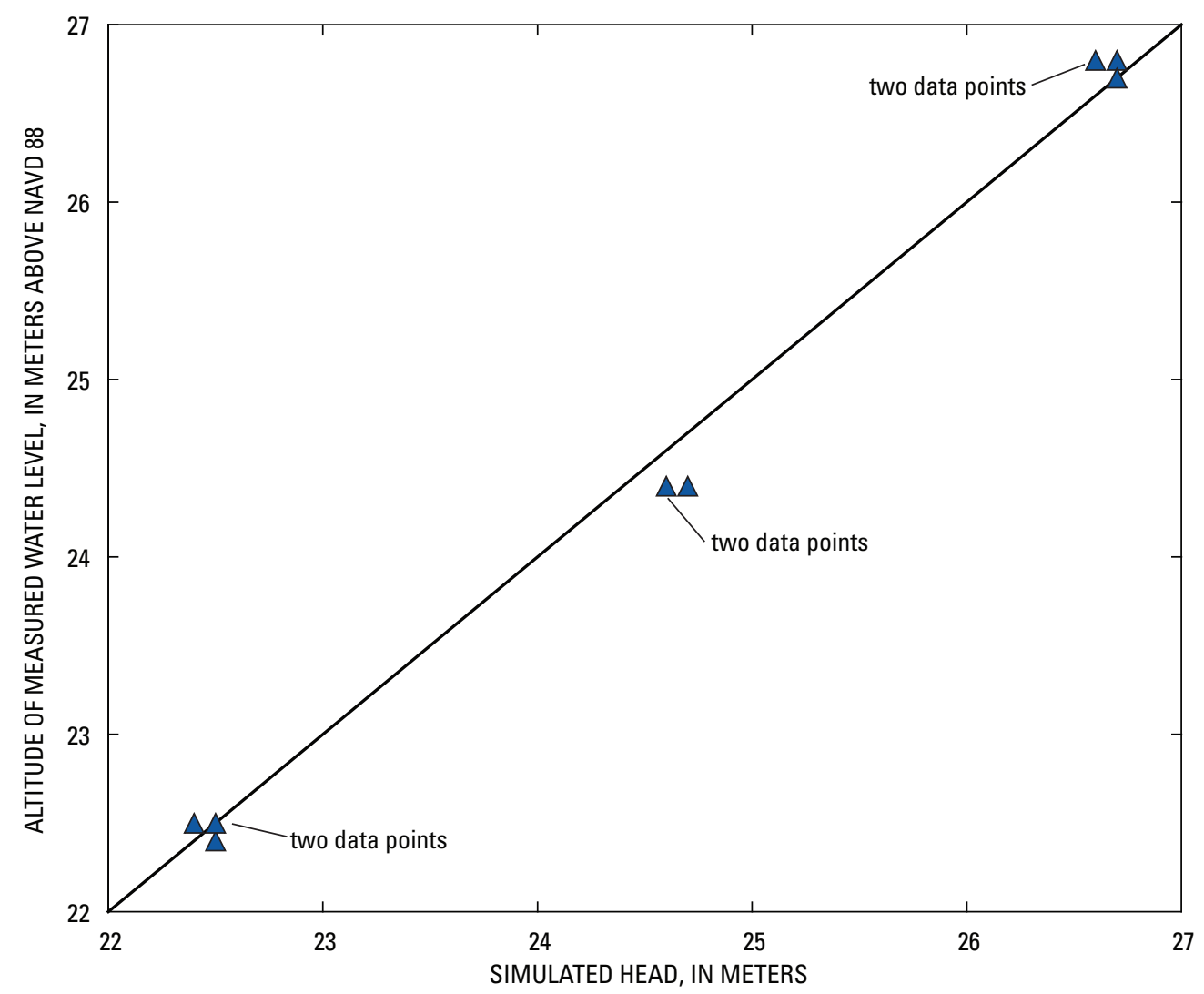

Figure 26. Relation between simulated hydraulic head and measured water levels for the local model, San Joaquin local study area, California.

The sensitivity of key hydraulic conductivity parameter estimates to the three-dimensional distribution of hydraulic conductivity is shown in table 5 . All but one realization required adjustment of only the horizontal hydraulic conductivity of sand to achieve nearly the same error as the calibrated model. These adjustments ranged from a reduction of 25 percent to an increase of 12.5 percent. The realization representing minimum domain-scale vertical anisotropy required a threefold decrease in the vertical hydraulic conductivity of clay and was associated with relatively high error. Adjustments of other hydraulic conductivity values failed to reduce the error for this realization, suggesting that model performance decreases below a minimum threshold for vertical anisotropy. This analysis indicates that if this threshold is met, the overall sensitivity of hydraulic conductivity parameter estimates to the distribution of hydrofacies is fairly low.

The sensitivity of parameter estimates for the local model to areal recharge was determined by increasing and reducing recharge by 20 percent, a quantity that would represent substantial error in the water budget. The local model was re-calibrated by adjusting the horizontal hydraulic conductivity of sand and vertical hydraulic conductivity of clay, achieving a total error within 13 percent of that of the calibrated model. Reducing recharge by 20 percent required a 50 -percent reduction in the conductivity of sand. A 20-percent increase in recharge required increasing the hydraulic conductivity of sand by 38 percent and doubling the hydraulic conductivity of clay. This analysis shows that the sensitivity of hydraulic parameter estimates to large changes in areal recharge, which represents 76 percent of the total recharge, is moderate.

The effects of changes in the hydrofacies distribution and areal recharge rates on the simulated water budget were straightforward. Small changes in net boundary fluxes related to hydrofacies distribution, and large changes in areal recharge rates, were balanced by like changes in discharge to the Merced River. 


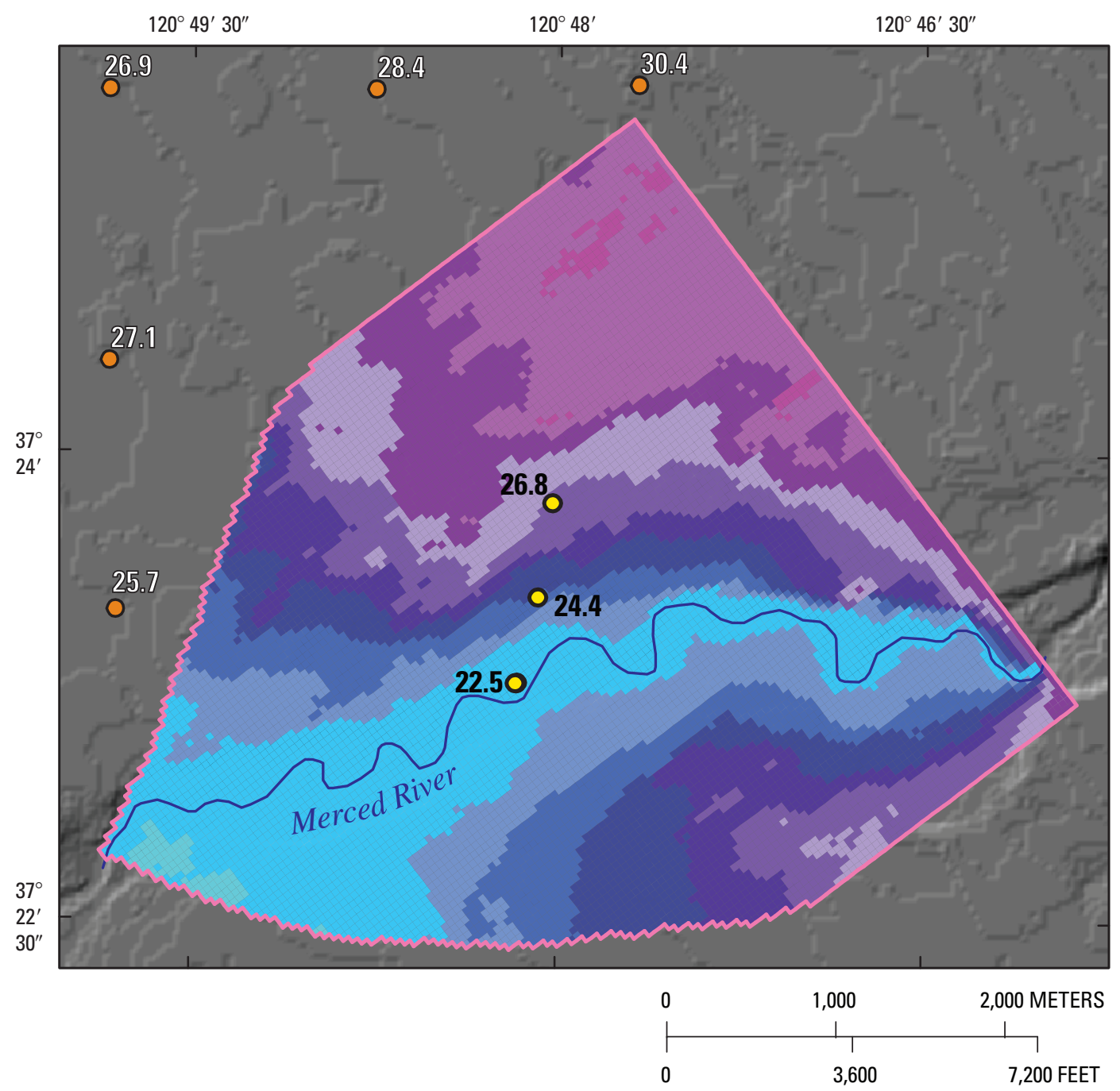

EXPLANATION

Simulated water-table altitude, in meters

21 to 22

22 to 23

\begin{tabular}{|c|}
\hline 27 to 28 \\
\hline 28 to 29 \\
\hline 29 to 30 \\
\hline 30 to 31 \\
\hline 31 to 32 \\
\hline
\end{tabular}

23 to 24

24 to 25

25 to 26

26 to 27
Active area of local model
22.5 USGS well cluster along transect and average measured
O water table altitude, 2004-2005, in meters. Datum is North American Vertical Datum of 1988.
25.7 Water-table well measured monthly by the Turlock
O Irrigation District, and average monthly water-table altitude for water year 2000, in meters. Datum is North American Vertical Datum of 1988.

Figure 27. Simulated water-table altitudes for the local model, San Joaquin local study area, California. 
Table 4. Measured concentrations of sulfur hexafluoride $\left(\mathrm{SF}_{6}\right)$ along the U.S. Geological Survey well transect and concentrations estimated using simulated travel time and historical atmospheric concentrations of $\mathrm{SF}_{6^{\prime}}$ San Joaquin local study area, California.

[m, meter; yr, year; pptv, parts per trillion by volume]

\begin{tabular}{|c|c|c|c|c|c|c|c|c|}
\hline \multirow{3}{*}{$\begin{array}{c}\text { Location of well on } \\
\text { transect }\end{array}$} & \multirow{3}{*}{$\begin{array}{c}\text { Midpoint of } \\
\text { screen below } \\
\text { land surface (m) }\end{array}$} & \multicolumn{3}{|c|}{ Simulated travel time (yr) } & \multicolumn{4}{|c|}{ Concentrations of $\mathrm{SF}_{6}$ (pptv) } \\
\hline & & \multirow{2}{*}{ Median } & \multirow{2}{*}{ Maximum } & \multirow{2}{*}{ Minimum } & \multirow{2}{*}{ Estimated } & \multicolumn{3}{|c|}{ Measured } \\
\hline & & & & & & Average & Maximum & Minimum \\
\hline Upper end & 7 & 0.4 & 0.5 & 0.2 & 5.7 & 4.2 & 4.6 & 3.7 \\
\hline Upper end & 27 & 12.9 & 18.5 & 11.6 & 2.6 & 2.1 & 2.5 & 1.7 \\
\hline Middle & 13 & 4.3 & 6.5 & 3.6 & 4.7 & 3.5 & 3.5 & 3.5 \\
\hline Middle & 19 & 8.9 & 12.3 & 5.8 & 3.7 & 2.5 & 2.6 & 2.3 \\
\hline Lower end & 9 & 9.1 & 19.2 & 6.2 & 3.4 & 1.1 & 1.2 & 1.0 \\
\hline Lower end & 15 & 20.5 & 49.3 & 11.4 & 1.5 & 1.4 & 1.7 & 1.0 \\
\hline Lower end & 25 & 23.6 & 104.0 & 17.6 & 0.9 & 0.4 & 0.4 & 0.3 \\
\hline Lower end & 29 & 39.9 & 135.5 & 1.0 & 1.1 & 0.6 & 0.7 & 0.4 \\
\hline
\end{tabular}

Table 5. Changes in key hydraulic conductivity parameters with alternate three-dimensional distributions of hydrofacies in the local model, San Joaquin local study area, California.

[m/d, meter per day; m, meter]

\begin{tabular}{|c|c|c|c|c|c|}
\hline \multirow{3}{*}{$\begin{array}{l}\text { Hydrofacies and direction of } \\
\text { hydraulic conductivity }\end{array}$} & \multicolumn{5}{|c|}{ Hydraulic conductivity for realizations of hydrofacies distribution } \\
\hline & \multirow{2}{*}{$\begin{array}{l}\text { Calibrated } \\
\text { model }\end{array}$} & \multicolumn{2}{|c|}{$\begin{array}{c}\text { Effective hydraulic } \\
\text { conductivity }\end{array}$} & \multicolumn{2}{|c|}{$\begin{array}{c}\text { Domain-scale vertical } \\
\text { anisotropy }\end{array}$} \\
\hline & & Maximum & Minimum & Maximum & Minimum \\
\hline Sand, horizontal (m/d) & 80 & 60 & 90 & 70 & 80 \\
\hline Clay, vertical $(\mathrm{m} / \mathrm{d})$ & 0.15 & 0.15 & 0.15 & 0.15 & 0.05 \\
\hline Sum of squared residuals (m) & 0.27 & 0.37 & 0.1 & 0.31 & 1.1 \\
\hline
\end{tabular}

\section{Model Results}

The simulated water budget for the regional-scale model is presented in table 6 . Note that many of the water-budget components of the regional model were specified values. Areal recharge was mostly agricultural irrigation and precipitation, accounting for 80 percent of the total recharge; urban recharge added another 1 percent to the total. Areal recharge estimates were reduced from those of Burow and others (2004) by 10 percent during calibration, but remain the dominant component of recharge. Leakage from reservoirs contributed about 4 percent of the recharge, and the rivers less than 1 percent (net). Pumpage from wells, primarily for agriculture, was about 70 percent of the total discharge. About 6 percent of the discharge was bare-soil evaporation from the shallow water table. The remainder of the simulated water budget was flow through the lateral head-dependent boundaries, which was about a net 8-percent export.

Flow through the lateral boundaries is different at each boundary. The northern boundary is dominated by northward flow above and below the Corcoran Clay, exiting the regional study area. This is consistent with the limited avail- able water-level data for the area north of the Stanislaus River (fig. 8). This northward flow is 13 percent of the simulated budget, more than twice the flow at any other lateral boundary. The southern boundary is characterized by flow entering the regional model and moving toward the Merced River above the Corcoran Clay, and exiting below the clay and at depth east of the clay. Flow is in the opposite sense along the western boundary, exiting the model area above the Corcoran Clay, and entering from below. The southern boundary and the western boundary each have a simulated net flux into the regional model domain that comprises only $1-2$ percent of the total water budget.

The simulated water budget for the local-scale model is given in table 7. Note that most of the water-budget components of the local model were specified values. Areal recharge, which was dominated by agricultural irrigation and precipitation, accounted for 76 percent of the total recharge. Discharge was dominated by flow to the Merced River ( 65 percent), and included downward flow through the Corcoran Clay (16 percent). The remainder of the simulated water budget was flow through the lateral specified-flux boundaries, which was a net 5-percentage gain. 
Table 6. Simulated water budget for the regional model, San Joaquin regional study area, California.

[Values are cubic meters per day]

\begin{tabular}{lrrr}
\hline Recharge from & Specified & Computed & Percent $^{1}$ \\
\hline Irrigation return & $1,997,000$ & & 46.9 \\
Precipitation & $1,409,000$ & & 33.1 \\
Urban, all sources & 41,000 & & 1.0 \\
Reservoir leakage & & 155,000 & 3.7 \\
Rivers & 105,000 & 10,000 & 2.7 \\
Flow through lateral boundaries & & & \\
$\quad$ Northern & & 44,000 & 1.0 \\
$\quad$ Southern & & 243,000 & 5.7 \\
$\quad$ Western & & & 6.0 \\
& & & \\
\hline Discharge to & $2,655,000$ & \\
\hline Wells & 294,000 & & 63.3 \\
$\quad$ Agricultural & & 7.0 \\
$\quad$ Urban & & 867,000 & 6.4 \\
Evaporation from shallow water table & & & \\
Rivers & & 547,000 & 13.0 \\
Flow through lateral boundaries & & 162,000 & 3.9 \\
$\quad$ Northern & & & \\
$\quad$ Southern & & & \\
Western & & & \\
\hline
\end{tabular}

${ }^{1}$ Totals do not add to 100 because of rounding.

Table 7. Simulated water budget for the local model, San Joaquin local study area, California.

[Values are cubic meters per day]

\begin{tabular}{|c|c|c|c|}
\hline Recharge from & Specified & Computed & Percent $^{1}$ \\
\hline Irrigation return & 14,300 & & 51.3 \\
\hline Precipitation & 7,000 & & 25.0 \\
\hline Rivers & & 0 & 0.0 \\
\hline \multicolumn{4}{|l|}{ Flow through lateral boundaries } \\
\hline Northwest & 700 & & 2.5 \\
\hline Southeast & 3,500 & & 12.7 \\
\hline Southwest & 2,400 & & 8.5 \\
\hline Flow through Corcoran Clay & & 0 & 0.0 \\
\hline \multicolumn{4}{|l|}{ Discharge to } \\
\hline Rivers & & 17,700 & 64.6 \\
\hline \multicolumn{4}{|l|}{ Flow through lateral boundaries } \\
\hline Northwest & 3,000 & & 11.1 \\
\hline Southeast & 40 & & 0.2 \\
\hline Southwest & 2,100 & & 7.7 \\
\hline Flow through Corcoran Clay & & 4,500 & 16.5 \\
\hline
\end{tabular}

${ }^{1}$ Totals do not add to 100 because of rounding. 
The dominance of areal recharge and discharge to the Merced River results in downward flow in most of the local study area and upward flow along the Merced River, which is consistent with measured water levels along the well transect. This flow configuration, coupled with downward flow through the Corcoran Clay, results in primarily locallyrecharged ground water discharging to the Merced River. The combination of measured sulfur hexafluoride concentrations and travel times of simulated particles (table 4) suggests that most of the ground water discharging to the Merced River was recharged less than 25 years ago.

\section{Limitations and Appropriate Use of the Models}

The regional and local ground-water flow models were developed to generate a better understanding of the flow system at both scales. The local model will be used to help understand the transport and fate of agricultural chemicals in the local study area. Limitations of the modeling software, assumptions made during model development, and results of model calibration and sensitivity analysis all are factors that constrain the appropriate use of these models and highlight potential future improvements.

A ground-water flow model is a means for testing a conceptual understanding of a system. Because ground-water flow systems are inherently complex, simplifying assumptions were made in developing and applying model codes (Anderson and Woessner, 1992). Models solve for average conditions within each cell, the parameters for which are interpolated or extrapolated from measurements, and (or) estimated during calibration. In light of this, the intent in developing the regional and local ground-water flow models was not to reproduce every detail of the natural system, but to portray its general characteristics. Results from these models should be interpreted generally and are best suited for comparative analysis rather than for prediction.

A steady-state model portrays a system that is in equilibrium. Although water-level hydrographs suggest this generally was the case in the regional study area for the year 2000 (fig. 9), the data were not conclusive. Long-term hydrographs are not available for some areas, including the southeastern part of the model area, where hydraulic heads may have been changing with time. There are no long-term water-level records available in the local model area, but the closest wells show little change in about 40 years of record. Errors related to the assumption of a steady-state condition may be significant in places, and care must be taken in interpreting model results and analyses that depend on model output, including particle tracking.

A problem related to the steady-state assumption for both models was that stresses were based on data from water year 2000, but the water levels for USGS wells were measured during 2003-2005. Although this may be a source of model error, none of these years represented climatic aberrations. It is likely that deliveries of surface water for agricultural and urban use, and associated ground-water pumpage, varied little during these years.

\section{Regional Model}

Some of the boundary conditions of the regional model were poorly constrained, which may be a source of model error. The western and northern lateral boundaries were based on sparse data; the spatial distribution of hydraulic head below the river was poorly understood, and there were no available data in the western part of the northern area. Similarly, there was little regional information on river-aquifer interaction and the hydraulic conductivity of riverbed sediments. Simulation results indicated that flows across these poorly constrained boundaries (table 6) generally made up a small part of the water budget; however, this may not be true in the real system.

The accuracy of model results is related strongly to the quality and spatial distribution of input data and of measurements of system state (for example, measured water levels) used to constrain the calibration. The local study area and the Modesto area were the only locations in the regional model that had high-quality input data, including pumpage by well and sediment texture, coupled with a good distribution of high-quality water-level measurements. The stresses in other areas of the model were a combination of measured values and values estimated from the water-budget analysis. Accordingly, the user should have more confidence in simulation results in the local study area and the Modesto area than in other parts of the model.

The regional estimate of the vertical hydraulic conductivity of fine-grained materials was about one order of magnitude lower than that estimated at the local scale. Simulated vertical hydraulic gradients are more accurate (smaller) in the local model than in the regional model within the local study area (figs. 27, 22). This suggests that there may be substantial spatial variability in the vertical hydraulic conductivity of fine-grained materials that is not accounted for in the regional model.

\section{Local Model}

The specified areal recharge and lateral boundary conditions in the local model, which account for all of the simulated recharge, highly constrain the internal fluxes. This, in turn, constrains the range of estimated hydraulic conductivities. Key hydraulic conductivity values are sensitive to substantial changes in areal recharge; rates of chemical transport are expected to be equally sensitive. In contrast, these key hydraulic conductivity values, and associated fluxes, are less sensitive to the three-dimensional distribution of the four defined hydrofacies.

All of the water-level data used to calibrate the local model were collected from USGS transect wells, which are concentrated in the central part of the model domain. Accordingly, the user should have higher confidence in simulation results for the area near the well transect than for other areas represented in the model. 


\section{Summary}

Regional and local models of ground-water flow in the northeastern San Joaquin Valley were developed as part of a study of the transport and fate of agricultural chemicals by the U.S. Geological Survey's (USGS) National Water-Quality Assessment Program. The northeastern San Joaquin Valley, near the city of Modesto, is a semi-arid region dominated by irrigated agriculture. The aquifer system is predominantly alluvial. An unconfined to semiconfined aquifer overlies a confined aquifer in the southwestern part of the study area; these aquifers are separated by the lacustrine Corcoran Clay. Ground water is a key source of water for irrigation and public supply, and exploitation of this resource has altered the natural flow system. Primarily lateral flow from the mountain front to the San Joaquin River has been overprinted with downward flow driven by enhanced recharge from irrigation and discharge from irrigation pumpage.

A regional-scale, 16-layer steady-state model of groundwater flow in the unconfined to confined aquifer system underlying the Modesto area was developed to provide boundary conditions for an embedded 110-layer steady-state local-scale model of part of the aquifer system overlying the Corcoran Clay along the Merced River. The purpose of the local-scale model was to develop a better understanding of the aquifer system and to provide a basis for simulating reactive transport of agricultural chemicals.

Lateral boundary conditions for the regional model were no-flow along the Sierra Nevada foothills and general-head elsewhere. The water table was a free surface, and the lower boundary, far below the depth of wells, was no-flow. Recharge and agricultural pumpage were estimated using a water-budget approach, and bare-soil evaporation was simulated where the water table was shallow. Agricultural pumpage and recharge from irrigation return flow were the dominant components of the simulated water budget for the regional model.

Lateral boundary conditions for the local model, embedded within the regional, were specified fluxes from the regional model. The upper boundary was a free surface, and the lower boundary was general-head, allowing flow through the Corcoran Clay. Recharge from irrigation return flow was estimated on the basis of crop type and irrigation method for each field. Ground water generally was not used in the local model area. The dominant components of the simulated local budget were recharge from irrigation return flow and discharge to the Merced River.

The heterogeneity of aquifer materials was explicitly incorporated into the regional and local models using information from geologic and drillers' logs of boreholes. Aquifer materials were differentiated in the regional model by the percentage of coarse-grained sediments in a cell. This percentage was estimated for most cells in the model by three-dimensional kriging and by downward extrapolation where kriging did not generate a value owing to data scarcity. Aquifer materials were differentiated in the local model by four hydrofacies (sand, silty sand, silt, and clay). Multiple realizations of the distribution of these hydrofacies were estimated using a transition-probability geostatistical technique that honored highquality geologic logs and was conditionally influenced by data from drillers' logs.

Different calibration methods were used for the regional and the local models. The regional model was calibrated by exploring a range of end-member coarse- and fine-grained hydraulic conductivities used to generate horizontal and vertical conductivities for each cell using texture-weighted arithmetic and harmonic means, respectively. The local model was calibrated primarily using the parameter estimation capabilities within MODFLOW-2000.

The calibrated horizontal hydraulic conductivities of the coarse-grained materials in the zone above the Corcoran Clay in the regional model and of the sand hydrofacies of the local model were about equal (30-80 m/d [meter per day]). The vertical hydraulic conductivity of the same zone in the regional model (median of $0.012 \mathrm{~m} / \mathrm{d}$ ), which is dominated by the finer-grained materials, was about an order of magnitude less than that for the clay hydrofacies in the local model.

Data used for calibration of both models included longterm hourly water-level measurements in 20 short-screened wells installed by the USGS in the Modesto and the Merced River areas. Additional data used for calibrating the regional model included water-level measurements in 11 wells upslope and 17 wells downslope from these areas. The root mean square error was $2.3 \mathrm{~m}$ (meter) for all wells in the regional model and $0.8 \mathrm{~m}$ for the USGS wells; the associated average errors were $0.9 \mathrm{~m}$ and $0.3 \mathrm{~m}$, respectively. The root mean square error for the 12 USGS wells in the local model area was $0.08 \mathrm{~m}$; the average error was $0 \mathrm{~m}$. Particle tracking was used for the local model to estimate the concentration of an environmental tracer, sulfur hexafluoride, in 10 USGS wells near the Merced River that were sampled for this constituent. Measured and estimated concentrations in the mid-depth and deepest wells, those most sensitive to errors in hydraulic conductivity estimates, were consistent. The combined results of particle tracking and sulfur hexafluoride analysis suggest that most water sampled from the transect wells was recharged less that 25 years ago.

\section{Acknowledgments}

Many individuals and organizations aided this study through contributions of data and technical expertise. The authors gratefully acknowledge the helpful contributions from Walter Ward, Joseph Lima, and others from the Modesto Irrigation District; Debbie Liebersbach from the Turlock Irrigation District; and many others from various water purveyors in the study area. Special thanks go to the landowners who allowed us to drill wells and install other monitoring equipment on their land. Leon Kauffman, USGS, generously offered his technical expertise, and for that we are very grateful. 


\section{References}

Anderson, M.P. and Woessner, W.W., 1992, Applied groundwater modeling - Simulation of flow and advective transport: San Diego, Calif., Academic Press, Inc., 381 p.

Arkley, R.J., 1962, Soil survey of Merced area, California: U.S. Department of Agriculture, Soil Conservation Service, Soil Survey series 1950, no. 7, 131 p., 101 pls.

Arkley, R.J., 1964, Soil survey, eastern Stanislaus area, California: U.S. Department of Agriculture, Soil Conservation Service, Soil Survey series 1957, no. 20, 160 p.

Bartow, J.A., 1991, The Cenozoic evolution of the San Joaquin Valley, California: U.S. Geological Survey Professional Paper 1501, 40 p.

Belitz, Kenneth, and Phillips, S.P., 1995, Alternative to agricultural drains in California's San Joaquin ValleyResults of a regional-scale hydrogeologic approach: Water Resources Research, v. 31, no. 8, p. 1845-1862.

Böhlke, J.K., 2005, C. Tracermodel1. Excel workbook for calculation and presentation of environmental tracer data for simple groundwater mixtures, in International Atomic Energy Agency guidebook on the use of chlorofluorocarbons in hydrology: Vienna, International Atomic Energy Agency, p. 202-206.

Burow, K.R., Panshin, S.Y., Dubrovsky, N.M., Van Brocklin, David, and Fogg, G.E., 1999, Evaluation of processes affecting 1,2-dibromo-3-chloropropane (DBCP) concentrations in ground water in the eastern San Joaquin Valley, California: Analysis of chemical data and ground-water flow and transport simulations: U.S. Geological Survey Water-Resources Investigations Report 99-4059, 57 p.

Burow, K.R., Shelton, J.L., Hevesi, J.A., and Weissmann, G.S., 2004, Hydrogeologic characterization of the Modesto area, San Joaquin Valley California: U.S. Geological Scientific Investigations Report 2004-5232, 54 p.

Busenberg, E., and Plummer, L.N., 2000, Dating young groundwater with sulfur hexafluoride-Natural and anthropogenic sources of sulfur hexafluoride: Water Resources Research, v. 36, n. 10, p. 3011-3030.

California Department of Water Resources, 2001a, Land use for Merced County, California, for 1995 [digital data]: California Department of Water Resources, Division of Planning, Statewide Planning Branch, Land and Water Use.

California Department of Water Resources, 2001b, Land use for San Joaquin and Stanislaus Counties, California, for 1996 [digital data]: California Department of Water Resources, Division of Planning, Statewide Planning Branch, Land and Water Use.
California Department of Water Resources, 1994, Urban water use in California, Bulletin 166-4: California Department of Water Resources, 48 p. plus appendixes.

Carle, S.F., 1996, A transition probability-based approach to geostatistical characterization of hydrostratigraphic architecture: University of California, Davis, PhD Dissertation, $182 \mathrm{p}$.

Carle, S.F., 1997, Implementation schemes for avoiding artifact discontinuities in simulated annealing: Mathematical Geology, 29, p. 231-244.

Carle, S.F., and Fogg, G.E., 1996, Transition probability-based indicator geostatistics: Mathematical Geology, v. 28, no. 4, p. 453-477.

Carle, S.F., and Fogg, G.E., 1997, Modeling spatial variability with one and multidimensional continuous-lag Markov chains: Mathematical Geology, v. 29, no. 2, p. 891-917.

Carle, S.F., LaBolle, E.M., Weissmann, G.S., VanBrocklin, D. and Fogg, G.E., 1998, Conditional simulation of hydrostratigraphic architecture: a transition probability/ Markov approach, in Fraser, G.S., and Davis, J.M., (eds.), Concepts in hydrogeology and environmental geology no. I, SEPM (Society for Sedimentary Geology) special publication, p. $147-170$.

Croft, M.G., 1972, Subsurface geology of the late Tertiary and Quaternary water-bearing deposits of the southern part of the San Joaquin Valley, California: U.S. Geological Survey Water-Supply Paper 1999-H, 29 p.

Davis, G.H., Green, J.H., Olmsted, F.H., and Brown, D.W., 1959, Ground-water conditions and storage capacity in the San Joaquin Valley, California: U.S. Geological Survey Water-Supply Paper 1469, 287 p.

Davis, S.N. and Hall, F.R., 1959, Water-quality of eastern Stanislaus and northern Merced counties, California: Palo Alto, Calif., Stanford University Publications, Geological Sciences, v. 6, no. 1, 112 p.

Domenico, P.A., and Schwartz, F.W., 1990, Physical and chemical hydrogeology: New York, John Wiley and Sons, 824 p.

Eberts, S.M., Erwin, M.L., and Hamilton, P.A., 2005, Assessing the vulnerability of public-supply wells to contamination from urban, agricultural, and natural sources: U.S. Geological Survey Fact Sheet 2005-3022, 4 p.

Fenske, J.P., Leake, S.A., and Prudic, D.E., 1996, Documentation of a computer program (RES1) to simulate leakage from reservoirs using the modular finite-difference groundwater flow model (MODFLOW): U.S. Geological Survey Open-File Report 96-364, 51 p. 
Fogg, G.E., Carle, S., and Green, C.T., 2001, A connected network paradigm for the alluvial aquifer system, in Zhang, Dongxiao, and Winter, C.L., (eds.), Theory, modeling and field investigation in hydrogeology: GSA Special Publication, A Special Volume in Honor of Shlomo P. Neuman's $60^{\text {th }}$ Birthday, $252 \mathrm{p}$.

Freeze, R.A., and Cherry, J.A., 1979, Groundwater: New Jersey, Prentice-Hall, 604 p.

Gronberg, J.M., Dubrovsky, N.M., Kratzer, C.K., Domagalski, J.L., Brown, L.R., and Burow, K.R., 1998, Environmental setting of the San Joaquin-Tulare Basins, California: U.S. Geological Survey Water-Resources Investigations Report 97-4205, 45 p.

Gronberg, J.M. and Kratzer, C.R., 2006, Environmental setting of the lower Merced River Basin, California, U.S. Geological Survey Scientific Investigations Report 2006-5152, $27 \mathrm{p}$.

Harbaugh, A.W., Banta, E.R., Hill, M.C., and McDonald, M.G., 2000, MODFLOW-2000, the U.S. Geological Survey modular ground-water model-User guide to modularization concepts and the ground-water flow process: U.S. Geological Survey Open-File Report 00-92, 121 p.

Hill, M.C., Banta, E.R., Harbaugh, A.W., and Anderman, E.R., 2000, MODFLOW-2000, the U.S. Geological Survey modular ground-water model-User guide to the observation, sensitivity, and parameter-estimation processes and three post-processing programs: U.S. Geological Survey OpenFile Report 00-184, 209 p.

Laudon, J., and Belitz, Kenneth, 1991, Texture and depositional history of late Pleistocene-Holocene alluvium in the central part of the western San Joaquin Valley, California: Bulletin of the Association of Engineering Geologists, v. 28, no. 1, p. $73-88$.

Londquist, C.J., 1981, Digital model of the unconsolidated aquifer system in the Modesto Area, Stanislaus and San Joaquin counties, California: U.S. Geological Survey WaterResources Investigations Report 81-12, 36 p.

Marchand, D.E., and Allwardt, A., 1978, Preliminary geologic map showing Quaternary deposits of the northeastern San Joaquin Valley, California: U.S. Geological Survey Miscellaneous field studies, map MF-945.

Marchand, D.E., and Allwardt, A., 1981, Late Cenozoic stratigraphic units, northeastern San Joaquin Valley, California: U.S. Geological Survey Bulletin 1470, 70 p.

National Oceanic and Atmospheric Administration, 2005, California precipitation data, accessed November 14, 2005, at $h t t p: / / l w f . n c d c . n o a a . g o v / o a / p u b / d a t a / c o o p-p r e c i p / c a l i f o r-$ nia.txt.
Page, R.W., 1977, Guide for data collection to calibrate a predictive digital ground-water model of the unconfined aquifer in and near the city of Modesto, California: U.S. Geological Survey Water-Resources Investigations Report 76-41, $46 \mathrm{p}$.

Page, R.W., 1986, Geology of the fresh ground-water basin of the Central Valley, California with texture maps and sections: U.S. Geological Survey Professional Paper 1401-C, $54 \mathrm{p}$.

Page, R.W., and Balding, G.O., 1973, Geology and quality of water in the Modesto-Merced area, San Joaquin Valley, California: U.S. Geological Survey Water-Resources Investigations Report 73-6, 85 p.

Phillips, S.P., Beard, Sherrill, and Gilliom, R.J., 1991, Quantity and quality of ground-water inflow to the San Joaquin River, California: U.S. Geological Survey Water-Resources Investigations Report 91-4019, 64 p.

Phillips, S.P. and Belitz, Kenneth, 1991, Calibration of a texture-based model of a ground-water flow system, western San Joaquin Valley, California: Ground Water, v. 29, no. 5, p. $702-715$.

Phillips, S.P., Burow, K.R., Rewis, D.L., Shelton, Jennifer, and Jurgens, Bryant, in press, Chapter D: Hydrogeologic settings and ground-water flow simulations of the San Joaquin large-spatial-scale study area, California, in Paschke, S.S., ed., Hydrogeologic settings and ground-water flow simulations for regional studies of the transport of anthropogenic and natural contaminants to public-supply wells-Studies began in 2001: U.S. Geological Survey Professional Paper 1737-A.

Piper, A.M., Gale, H.S., Thomas, H.E., and Robinson, T.W., 1939, Geology and ground-water hydrology of the Mokelumne area, California: U.S. Geological Survey Water-Supply Paper 780, $230 \mathrm{p}$.

Pollock, D.W., 1994, Source code and ancillary data files for the MODPATH particle tracking package of the groundwater flow model MODFLOW; version 3, release 1: U.S. Geological Survey Open-File Report 94-0463, 6 p., 2 diskettes.

Williamson, A.K., Prudic, D.E., and Swain, L.A., 1989, Ground-water flow in the Central Valley, California: U.S. Geological Survey Professional Paper 1401-D, 127 p.

Zamora, C., 2006, Estimating rates of exchange across the sediment/water interface in the lower Merced River, CA: California State University, Sacramento, M.S. thesis, 110 p. 

Printed on recycled paper 